\title{
Mountain top eco-industrial park: An eco-industrial, renewable energy approach for industrial park development
}

Jing Chu

West Virginia University

Follow this and additional works at: https://researchrepository.wvu.edu/etd

\section{Recommended Citation}

Chu, Jing, "Mountain top eco-industrial park: An eco-industrial, renewable energy approach for industrial park development" (2014). Graduate Theses, Dissertations, and Problem Reports. 143.

https://researchrepository.wvu.edu/etd/143

This Thesis is protected by copyright and/or related rights. It has been brought to you by the The Research Repository @ WVU with permission from the rights-holder(s). You are free to use this Thesis in any way that is permitted by the copyright and related rights legislation that applies to your use. For other uses you must obtain permission from the rights-holder(s) directly, unless additional rights are indicated by a Creative Commons license in the record and/ or on the work itself. This Thesis has been accepted for inclusion in WVU Graduate Theses, Dissertations, and Problem Reports collection by an authorized administrator of The Research Repository @ WVU. For more information, please contact researchrepository@mail.wvu.edu. 


\title{
Mountain Top Eco-Industrial Park: \\ An Eco-industrial, Renewable Energy Approach for Industrial \\ Park Development
}

\author{
Jing Chu
}

\begin{abstract}
Thesis submitted
to the Davis College of Agriculture, Natural Resources and Design

at West Virginia University
\end{abstract}

in partial fulfillment of the requirements for the degree of

Master

of Landscape Architecture

Peter Butler, MLA. Chair

Angela Campbell, MLA.

Hodjat Ghadimi, Ph.D.

Landscape Architecture/Environmental Design Program

Morgantown, West Virginia

2013

Keywords: Surface Mining, Renewable Energy, Eco-Industrial Park, Conceptual Design, Stormwater Management, Planting Design

Copyright 2013 Jing Chu 


\begin{abstract}
Mountain Top Eco-Industrial Park

An Eco-industrial, Renewable Energy Approach for Industrial Park Development
\end{abstract}

\author{
Jing Chu
}

This project applies the concepts of industrial ecology and recreational gateway development to the redesign of an existing industrial park - Mountain Top Industrial Park in Grant County, West Virginia. The location of the existing industrial park, in close proximity to the CSX railroad and the future Corridor $\mathrm{H}$ expressway corridor, lends itself to eco-industrial development and may function as a touristic gateway to the region. The site is at the center of an 'energy' complex: Mount Storm Power Plant and former surface mines. Extractive industries and energy production will be a theme within the design project. An Eco-Industrial Park model will be applied in looking to a sustainable energy future for the site and the region.

The result of this investigation is a new, common sense, approach to industrial park development that combines economic growth and environmental protection. Eco-Industrial parks make use of the raw material of industry and look to developing local industries to create a web of reuse and recycling of the waste products generated by existing facilities. Examples of potential materials for reuse include biomass from timber operations, waste from coal power plants, and agricultural wastes from regional cultivated fields. 


\section{ACKNOWLEDGEMENTS}

Without the support of my advisor, colleagues, friends and family, the completion of this thesis would have never been possible. First of all, I would like to express my gratitude to my supervisor Professor Peter Butler. He served as more of a mentor than a professor throughout my graduate study. I want to thank to him for his unending patience, guidance and assistance during my time at West Virginia University.

I would like to thank my committee members Dr. Hodjat Ghadimi, Professor Angela Campbell. Thanks for their support and invaluable suggestions during this research.

This work was performed under a project finished by the Northern West Virginia Brownfields Assistance Center. Thanks for their support and sponsorship. I would like to thank Patrick Kirby, Derek Springston and Professor Christine Risch from Marshall University for their help, support and guidance during the database inventory and analysis.

I would like to thank Professors Charles Yuill, Kathryn Wittner, Steven McBride, Ashley Kyber, and Carrie Moore; and Ms. Dianna Spring who gave me lots of help and support when I was at West Virginia University.

I would like to give my best thanks and wishes to my friends, Claire Jeran, Ayaka H. Matthews and Maria J. Lloreda and other graduate students in the Department of Landscape Architecture at West Virginia University.

More importantly, I want to thank my lovely husband, Peng Zhang, for encouragement, patience and support. Also, thanks for my son, Andy Zhang, for bringing happiness to my work and study. 


\section{Table of Contents}

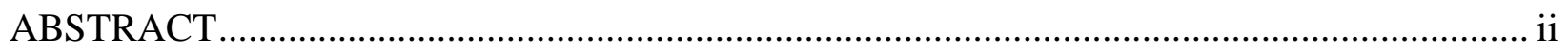

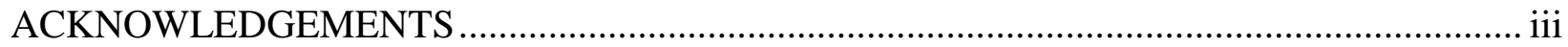

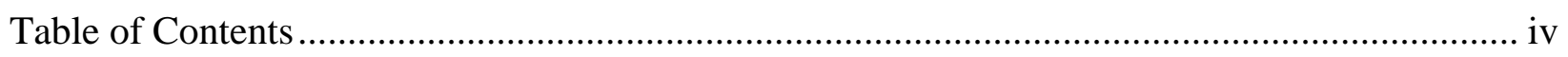

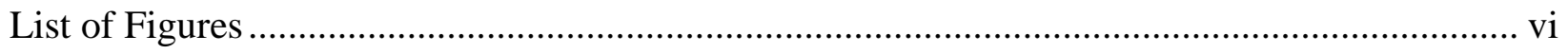

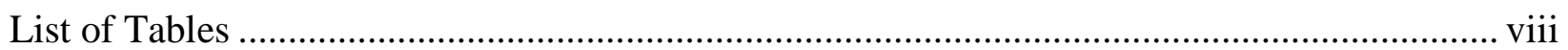

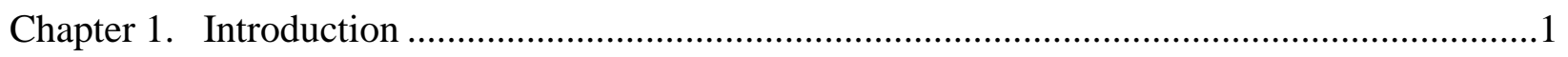

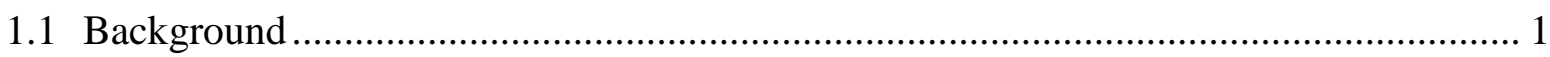

1.1.1 Surface Mining......................................................................................... 1

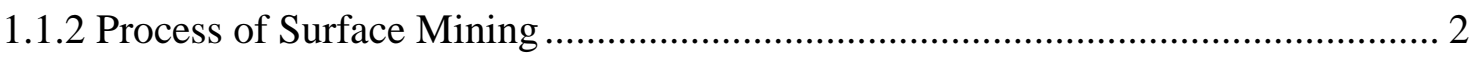

1.1.3 Sustainable Energy Parks............................................................................... 3

1.1.4 Project Site - Mountain Top Industrial Park ........................................................ 4

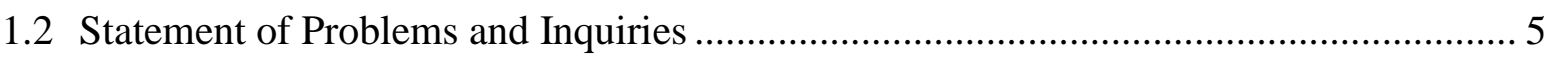

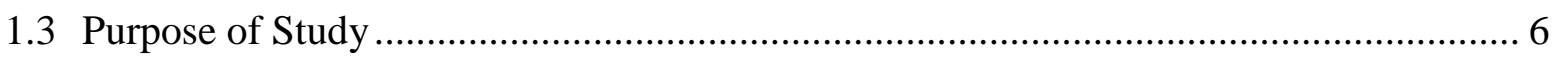

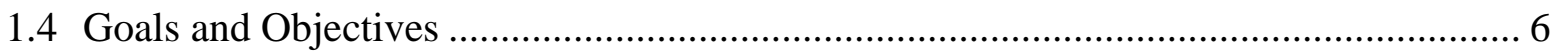

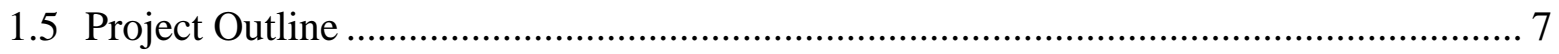

1.5.1 Phase 1: Inventory \& Analysis ...................................................................... 7

1.5.2 Phase 2: Conceptual Design.......................................................................... 7

1.5.3 Phase 3: Stormwater Management...................................................................... 7

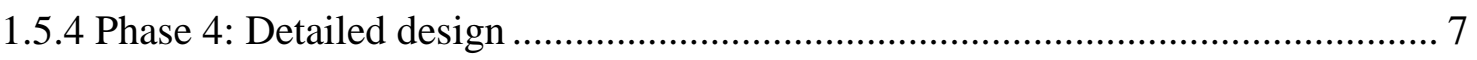

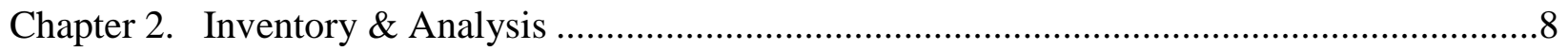

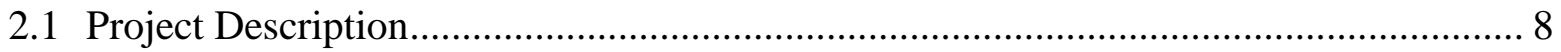

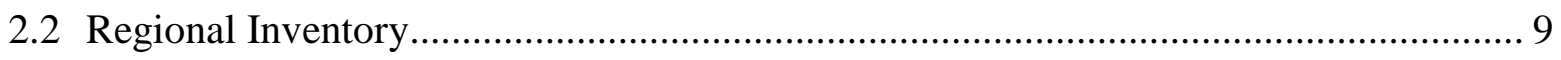

2.2.1 Adjacent Communities - Economic Drivers ......................................................... 9

2.2.2 Recreational Destinations .......................................................................... 10

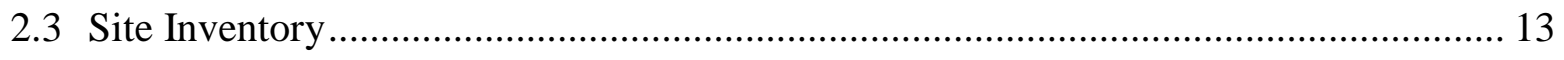

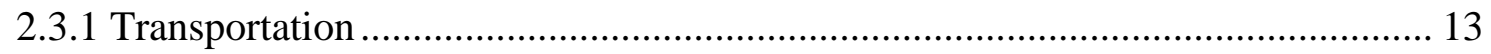

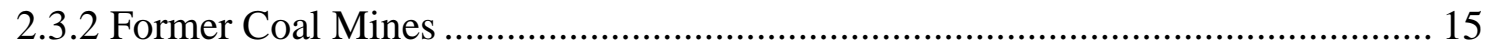

2.3.3 Mount Storm Power Plant \& Trans-Allegheny Interstate Line (TrAIL) ............. 15

2.3.4 Environmental Assessment ............................................................................ 16 
2.3.5 Summary from Environmental Inventory \& Analysis .................................... 18

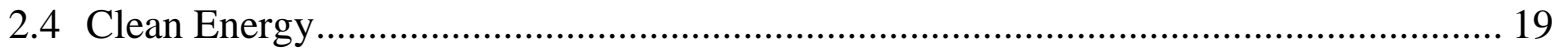

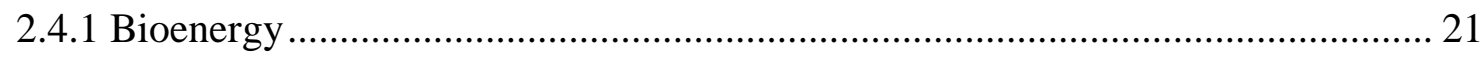

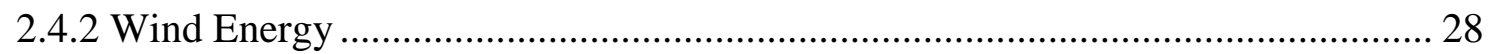

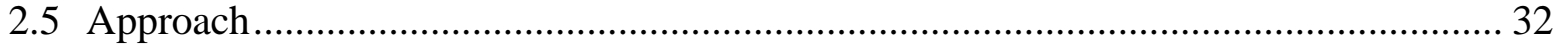

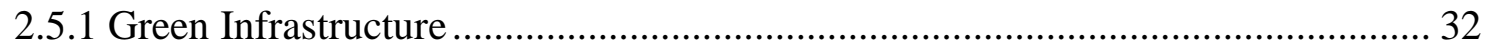

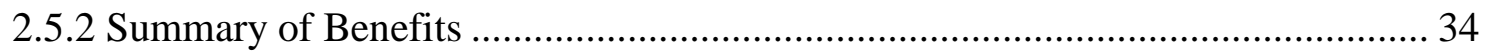

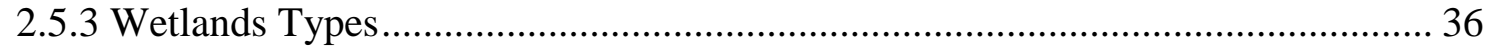

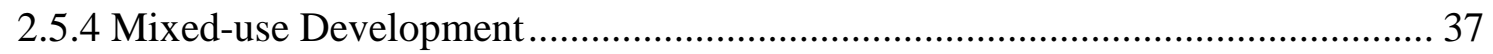

2.6 Summary from Inventory \& Analysis............................................................. 38

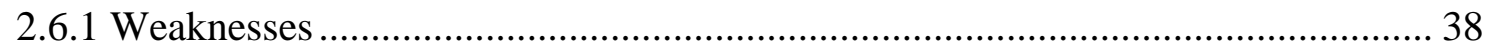

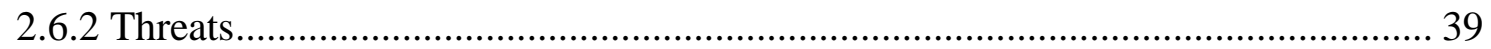

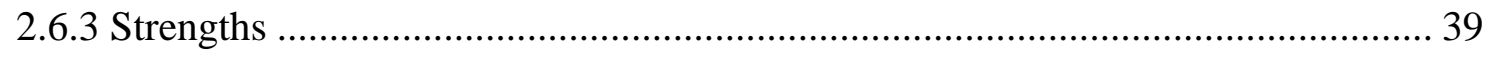

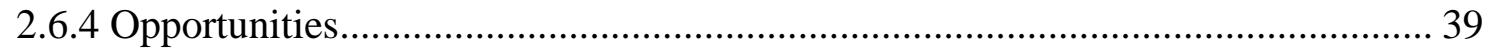

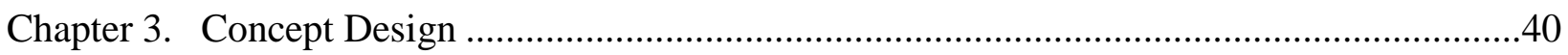

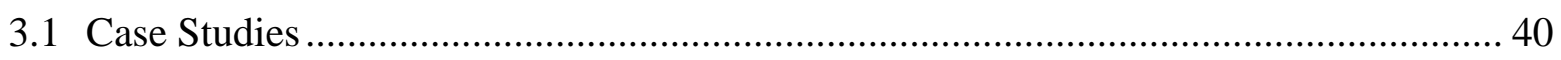

3.1.1 Qunli Stormwater Park - Haerbin City, China ............................................. 40

3.1.2 TaigaNova Eco-Industrial Park- Fort McMurray, Canada................................ 41

3.1.3 Renewable Energy Education Park- Pushpa Gujral Science City, India ............ 43

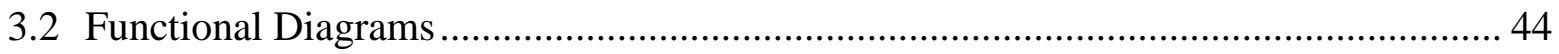

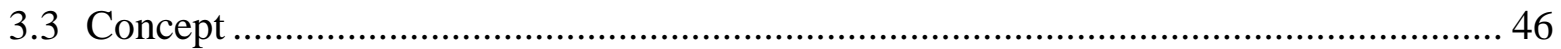

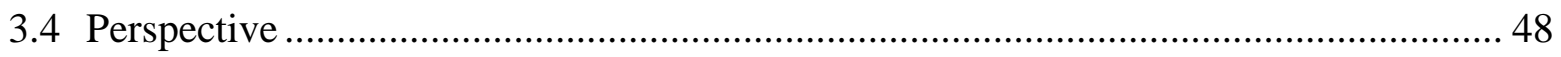

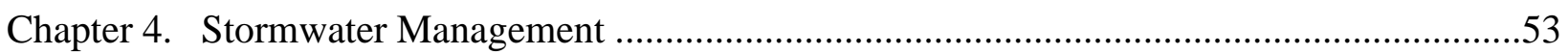

4.1 Chesapeake Stormwater Design Criteria ............................................................. 53

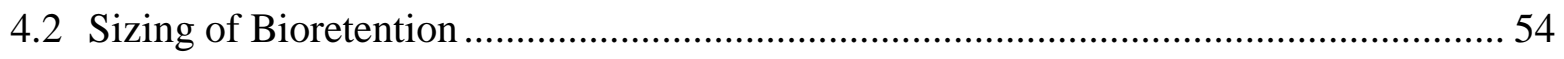

4.2.1 Bioretention Surface Area in Mountain Top Industrial Park............................. 56

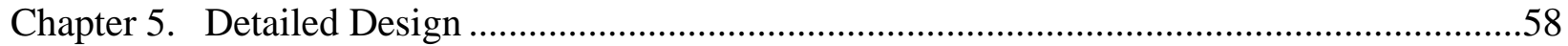

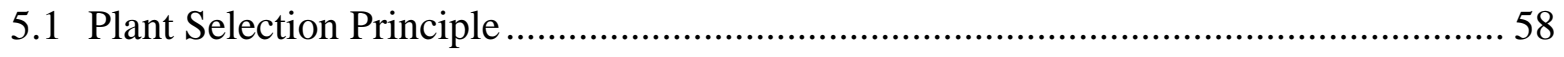

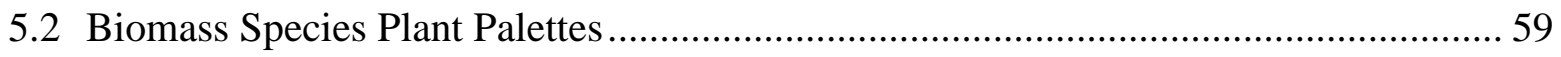

5.3 Bioretention \& Wetland Plant Palettes ................................................................. 59

References 65 


\section{List of Figures}

Figure 1. Location of Upper Potomac Coalfield.............................................................. 1

Figure 2. West Virginal Coalfields ....................................................................................... 2

Figure 3. Process of Surface Mining .................................................................................... 3

Figure 4. Coalfield in Mountain Top Industrial Park ........................................................ 4

Figure 5. Western Maryland Railroad in Upper Potomac Coalfield ........................................ 5

Figure 6. Location of Mountain Top Industrial Park .............................................................. 8

Figure 7. Location of Adjacent Communities............................................................... 9

Figure 8. Geography \& Demographics of Adjacent Communities......................................... 10

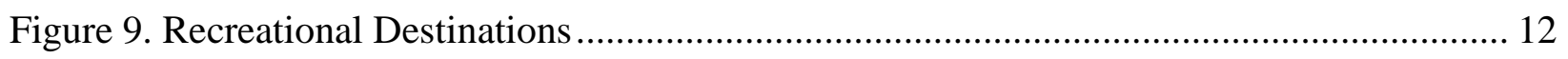

Figure 10. Site Inventory of Mountain Top Industrial Park ................................................. 12

Figure 11. Entire Route of Proposed Corridor H ............................................................. 14

Figure 12. Construction Status of Proposed Corridor H..................................................... 14

Figure 13. Clearance Zone for TrAIL Transmission Line .................................................. 15

Figure 14. Slope \& Hillshade of Mountain Top Industrial Park............................................... 16

Figure 15. Topography \& Soil Types of Mountain Top Industrial Park ................................. 17

Figure 16. Soil Types Descriptions of Mountain Top Industrial Park Soils............................. 17

Figure 17. Summary from Environmental Inventory \& Analysis .......................................... 19

Figure 18. Price Estimates from Traditional Energy \& Clean Energy ..................................... 20

Figure 19. Energy Moves from Energy Generators to Your Home.......................................... 21

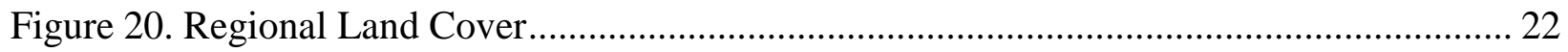

Figure 21. Proximity to Railroad \& Mount Storm Power Station .......................................... 23

Figure 22. Unemployment Rate for Maryland \& West Virginia ........................................... 26

Figure 23. Wind Resources at Mountain Top Industrial Park ............................................... 29

Figure 24. Wind Turbines Layout in Mountain Top Industrial Park ....................................... 29

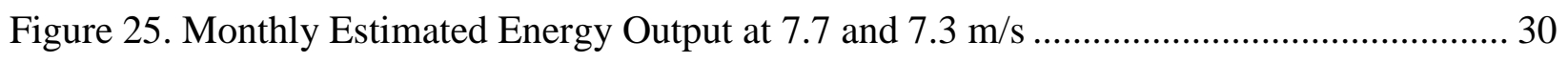

Figure 26. Solar Resources at Mountain Top Industrial Park ............................................... 31

Figure 27. Typical Extensive Green Roof Cross - Section ................................................ 33

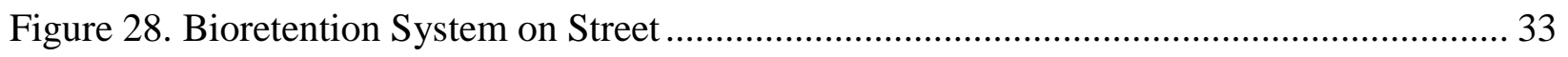


Figure 29. Wetland Types and Their Associated Wetland Zones ............................................... 36

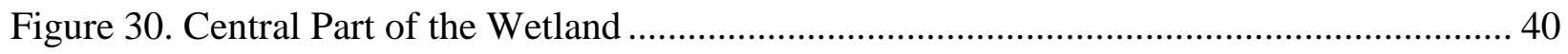

Figure 31. Aggressive - Growing Trees \& Network of Paths .................................................... 40

Figure 32. Relation to Fort McMurray town center \& Hwy 63N ……………………................. 42

Figure 33. Energy efficient buildings \& infrastructure ................................................................. 42

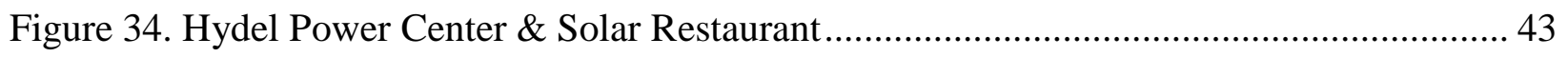

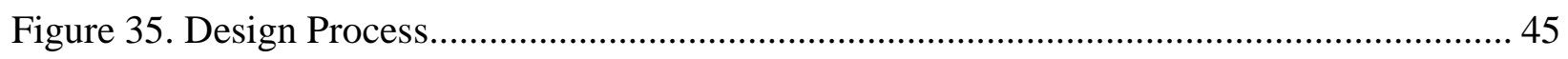

Figure 36. Mountain Top Industrial Park Master Plan ............................................................... 46

Figure 37. Local Landscape Patterns .................................................................................... 47

Figure 38. Mountain Top Industrial Park Master Plan - Development Area ............................... 47

Figure 39. Gas Station Serves for Industrial \& Commercial Areas................................................ 48

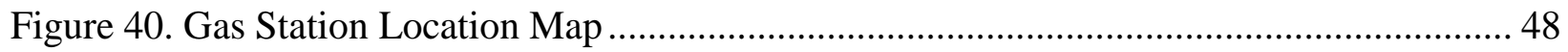

Figure 41. Local Retail \& Lodging ...................................................................................... 49

Figure 42. Local Retail \& Lodging Location Map ………...................................................... 49

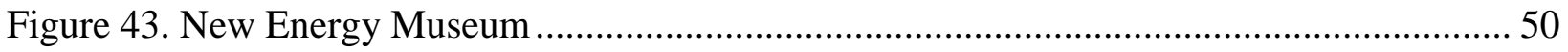

Figure 44. New Energy Museum Location Map …………........................................................ 50

Figure 45. Wetland \& Natural Playground ................................................................................. 51

Figure 46. Wetland \& Natural Playground Location Map .............................................................. 51

Figure 47. Bioretention \& Surface Mine Museum ................................................................... 52

Figure 48. Bioretention \& Surface Mine Museum Location Map .................................................. 52

Figure 49. Typical Bioretention Section with Void Ratios for Volume Computations ................ 55

Figure 50. Stormwater Strategies \& Locations in Mountain Top Industrial Park ......................... 57

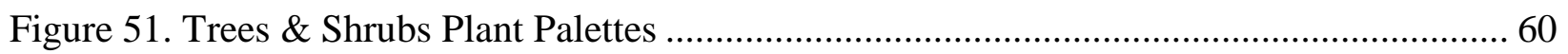

Figure 52. Biomass Species Plant Palettes ....................................................................................... 61

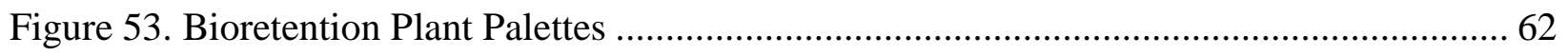

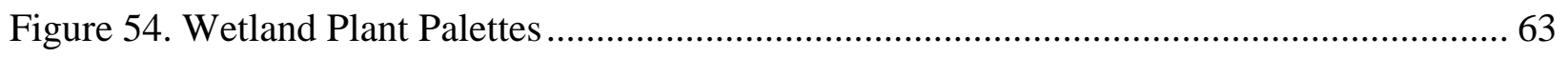

Figure 55. Bioretention Section \& Wetland Section ............................................................. 64 


\section{List of Tables}

Table 1. Demographics and Economic Profile for Grant, Tucker County, Preston County, Mineral County, Garrett County, Allegany County, WV, MD and U.S. ("STATS America,")... 25

Table 2. Bioenergy Economic Benefits from Grant, Tucker, Preston, Mineral, Garrett and Allegany Counties (Wang, Grushecky, \& McNeel, 2007) ………………................................. 27

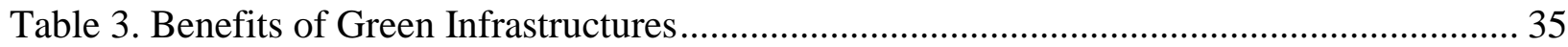

Table 4. Summary of Stormwater Functions Provided by Bioretention Basins ............................ 53

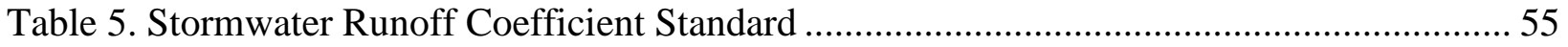

Table 6. Minimum Sizing of Bioretention \& Design Bioretention Surface Area ......................... 56 


\section{Chapter 1. Introduction}

\subsection{Background}

\subsubsection{Surface Mining}

Surface mining began in the mid-sixteenth century, and is practiced throughout the world. It gained popularity throughout the $20^{\text {th }}$ century, and is now the predominant form of mining in coal beds such as those in Appalachia and America's Midwest. Sites of surface mining in Appalachia range from Ohio to Virginia, and south to Georgia. It occurs most commonly in West Virginia and Eastern Kentucky, the top two coal-producing states in Appalachia ("Surface mining," 2013).

In the late $20^{\text {th }}$ Century, an estimated 100,000 surface coal mines occupied millions of acres of land throughout Appalachia, which were mined prior to 1977, subsequently abandoned or reclaimed and closed with a minimal degree of restoration.

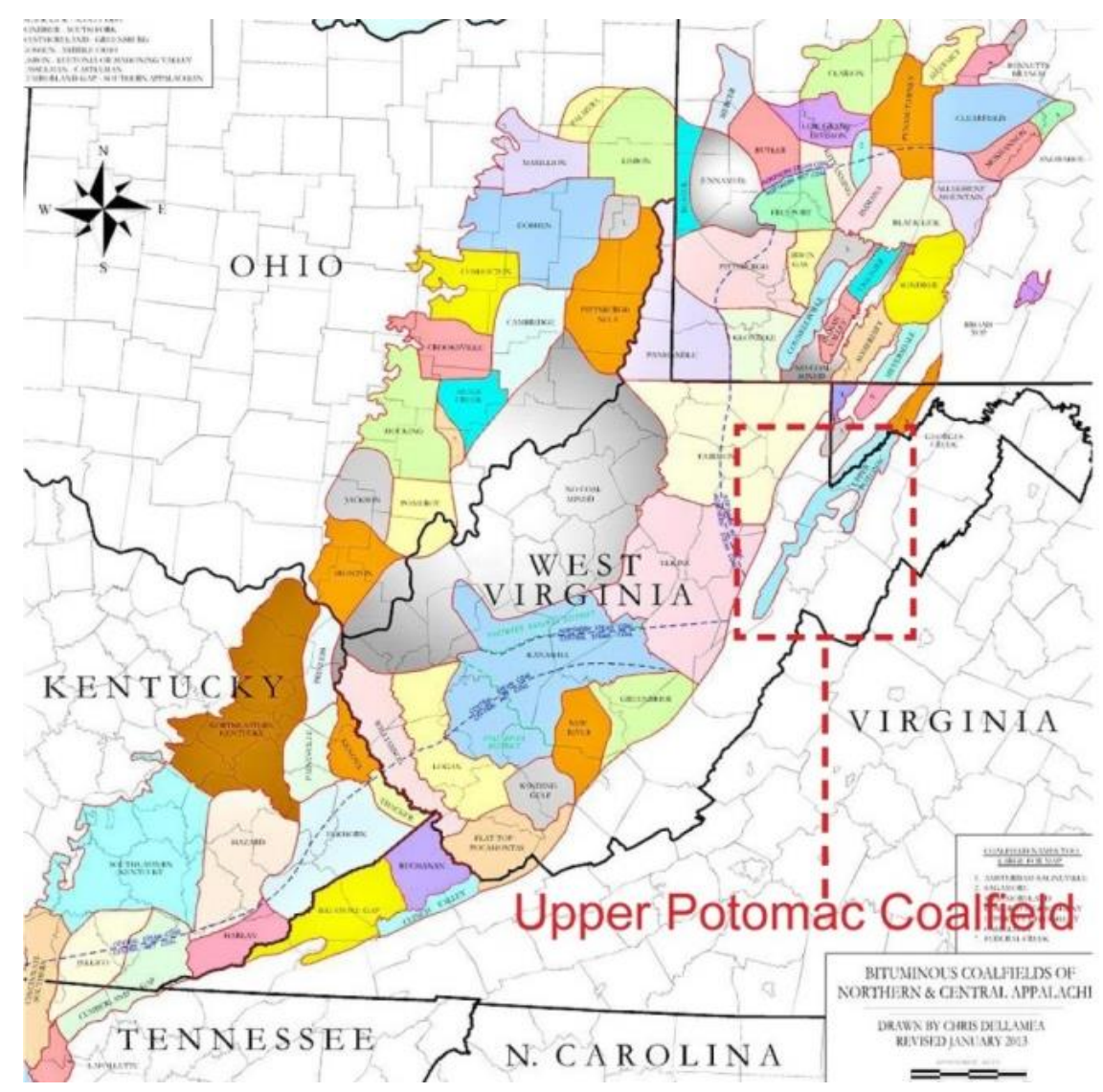

Figure 1. Location of Upper Potomac Coalfield 


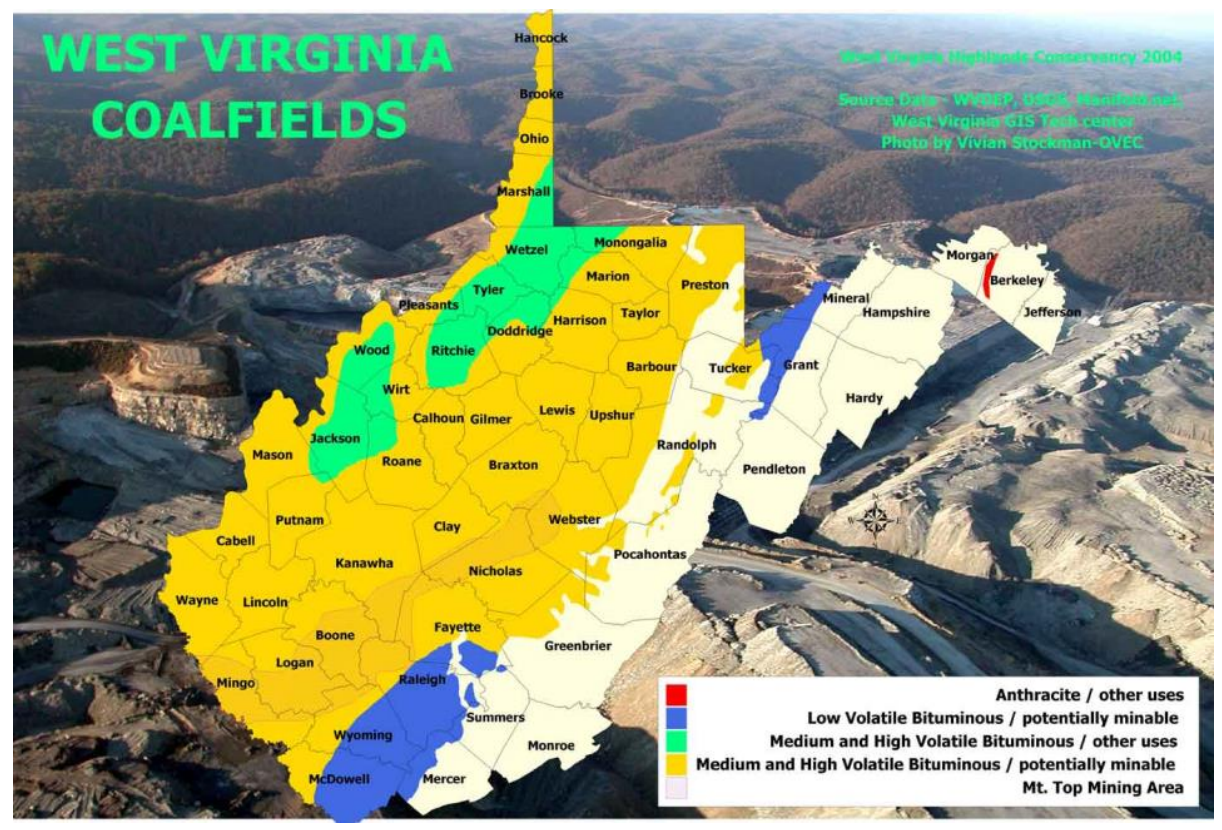

Figure 2. West Virginal Coalfields

The project site - Mountain Top Industrial Park is located within the Upper Potomac Coalfield, which is a distinct coalfield from Northern West Virginia Coalfield (Figure 1). The Upper Potomac Coalfield is a low-volatile coalfield centered on the Upper Freeport seam of coal (Figure 2). Some surface coal mines have been abandoned after years of mining in the Upper Potomac. Mountain Top Industrial Park is adjacent to many former surface coal mines.

\subsubsection{Process of Surface Mining}

The process of surface coal mining creates a disturbance in the landscape (Figure 3). Once the area is deforested and cleared, Layers of rock and dirt above the coal (called overburden) are removed to expose coal seams beneath. The overburden is then moved by various mechanical means to areas of the ridge previously mined. If the ridge topography is too steep to adequately handle the amount of spoil produced then additional storage is used in a nearby valley or hollow, which is known as valley fill. The coal is removed by excavators and then transported to a processing plant. Once coal removal is completed, the mining operators back stack overburden from the next area to be mined in to the now empty pit. Then the topsoil is layered over the overburden layer and the area is revegetated ("Mountaintop removal mining," 2013). 


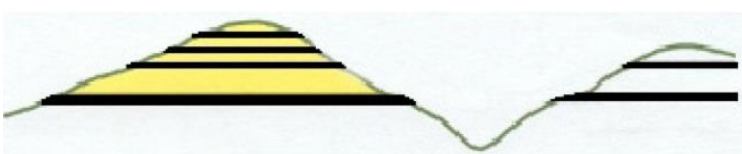

Step 1. Layers of rock and dirt above the coal (called overburden) are removed

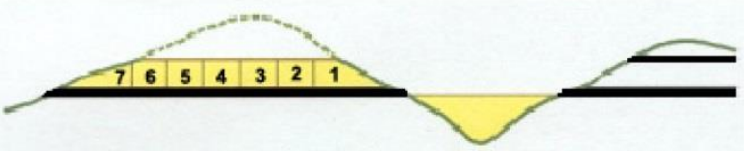

Step 2. The upper seams of coal are removed with spoils placed in an adjacent valley

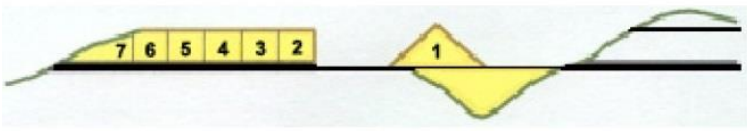

Step 3. Draglines excavate lower layers of coal with spoils placed in spoil piles

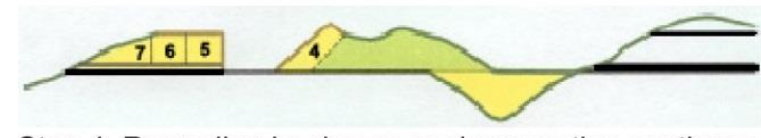

Step 4. Regrading begins as coal excavation continues

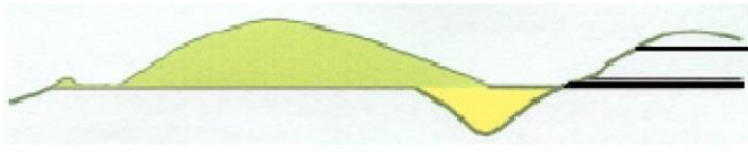

Step 5. Once coal removal is complete, final regrading takes place and the area is revegetated

Figure 3. Process of Surface Mining

The process of surface mining creates complex economic, social and environmental issues on adjacent sites. Cleanup of adjacent lands for redevelopment provides an opportunity to transform these sites into land that has beneficial and productive uses. They have a variety of potential reuses, including recreation, wildlife habitat, rangeland, historic and scenic preservation, and, depending on location and soil composition, conventional residential, commercial, and industrial construction. Complex economic, social, and environmental issues face communities planning to redevelop these sites.

\subsubsection{Sustainable Energy Parks}

The Northern West Virginia Brownfields Assistance Center (NBAC) at West Virginia University (WVU) and the Center for Business and Economic Research (SBAC) at Marshall University promotes economic development and environmental and public health protection through innovative redevelopment of brownfield sites in West Virginia. Mine-scarred lands are considered brownfields by the Environmental Protection Agency (EPA).

An inventory of former surface mined land throughout West Virginia was created and blended with assessment data by the Natural Resources Analysis Center (NRAC) at WVU, NBAC and SBAC to produce a portfolio of 612 surface coal mine sites that are positioned as viable production areas for biofuels and other types of alternative energy such as wind and solar.

Mountain Top Industrial Park in Grant County meets the candidate selection criteria including slope suitability for switchgrass, potential acreage for biofuel stockpiling, existing infrastructure (roads, railroads, and utilities), proximity to potential markets, and accessibility for 
assessments and potential for wind, solar and geothermal energy that create an opportunity for the production of a comprehensive sustainable energy park development plan.

\subsubsection{Project Site - Mountain Top Industrial Park}

Mountain Top Industrial Park is located within Upper Potomac Coalfield, which covers an area of 182 acres (Figure 4). The coalfield, which was named after the North Branch of the Potomac River that drains the region, occurs in both Maryland and West Virginia. Mining began in the 1880's, and was in the Lower Kittanning and Upper Freeport coal seams, which are considered low volatile coals in this area.

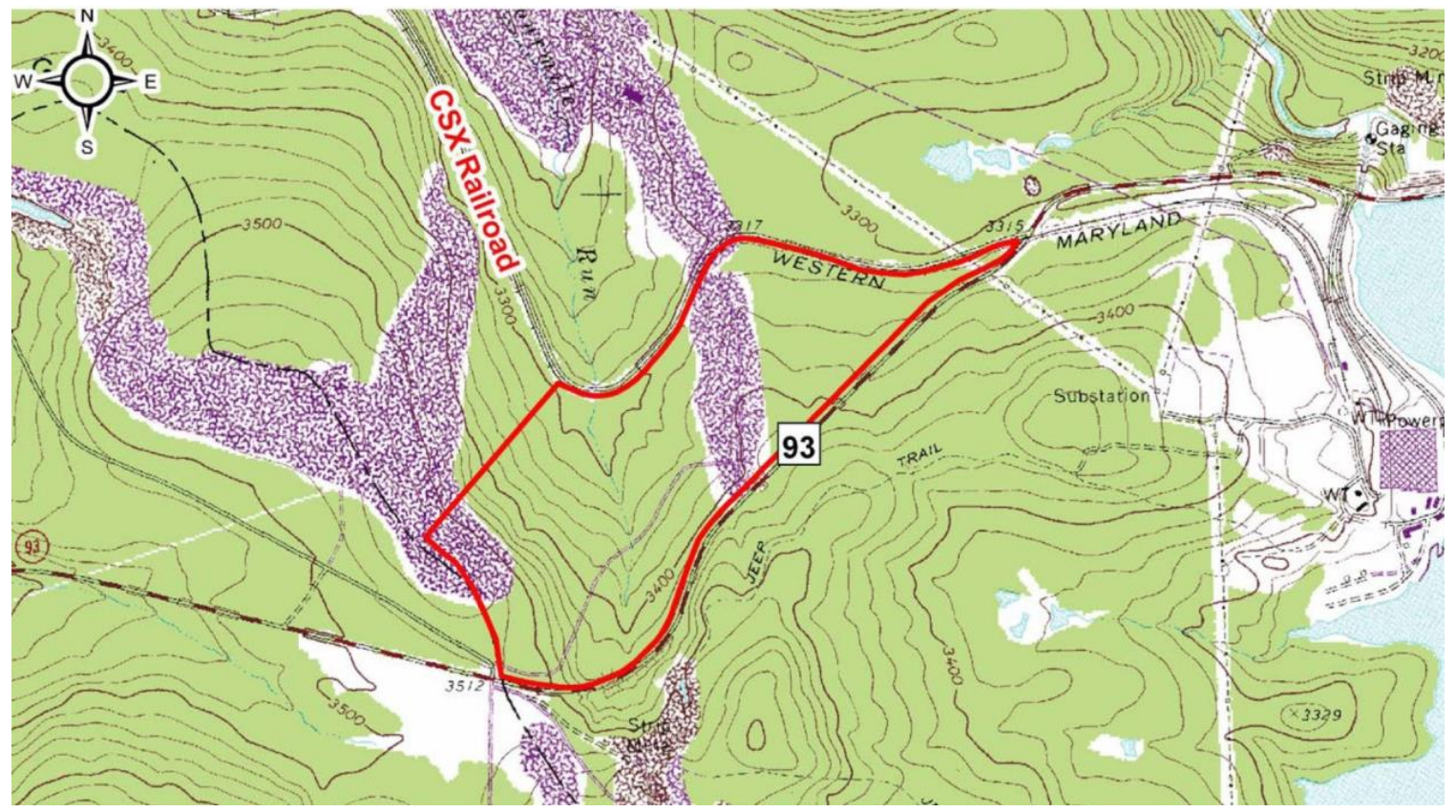

Figure 4. Coalfield in Mountain Top Industrial Park

Most of the Upper Potomac Coalfield was served by the Western Maryland Railroad, which intersected with the B\&O near Keyser, WV ("Upper Potomac Coalfield,"). Some of the coal, however, was shipped to market on the C\&O Canal. Early developers considered the coalfield advantageous because it was closer to the Virginia Tidewater shipping ports than most other Appalachian coalfields (Figure 5). 


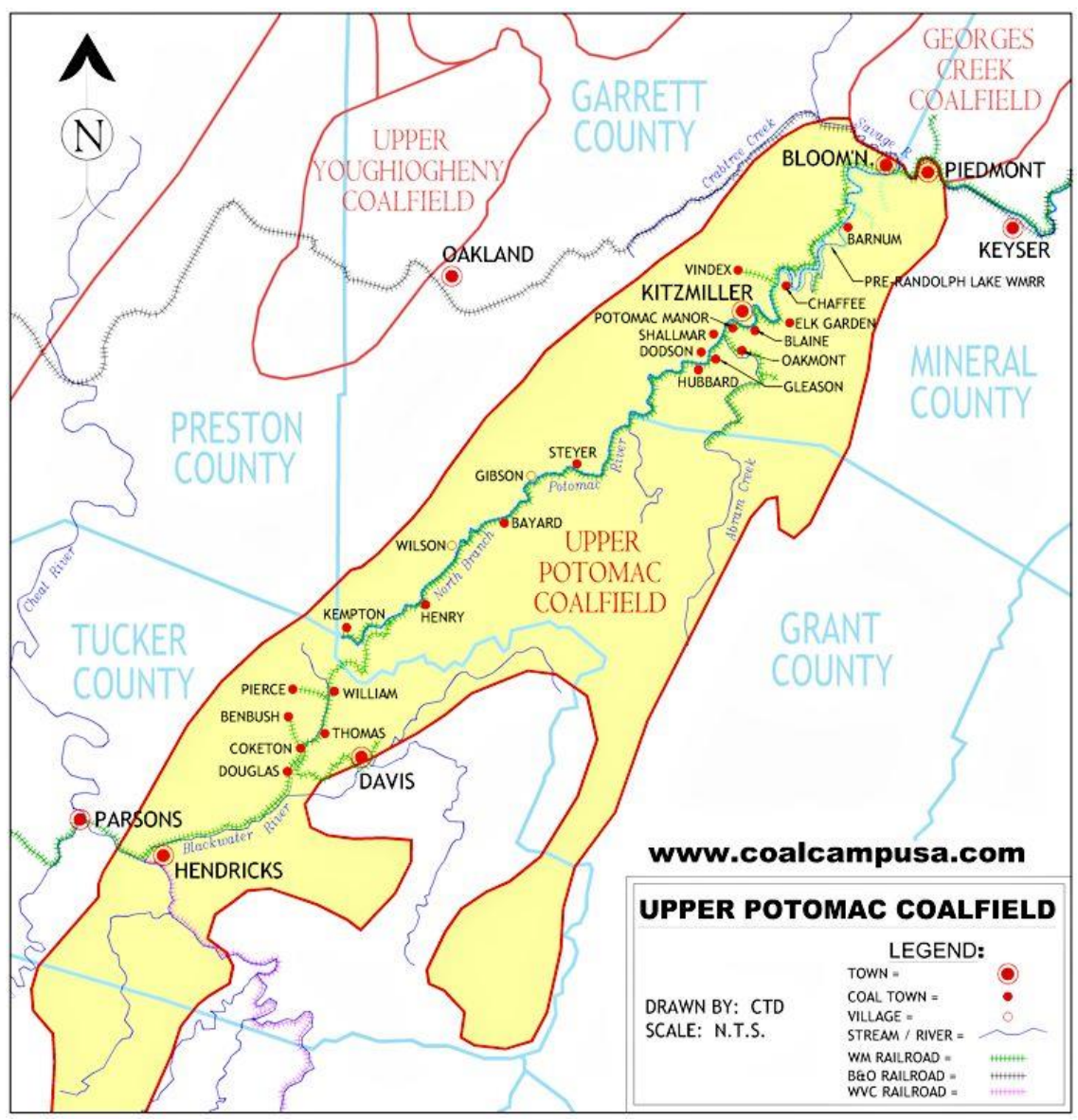

Figure 5. Western Maryland Railroad in Upper Potomac Coalfield

\subsection{Statement of Problems and Inquiries}

Surface mining creates economic and environmental challenges in the clean-up and reuse of adjacent sites. Adjacent sites often have sparse vegetation, polluted water and poor soil, which can depress land value and are difficult to redevelop. In an effort to reduce water pollution on the site, sustainable practices, including green infrastructure design, are proposed to reduce stormwater runoff and mimic ecological processes using soil and plant mediums to cleanse, cool and slow water instead of traditional stormwater conventions.

In this study, the renewable energy and mixed-use development have to be considered in conjunction with location, terrain, transportation, local work force, and other factors. Integrating mixed-use design principles and the application of renewable energy into community development have the potential to change the economic and environmental landscape of small communities in this distressed region, as this project will demonstrate. 


\subsection{Purpose of Study}

The objective of this study is to explore the components of sustainable energy including biomass, wind and solar, mixed use development, and apply those principles to match new development to current trends in education and nature-based tourism.

The impact of bringing an alternative energy production and processing industry back to coalfield communities may be significant. In its most recent comprehensive plan, Grant County has identified a commitment to promote and increase clean energy output, as well as a preference for economic development in energy and high-tech industries.

The redevelopment plan for Mountain Top Industrial Park would take advantage of infrastructure associated with previous industrial transportation and the local workforce's knowledge of energy. The project is an opportunity to create new opportunities for the region that has lost its economic drivers- surface mines and a coal preparation plant.

The project will provide a framework for developing Sustainable Energy Parks (SEPs) in Appalachia, which will seek to attract financing for productive economic development projects within the host communities. This project may provide a new direction for other communities facing similar challenges by taking advantage of eco-industrial opportunities and local natural resources.

\subsection{Goals and Objectives}

Design a new eco-industrial park in western Grant County, WV.

- Create a sustainable energy park by applying sustainable energy technologies in biofuels, wind, and solar.

- Identify existing environmental concerns within the industrial park related to adjacent former surface coal mines.

- Make use of the raw material of industry through reuse and recycling of the waste products generated by existing facilities. 
Design a sustainable mixed - use development within the park that can serve as an educational resource to local schools, universities and business groups.

- Design a commercial district focused upon shared amenities, such as walkable shopping areas, recreation area and create a place to instill pride in local residents.

- Design green infrastructure to slow runoff, infiltrate water with methods such as bioswales, constructed wetlands and green roofs.

- Minimize maintenance needs by efficient use of plant and construction materials.

\subsection{Project Outline}

The design process for this project included the collection of base data and the analysis of the data's influence on design, which will assist in achieving the goals for which it was conceived. The process consisted of:

\subsubsection{Phase 1: Inventory \& Analysis}

Understand the proposed site and the relationships that exist between the components of the adjacent communities and geographical area though inventory \& analysis of the environmental, social, and economic contexts.

\subsubsection{Phase 2: Conceptual Design}

Generate design solutions that are informed by the inventory and analysis of existing conditions, future needs, constraints of the site and adjacent human activities.

\subsubsection{Phase 3: Stormwater Management}

Analyze the stormwater impacts of the proposed land use and make stormwater more integral with conceptual design.

\subsubsection{Phase 4: Detailed design}

Propose planting design - suggestions of materials, textures, colors, planting, etc. to reimagine the site as defining a progressive character for the region. 


\section{Chapter 2. Inventory \& Analysis}

\subsection{Project Description}

The Mountain Top Industrial Park in Grant County covers an area of 182 acres, which has public service provided by CSX railroad and State Routes 42 and 93 currently (Figure 6). In the future the site will be connected through the new Corridor H expressway to Washington D.C and points in between. The site is owned by Grant County Development Authority.

Grant County is 478 square miles rich in natural resources, which is located in the Potomac Highlands of West Virginia, ranging from the Allegheny Front and Dolly Sods in the north to the broad beautiful valley of the South Branch of the Potomac River. Grant County was created in 1866 from Hardy County and named in honor of Ulysses S. Grant (1822-1885) ("Grant County, West Virginia," 2013).

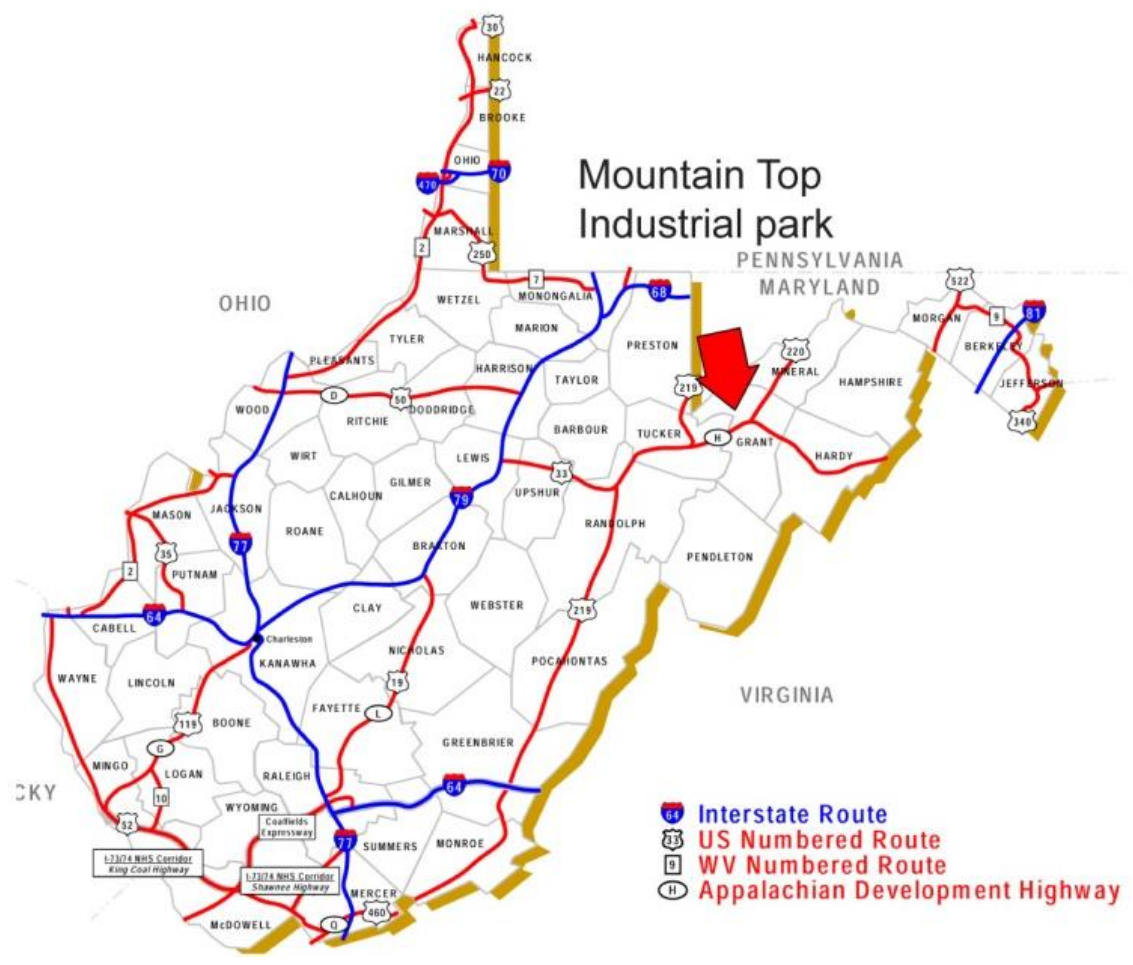

Figure 6. Location of Mountain Top Industrial Park

The community associated with this project is Mount Storm, West Virginia, which lies on U.S. Route 50 at its junction with WV Route 42. It is an unincorporated community in Grant 
County, WV of fewer than 1,000 people. Mount Storm is the site of Mount Storm Power Station, Mount Storm Lake, Union School Complex and the Ned Power Wind Farm ("Mount Storm, WV," 2012).

\subsection{Regional Inventory}

\subsubsection{Adjacent Communities - Economic Drivers}

The communities in proximity to Mountain Top Industrial Park: Mount Storm, Bayard, Davis and Thomas (Figure 7), are small communities of fewer than 1000 people (Figure 8). All of them have a long history of coal and timber production beginning in approximately 1880 .

The region has been defined by a balance of rural wooded mountain tops and energy industries for decades. Right now they have lost their economic drivers of years past such as surface mines and coal preparation plants as the coal resource has diminished. Davis and Thomas are moving towards an economy based on the tourism industry.

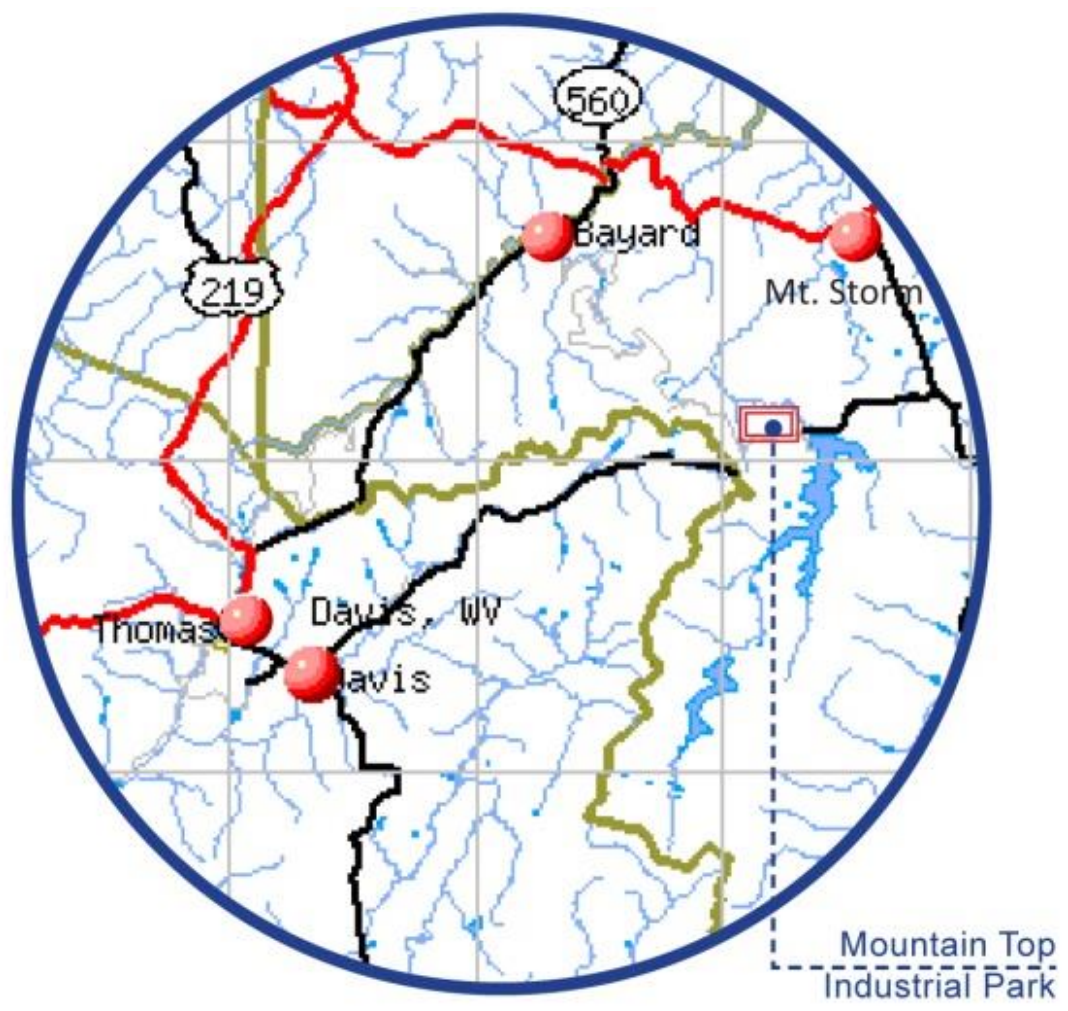

Figure 7. Location of Adjacent Communities 


\begin{tabular}{|c|c|c|c|c|}
\hline & $\begin{array}{l}\text { Mount Storm } \\
\text { Grant County }\end{array}$ & $\begin{array}{c}\text { Bayard } \\
\text { Grant County }\end{array}$ & $\begin{array}{c}\text { Davis } \\
\text { Tucker County }\end{array}$ & $\begin{array}{c}\text { Thomas } \\
\text { Tucker County }\end{array}$ \\
\hline Area & $\begin{array}{c}\text { Unincorporated } \\
\text { Community }\end{array}$ & Town & Town & City \\
\hline Total Area & - & $0.31 \mathrm{sq} \mathrm{mi}$ & $1.83 \mathrm{sq} \mathrm{mi}$ & $4.51 \mathrm{sq} \mathrm{mi}$ \\
\hline Land Area & _ & $0.31 \mathrm{sq} \mathrm{mi}$ & $1.83 \mathrm{sq} \mathrm{mi}$ & $4.46 \mathrm{sq} \mathrm{mi}$ \\
\hline Water Area & _ & $0 \mathrm{sq} \mathrm{mi}$ & $0 \mathrm{sq} \mathrm{mi}$ & $0.05 \mathrm{sq} \mathrm{mi}$ \\
\hline Elevation & & $2,343 \mathrm{ft}$ & $3,100 \mathrm{ft}$ & $3,035 \mathrm{ft}$ \\
\hline \multicolumn{5}{|l|}{ Population } \\
\hline Population (2010) & 708 & 290 & 660 & 586 \\
\hline Population (2011) & - & 288 & 648 & 577 \\
\hline Density & - & $935.5 / \mathrm{sq} \mathrm{mi}$ & $360.7 / \mathrm{sq} \mathrm{mi}$ & $131.4 / \mathrm{sq} \mathrm{mi}$ \\
\hline Median Age & 46.9 & 44.5 & 46.1 & 56.6 \\
\hline
\end{tabular}

Figure 8. Geography \& Demographics of Adjacent Communities

\subsubsection{Recreational Destinations}

Mountain Top Industrial Park is surrounded by many recreational destinations, Monongahela National Forest including Blackwater Falls State Park and Blackwater Wildlife Management Area to the west and Canaan Valley National Wildlife Refuge to the south. Mount Storm Lake is found towards the east side of the industrial park. Beaver Creek, to the west, connects the property with Davis in the western portion of the industrial park (Figure 9).

\section{$>$ Monongahela National Forest (MNF)}

Monongahela National Forest was established in 1920 and is located in the north central highlands of West Virginia. Variations in terrain have created one of the most ecologically diverse National Forests in the country. It produces timber, water, grazing, minerals and recreational opportunities for the region and nation ("Monongahela National Forest," 2013).

\section{Blackwater Wildlife Management Area}

The Blackwater Wildlife Management Area is close to 58,978 acres, and consists primarily of mountainous terrain covered in oak-hickory, northern hardwood, spruce, fir, and 
white-pine forests with 2,743 acres of scattered openings. Hunting opportunities abound for bear, turkey, and deer. The Blackwater River, Horseshoe Run, Clover Run, and Slip Hill Run provide excellent trout fishing ("Blackwater Wildlife Management Area," 2004).

\section{Blackwater Falls State Park}

Blackwater Falls State Park is named for the falls of the Blackwater River, which are one of the most photographed sites in West Virginia. The Blackwater lodge, cabins and restaurant are open year-round and welcome visitors to enjoy winter sled riding, spring greening, cool summer evenings, and autumn foliage ("The official Site of Blackwater Falls State Park," 2009).

\section{$>$ Canaan Valley National Wildlife Refuge}

Canaan Valley National Wildlife Refuge preserves the unique wetlands and uplands of this high elevation area. One may enjoy the Refuge by participating in wildlife-dependent recreation, including wildlife observation and photography, hunting, fishing, environmental education, and nature programs ("Canaan Valley National Wildlife Refuge," 2013).

\section{Mount Storm Lake}

Mount Storm Lake, also known as New Stony River Reservoir, is a 1,200 acre reservoir created in 1965 on the Stony River in Grant County, WV. Mount Storm Lake was not only built to serve the Mount Storm Power Station, but also serves as a public recreation area. The warm water circulation through the power station makes the lake an attractive year around destination for scuba divers, boaters and fishermen ("Mount Storm Lake," 2013).

\section{$>$ Beaver Creek}

Beaver Creek parallels Route 93 coming across the mountain into Davis, WV. Beaver Creek begins very small and is often barely wide enough to turn a boat around. The stream calms downstream next to Route 93 ("Beaver Creek - Headwaters along Rte. 93 to Blackwater River," 1999). 

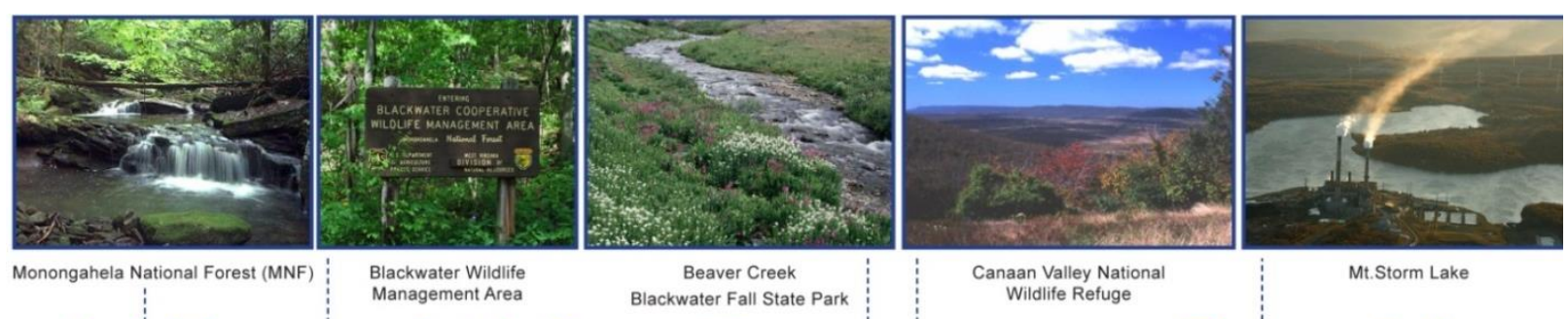

Canaan Valley National

Mt.Storm Lake

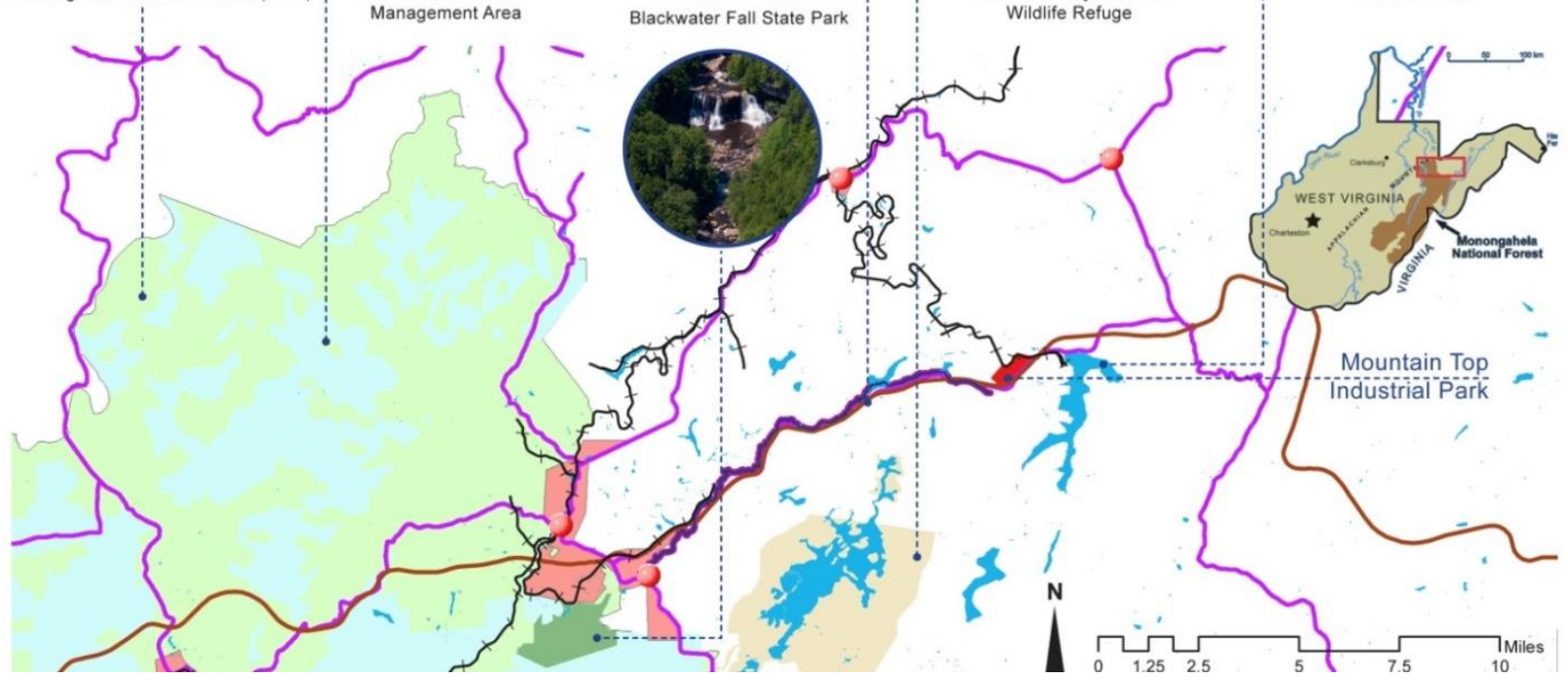

Figure 9. Recreational Destinations

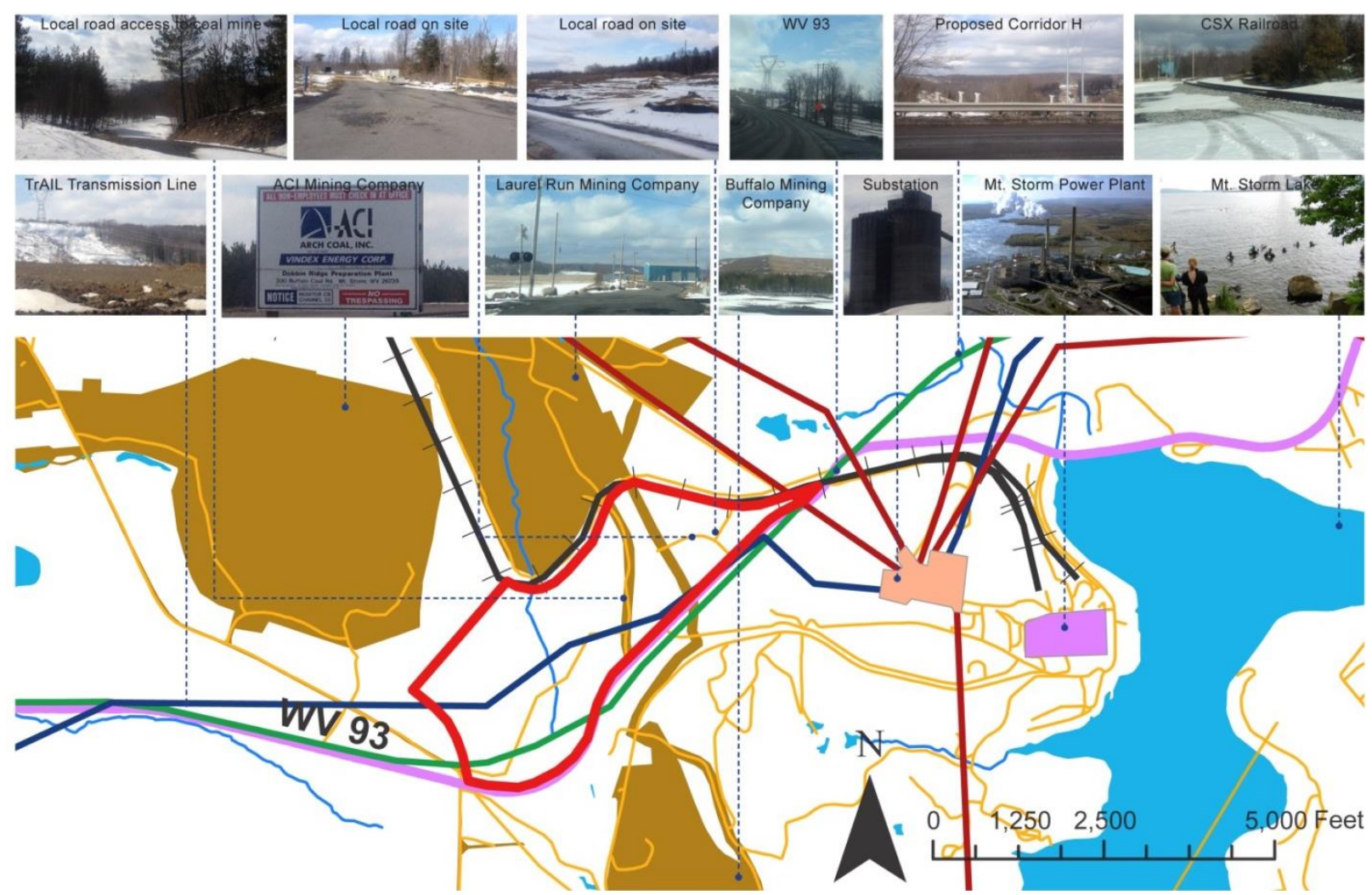

Figure 10. Site Inventory of Mountain Top Industrial Park 


\subsection{Site Inventory}

Mountain Top Industrial Park is at the center of an 'energy' complex: Mount Storm Power Plant, NedPower Wind Farm and three former surface mines surrounded the site. Mount Storm Electricity Substation and new TrAIL transmission line are used to transfer power from the transmission system to the distribution system of a vast area (Figure 10). The significant transportation resources: the CSX Railroad on the north, Route 93 and proposed the Corridor $\mathrm{H}$ on the south will provide visitors with easy access to the site. The Eco-Industrial Park is an opportunity to utilize the local work force's knowledge of energy and create new opportunity for economic development within the industrial park site.

\subsubsection{Transportation}

Mountain Top Industrial Park has rail service provided by CSX on an ex-Western Maryland branch line several miles from Mount Storm near Bayard, which transfers coal from an adjacent coal mine to Mount Storm Power Plant. East-west state highway 93 is located at the southern border of the project site. The western terminus of Route 93 is at WV 32 in Davis, Tucker County. The eastern terminus is at U.S. 50 southwest of Claysville, Mineral County. There are also some local roads that were used to connect former surface coal mines and Mount Storm Power Plant.

The proposed Corridor $\mathrm{H}$ alignment follows the present alignment of WV 93 east of the project site, and then crosses WV 93 just south of the industrial park to head for Tucker County which gives West Virginia a direct route to Washington DC over the Allegheny Mountains (Figure 11). The construction of the 16.1 mile stretch from Davis to Bismarck in Tucker and Grant Counties is underway (Figure 12). The construction of 6.2 miles of Corridor H, from the existing corridor at Bismarck in Grant County to the WV 93 connector at Mount Storm in Tucker County is anticipated to be completed in the Fall of 2014. The remaining 9.9 mile portion of the Davis to Bismarck section, from east of WV 32 to the WV 93 connector at Mount Storm is anticipated to be completed in the Summer of 2015 ("West Virginia Corridor H," 2003). Significant transportation will provide visitors with easy access to the Mountain Top Industrial Park and provide opportunities for its development as a gateway to the region. 


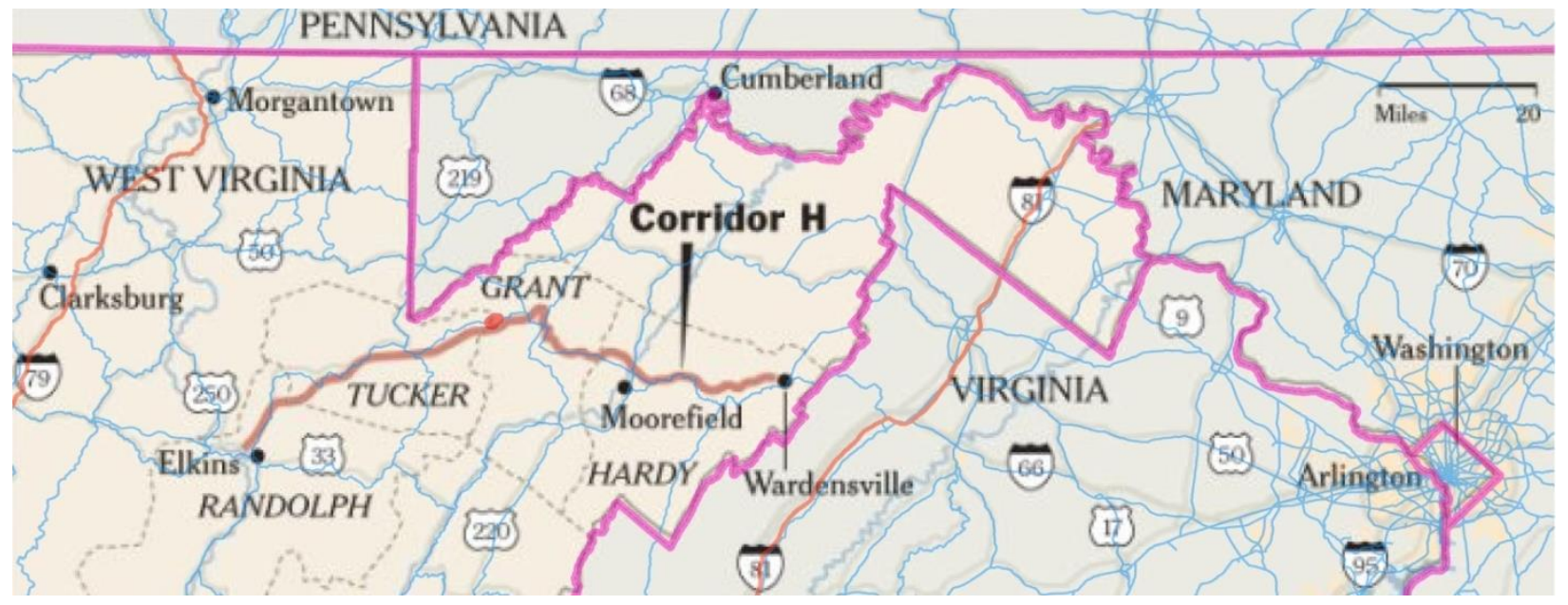

Figure 11. Entire Route of Proposed Corridor H

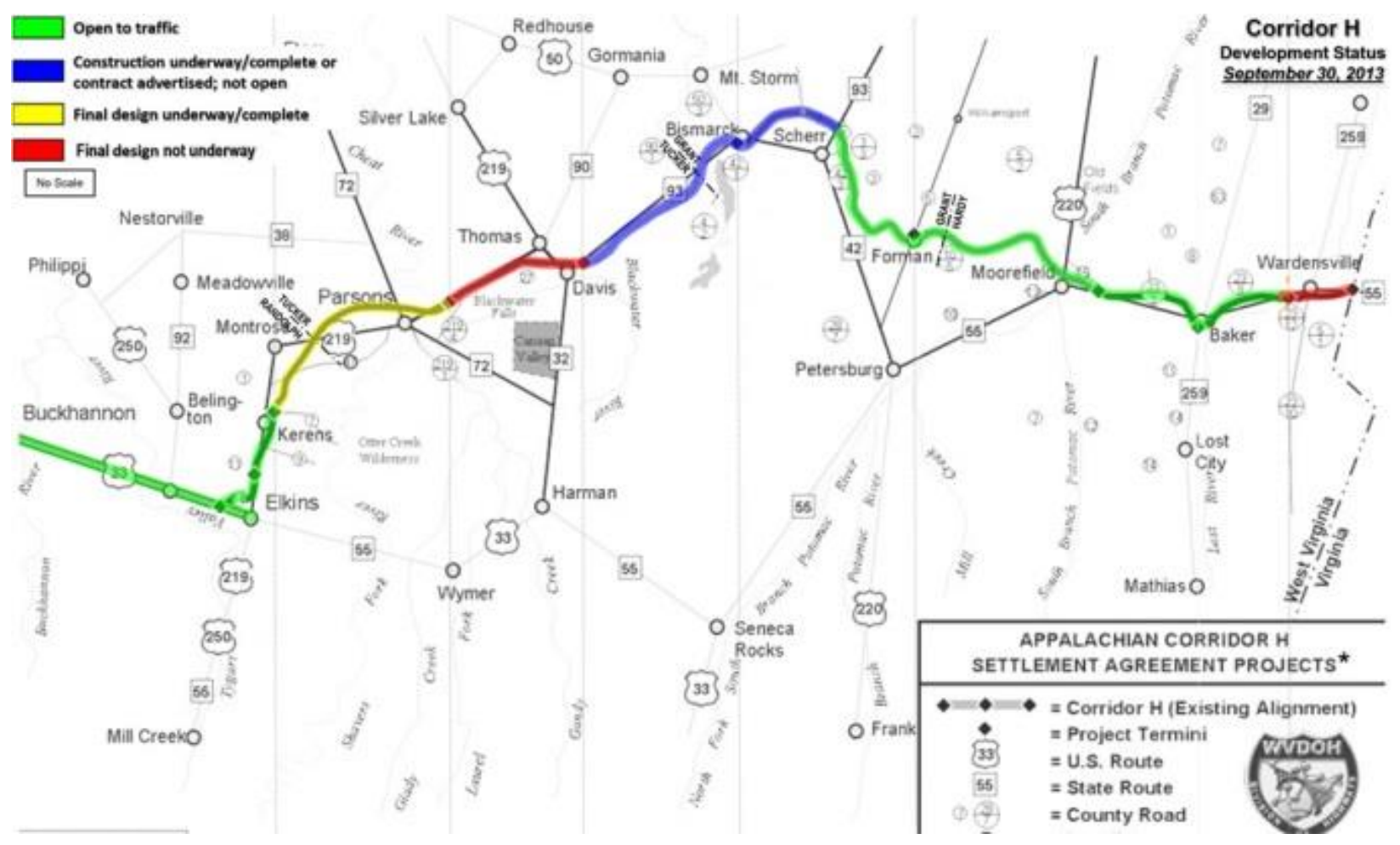

Figure 12. Construction Status of Proposed Corridor H 


\subsubsection{Former Coal Mines}

Mountain Top Industrial Park is surrounded by three former coal mines operated by ACI Coal Mining Company, Laurel Run Mining Company and Buffalo Mining Company. The coal mines are not active right now and some have been reclaimed including the Laurel Run coal mine at the northern border of the project site. It is very flat and covered by mine grass, which may potentially be planted with biomass for site redevelopment.

\subsubsection{Mount Storm Power Plant \& Trans-Allegheny Interstate Line (TrAIL)}

Mount Storm Power Plant is located on the west bank of Mount Storm Lake east of the project site, which is the largest coal-fired power station managed by Dominion Energy. Mount Storm Power Plant's three units can generate nearly 1,600 megawatts of electricity - as much in one hour as 160 average homes use in one year ("Mount Storm Power Station," 2013).

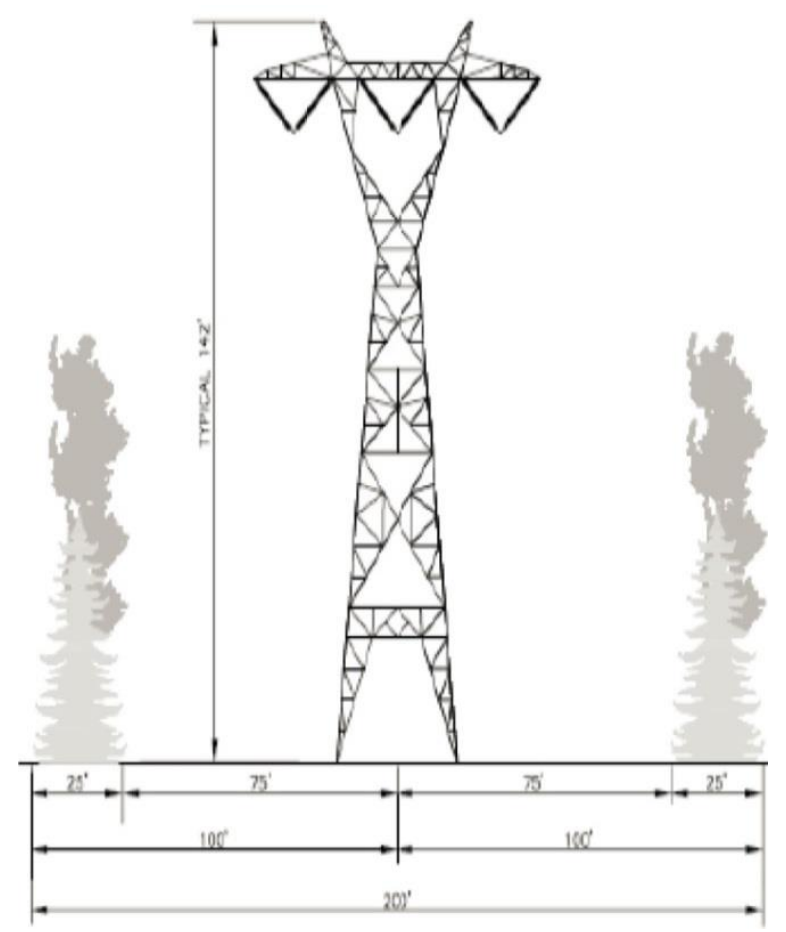

Figure 13. Clearance Zone for TrAIL Transmission Line

The TrAIL transmission line, a new 500-kilovolt (KV) line extends from southwestern Pennsylvania to an existing substation owned by Virginia Electric and Power Company at Mount Storm Lake. The line will cross the center of the industrial park property. TrAIL meets the 
demand for electricity in the Mid-Atlantic region and prevents overloading on Allegheny Power's transmission system. The right-of-way of TrAIL at Mountain Top Industrial Park is cleared to a width of 150 feet as deemed necessary for the safe and reliable operation of the line, which may potentially be planted with biomass for site redevelopment (Figure 13).

\subsubsection{Environmental Assessment}

The Mountain Top Industrial Park is a site adjacent to former surface coal mines. The forest at the western part of property is a mixture of mature hardwood species with rich nutrients. The vegetation at the eastern part of property can generally be described as successional, comprised mainly of grasses and forbs that are both native and invasive. Stormwater management would be a concern in the eastern area due to the flat topography and limited soil profile development.

\section{Vegetation}

Western forested areas are comprised of a mixture of hardwood species dominated by Allegheny-Cumberland dry oak forest \& hardwood species such as red and black oaks. Also present are some Appalachian cove forest species such as red maples (Acer rubrum) and yellow poplar (Liriodendron tulipifera). The eastern areas are open space without much vegetation, and area used for industrial purposes. Vegetation in this area can be described as successional pioneer species comprised of mainly grasses and forbs with some sparse native and invasive tree and shrub species.
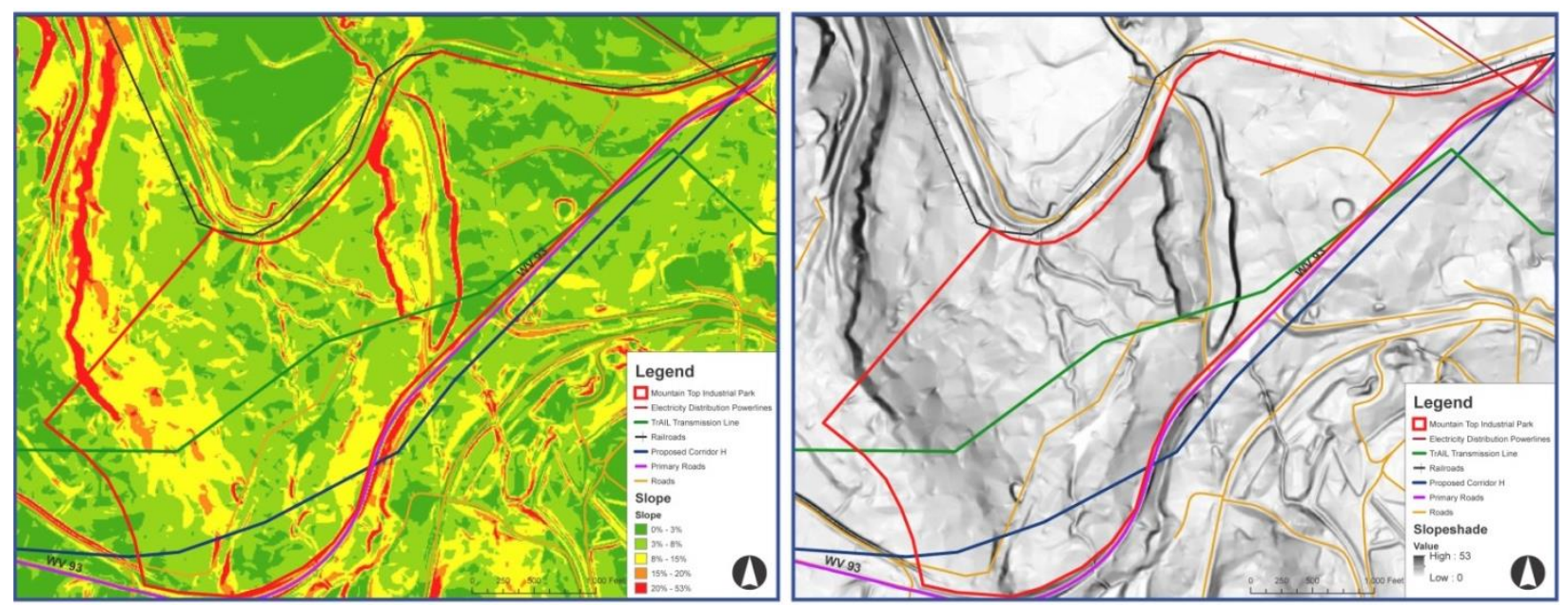

Figure 14. Slope \& Hillshade of Mountain Top Industrial Park 


\section{Hydrology}

The western part of the industrial park property's slope ranges from $8 \%$ to $20 \%$, making the area not suitable for redevelopment (Figure 14). Stormwater is flowing in the western part of the forest to two low points, which eventually discharge to a surface stream. The forest naturally manages stormwater, reduces flooding risk and improves water quality. The eastern part of the property is relatively flat, with slopes ranging from $0 \%$ to $8 \%$ (Figure 14). It is appropriate for redevelopment as a mixed-use site along Corridor H. Stormwater management is a concern in the eastern area because flat topography makes the stormwater runoff difficult to manage. Green infrastructure is needed to collect and clean stormwater. The stormwater flows from southwest to northeast.
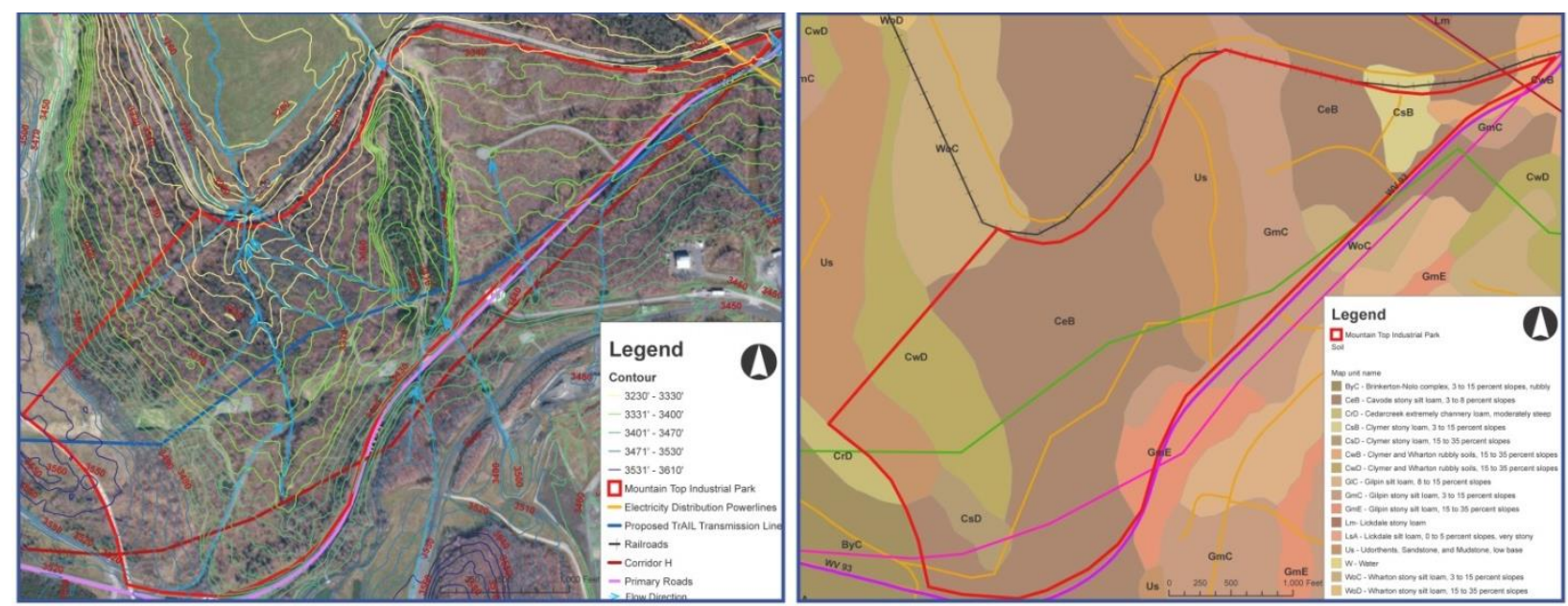

Figure 15. Topography \& Soil Types of Mountain Top Industrial Park

\begin{tabular}{|c|c|c|c|c|}
\hline MUSYM & Map Unit Name & Discription & Component & Typical Profile \\
\hline $\mathrm{CeB}$ & $\begin{array}{l}\text { CeB - Cavode stony silt loam, } \\
3 \text { to } 8 \text { percent slopes }\end{array}$ & $\begin{array}{l}\text { Gently sloping and somewhat poorly drained. } \\
\text { Stones cover } 1 \text { to } 3 \text { percent of the soil surface. }\end{array}$ & $\begin{array}{l}\text { Cavode and similar soils: } 70 \text { percent } \\
\text { Minor components: } 3 \text { percent }\end{array}$ & $\begin{array}{l}0 \text { to } 5 \text { inches: Silt loam } \\
5 \text { to } 60 \text { inches: Silty clay } \\
60 \text { to } 64 \text { inches: Bedrock }\end{array}$ \\
\hline CsB & $\begin{array}{l}\text { Cs B - Clymer stony loam, } 3 \text { to } \\
15 \text { percent slopes }\end{array}$ & $\begin{array}{l}\text { Gently sloping or strongly sloping and is well drained. } \\
\text { Stones cover } 1 \text { to } 3 \text { percent of the surface of soil. }\end{array}$ & Clymer and similar soils: 70 percent & $\begin{array}{l}0 \text { to } 6 \text { inches: Loam } \\
6 \text { to } 53 \text { inches: Channery sandy clay loam } \\
53 \text { to } 60 \text { inches: Channery sandy clay loam } \\
60 \text { to } 64 \text { inches: Bedrock }\end{array}$ \\
\hline CsD & $\begin{array}{l}\text { CsD - Clymer stony loam, } 15 \\
\text { to } 35 \text { percent slopes }\end{array}$ & $\begin{array}{l}\text { Moderately steep or steep and is well drained. } \\
\text { Stones cover } 1 \text { to } 3 \text { percent of the soil surface. }\end{array}$ & Clymer and similar soils: 75 percent & $\begin{array}{l}0 \text { to } 6 \text { inches: Loam } \\
6 \text { to } 53 \text { inches: Channery sandy clay loam } \\
53 \text { to } 60 \text { inches: Channery sandy clay loam } \\
60 \text { to } 64 \text { inches: Bedrock }\end{array}$ \\
\hline GmC & $\begin{array}{l}\text { GmC - Gilpin stony silt loam, } \\
3 \text { to } 15 \text { percent slopes }\end{array}$ & $\begin{array}{l}\text { Strongly sloping or gently sloping and is well drained. } \\
\text { Stones cover } 1 \text { to } 3 \text { percent of soil surface. }\end{array}$ & Gilpin and similar soils: 70 percent & $\begin{array}{l}0 \text { to } 5 \text { inches: Channery silt loam } \\
5 \text { to } 29 \text { inches: Channery silt loam } \\
29 \text { to } 35 \text { inches: Very channery silty clay } \\
\text { loam } \\
35 \text { to } 39 \text { inches: Unweathered bedrock }\end{array}$ \\
\hline WoC & $\begin{array}{l}\text { WoC - Wharton stony silt } \\
\text { loam, } 3 \text { to } 15 \text { percent slopes }\end{array}$ & $\begin{array}{l}\text { Strongly sloping or gently sloping and is moderately } \\
\text { well drained. } \\
\text { Stone cover } 1 \text { to } 3 \text { percent of surface soil. }\end{array}$ & $\begin{array}{l}\text { Wharton and similar soils: } 75 \text { percent } \\
\text { Minor components: } 2 \text { percent }\end{array}$ & $\begin{array}{l}0 \text { to } 6 \text { inches: Silt loam } \\
6 \text { to } 38 \text { inches: Silty clay loam } \\
38 \text { to } 58 \text { inches: Channery silt loam } \\
58 \text { to } 62 \text { inches: Bedrock }\end{array}$ \\
\hline
\end{tabular}

Figure 16. Soil Types Descriptions of Mountain Top Industrial Park Soils 
The majority of soils on the site can be characterized as compact rocky, gravely oxidized grey to silt loam mix (Figure 15). The eastern part of the property contains a stony/silt loam soil mix which would allow for some infiltration in that region of the site. Typically, the GmC soil is much rockier. It is anticipated that there will be much more permeability in this area and it may be redeveloped as a stormwater management area (Figure 16). Ph measurements on site ranged from 4.0 - 7.2. The area closer to former surface coal mines may be characterized as acidic. Due to the industrial land use without plant cover, soils in the eastern part of property are found to be poor in nutrients.

The western areas have retained soil nutrients to maintain secondary forest that were undisturbed, which allows stormwater to infiltrate the soil. These nutrients account in part for the nature of the vegetation, because the decaying organic matter from fallen vegetation or dead animals makes the soil that much richer.

\subsubsection{Summary from Environmental Inventory \& Analysis}

The site is best described and analyzed graphically in Summary from Inventory \& Analysis (Figure 17). The following will provide a summary of the site and important elements to consider during design.

The Mountain Top Industrial Park is at the center of an "energy" complex: Mount Storm Power Plant, NedPower Wind Farm and former surface mines. The eastern part of property is the development area (50 acres) for Mountain Top Industrial Park, which is around 50 acres along Corridor $\mathrm{H}$. The site is relatively flat, ranging from $0 \%$ to $8 \%$, which is good for development as a mixed - use area. The compacted soil has little nutrient value and is unable to infiltrate stormwater in most areas. Therefore, stormwater management will be a concern in redevelopment. The western part of property's slope range from $8 \%$ to $20 \%$, which is not suitable for redevelopment. It will be kept as existing forest. Biomass can be planted on the Laurel former surface coal mine and under the transmission line for site redevelopment.

In order to restore hydrologic function to the landscape, green infrastructure elements will be employed. These solutions will use natural functions to provide flood control, reduce solar heat gain, improve and stabilize the soil and create wildlife habitat by improving 
biodiversity. These systems may also infiltrate, evapo-transpire or reuse stormwater runoff, while improving water quality.

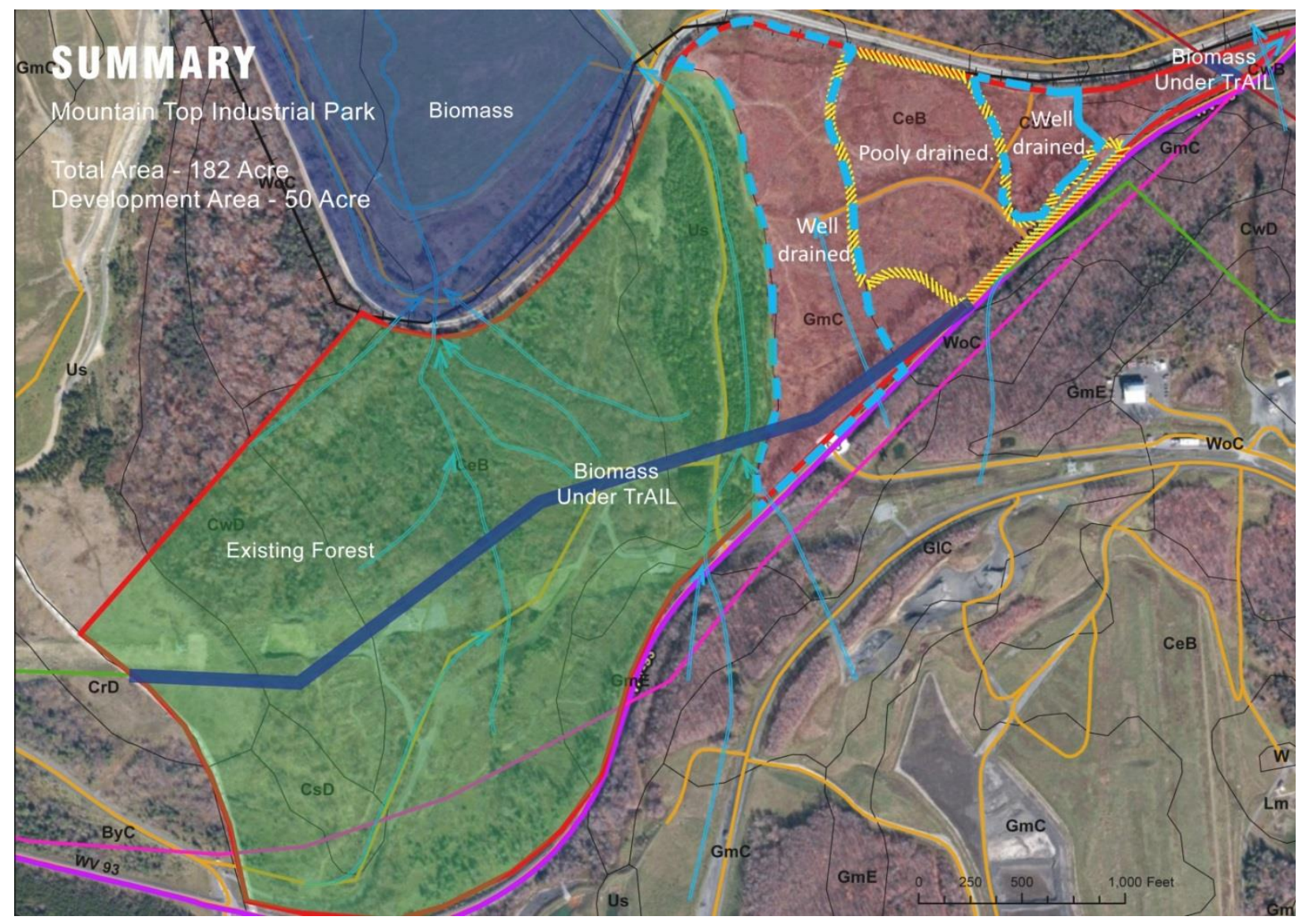

Figure 17. Summary from Environmental Inventory \& Analysis

\subsection{Clean Energy}

Clean energy is electricity generated from a renewable resource - such as wind, sunlight, methane from landfills, or sustainable biomass - that emits little or no pollution in the generation process. In contrast, fossil fuels like coal, oil, and gas aren't considered clean because of the pollution associated with their extraction from the earth and with the combustion process used to generate the power.

\section{$>$ Why Clean Energy?}

Much of the electricity supplied to American homes today is generated by burning fossil fuels. Switching to clean energy sources helps to: 
- Reduce the amount of fossil fuel.

- Reduce pollution and greenhouse gases.

- Boost the renewable energy market and increase regional demand for clean energy.

- Generate new jobs and revenue in clean energy generation, transmission, and installation.

- Reduce your personal environmental footprint.

\section{How Much Does Clean Energy Cost?}

At present, clean energy supplied by local utilities costs the consumers about the same as "standard" power (electricity generated by traditional sources such as oil and coal). Historically, renewable energy sources haven't received the same government subsidies and support as coal, oil, and gas to cover the costs of production and transportation. Therefore, renewable energy generators have had to set higher prices to cover their production expenses. In the long term, clean energy supplied by local utilities will cost less than "standard" power. Price estimates for standard electricity and for electricity from a clean energy source demonstrate this fact. The relative environmental impact of the two types of electricity generation are also shown in Figure 18("Clean Energy: The Basics - Montgomery County MD," 2012).

\begin{tabular}{|c|c|c|c|}
\hline & $\begin{array}{c}\text { Cost per } \\
\text { Kilowatt-hour } \\
(\mathbf{k W h})\end{array}$ & $\begin{array}{c}\text { Total Cost per } \\
\text { Month }(\mathbf{1}, \mathbf{0 0 0} \mathbf{~ k W h})\end{array}$ & Environmental Impact \\
\hline $\begin{array}{c}\text { Average monthly cost for } \\
\text { standard electricity }\end{array}$ & $\$ 0.1192$ & $\$ 119.20$ & $\begin{array}{c}1,293 \mathrm{lb} \text { carbon dioxide, 8lb sulfur } \\
\text { dioxide, 31b nitrogen dioxide }^{\mathrm{b}}\end{array}$ \\
\hline $\begin{array}{c}\text { Average monthly cost for } \\
\text { 100\% wind power }\end{array}$ & $\$ 0.1170$ & $\$ 117$ & 0 \\
\hline
\end{tabular}

Figure 18. Price Estimates from Traditional Energy \& Clean Energy

\section{How Does Clean Energy Get to Your Home?}

The transfer of energy from its generating source to homes is shown in Figure 19 ("Clean Energy: The Basics - Montgomery County MD," 2012). Like "standard" power, electricity generated from wind, solar, biomass and other sources is transferred to the energy grid. The local utility company or clean energy supplier purchases power from the electricity generators. This electricity is transmitted through the grid to your area and the utility company distributes it to your home. 


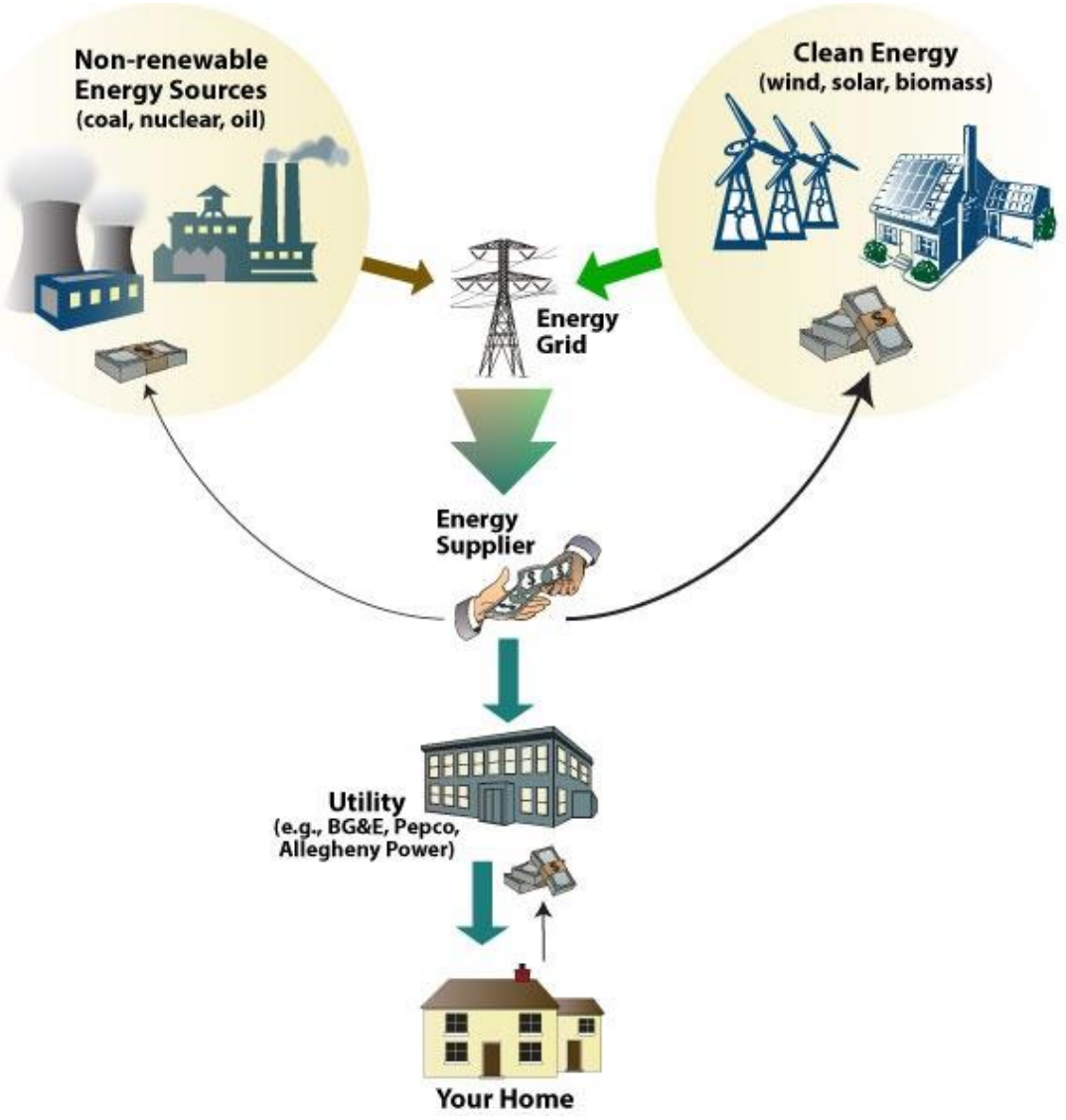

Figure 19. Energy Moves from Energy Generators to Your Home.

\subsubsection{Bioenergy}

Bioenergy is produced from living organisms from metabolic byproducts (organic or food waste products) using three basic pathways: Corn-based ethanol, oilseed-based biodiesel, or cellulosic ethanol made from wood waste or perennial grass.

Bioenergy, most notably corn-based ethanol, has grown as a component of United States' motor fuel supply, which could have significant consequences for traditional U.S. agricultural crop production. Corn ethanol has been around since the 1970s, but national production is going up fast and costs are coming down. Also this can be a new way for Mountain Top Industrial Park to make use of a variety of agricultural raw material produced as waste throughout the region. Agriculture is still a significant source of employment and land use within this region of West Virginia and adjacent counties in Maryland. Taking advantage of existing agricultural areas 
in close proximity creates an opportunity for biofuel generated sustainable energy, which will help to reduce greenhouse gas emissions (Yacobucci \& Schnepf, 2007).

Another way of making biofuels will be from perennial grass production in West Virginia and Maryland. Some perennial grasses have been shown to tolerate poor soils and drought, and have been tested for the revegetation of surface mine sites. Unlike corn-based ethanol, perennial grass ethanol returns 5.5 times more energy than input into the process. In addition, perennial grass produces more biomass than other products and provides enhanced wildlife habitat for many species such as deer, turkey, and songbirds. Mountain Top Industrial Park has many advantages for growing perennial grass for biofuel. It is along major transportation corridors such as Route 93, Corridor H, CSX railroad and the TrAIL transmission line that is suitable for perennial grass cultivation.

\section{Why Bioenergy at Mountain Top Industrial Park}

Mountain Top Industrial Park is located in the Appalachian region. Adjacent counties have abundant biomass resources, which provide opportunities to utilize and convert these materials to bioenergy (Figure 20).

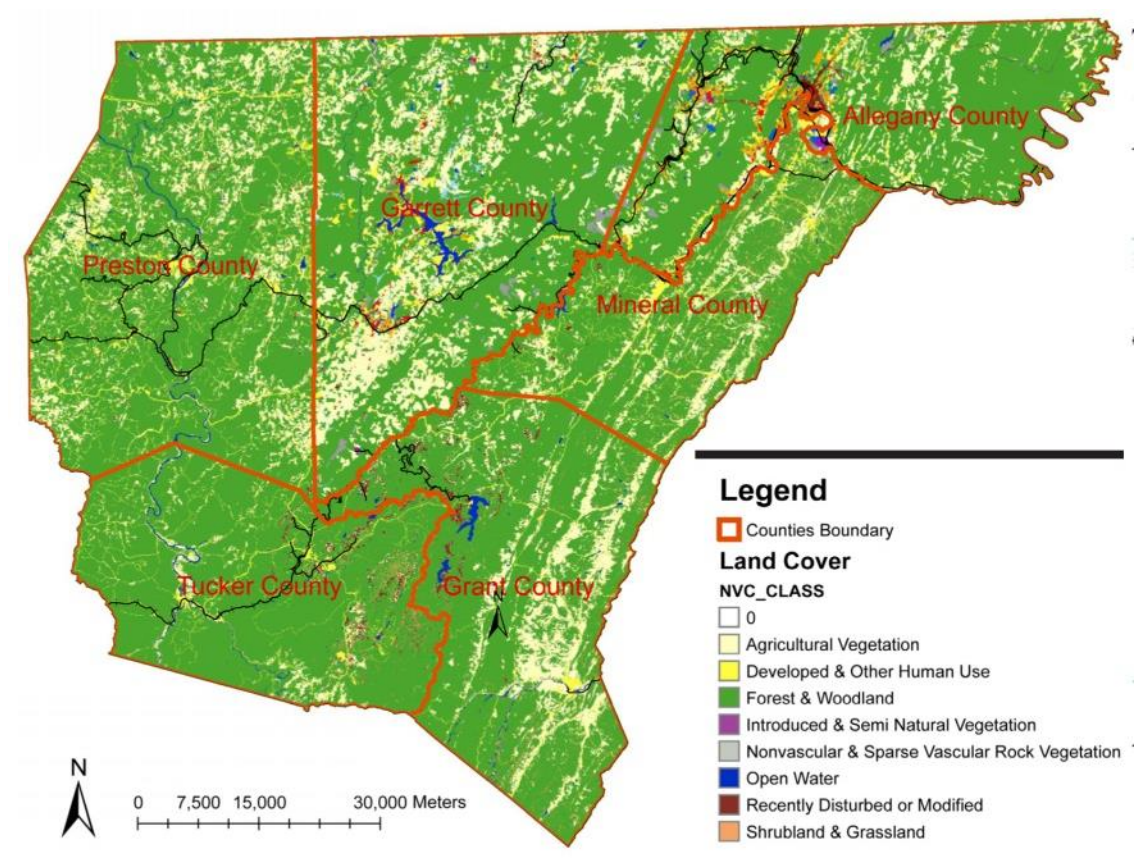

Figure 20. Regional Land Cover 
Bioenergy is a good choice for the site also because of abundant water supplies for ethanol processing, abundant rainfall and a long, warm growing season. Proximity to the railroad (170 kilometer Western Maryland Railroad and 190 kilometer Baltimore \& Ohio Railroad) running through adjacent counties and Mount Storm Power Station creates the opportunity for the industrial park to be a biomass processing center (Figure 21).

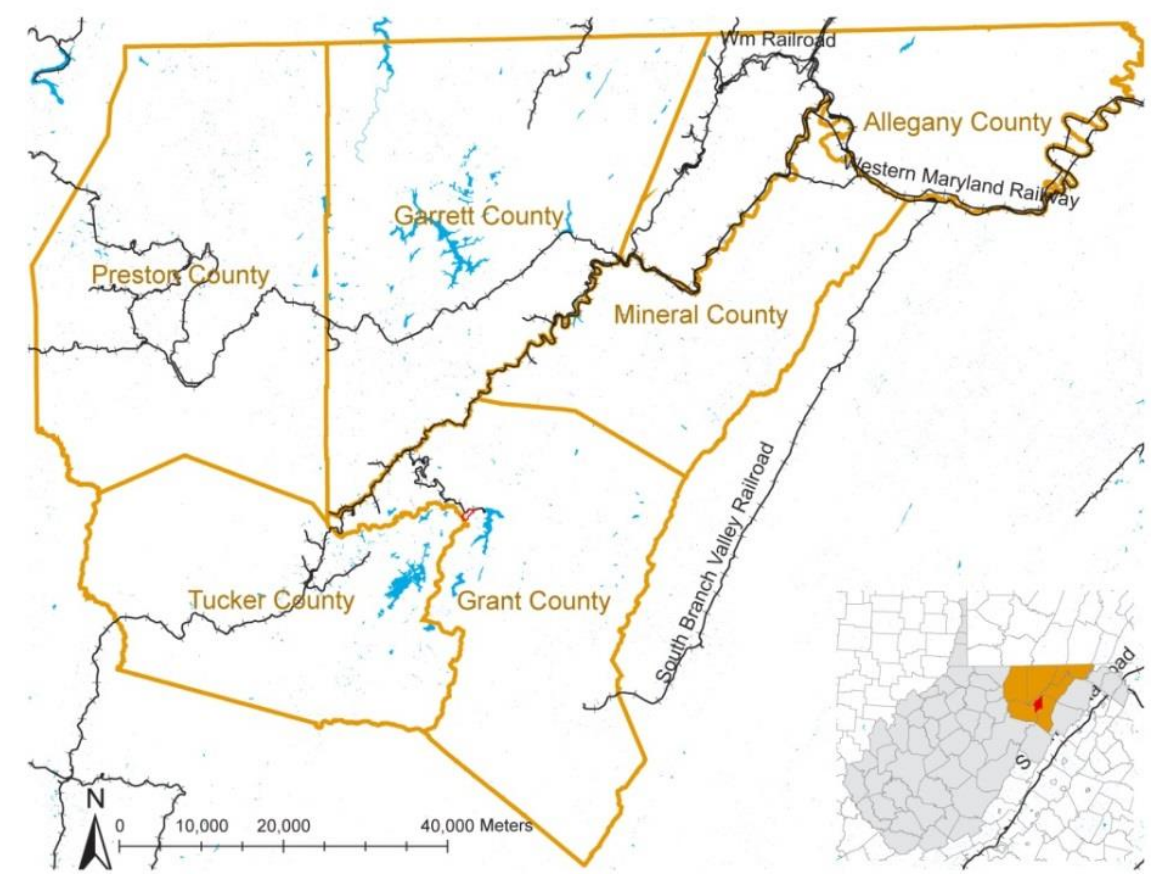

Figure 21. Proximity to Railroad \& Mount Storm Power Station

\section{Co-firing Biomass with Coal at Mount Strom Power Station}

Co-firing is the burning of more than one type of fuel simultaneously. Usually, the term is used to describe the combination of coal with another fuel source. Mount Storm Power Station is a coal-fired power station owned by Dominion. Co-firing biomass is a good option for Mount Storm Power Station for the following reasons:

- The solid biomass fuel can be added to the fuel stream.

- The addition of biomass to the fuel reduces emissions of sulfur.

- Biomass fuel is essentially carbon neutral. 
However, challenges associated with biomass co-firing for Mount Storm Power Station, include:

- Handling and storage challenges for Mount Storm Power Station.

- The potential for fouling and slagging at high co-firing rates (Ciolkosz, 2010).

Therefore, Mountain Top Industrial Park can be redeveloped as a biomass processing center to handle and store biomass for Mount Storm Power Plant. The additional issue of storage at Mount Storm Power Station will need to be resolved. 


\section{Economic Profile}

Income indicators for adjacent counties are mixed but generally low. The average wage per job for these six counties was less than the state average and the national average in 2011. Especially for Tucker County and Garrett County, it was substantially below the state and national average. Grant, Mineral and Preston Counties did have a lower poverty rate than the state of West Virginia as a whole; however, the poverty rates were still somewhat higher than the national individual poverty rate (Table 1).

Table 1. Demographics and Economic Profile for Grant, Tucker County, Preston County, Mineral County, Garrett County, Allegany County, WV, MD and U.S. ("STATS America,")

\begin{tabular}{|c|c|c|c|c|c|c|c|c|c|}
\hline People \& Income Overview & Grant County, WV & Tucker County, WV & Preston County, wV & Mineral County, wV & Garrett County, MD & Allegany County, MD & West Virginia & Maryland & U.S. \\
\hline Population (2012) & 11,816 & 6,995 & 33,832 & 27,956 & 29,854 & 74,012 & $1,855,413$ & $5,884,563$ & $313,914,040$ \\
\hline Growth (\%) Since 2000 & $4.60 \%$ & $-4.50 \%$ & $15.30 \%$ & $15.80 \%$ & $0.00 \%$ & $-1.20 \%$ & $2.60 \%$ & $11.10 \%$ & $11.54 \%$ \\
\hline Growth (\%) Since 1990 & $13.30 \%$ & $-9.50 \%$ & $16.50 \%$ & $13.80 \%$ & $6.10 \%$ & $-1.20 \%$ & $3.50 \%$ & $23.10 \%$ & $26.20 \%$ \\
\hline Land Area (in sq. miles) & 477.4 & 418.9 & 648.8 & 329 & 647.1 & 424.2 & $24,038.20$ & 9,707 & $3,531,905$ \\
\hline Population Density (2012) & 24.8 & 16.7 & 52.1 & 83 & 46.1 & 174.5 & 77.2 & 606.2 & 88.9 \\
\hline \% Reporting One Race Onl & $99.00 \%$ & $98.80 \%$ & $98.30 \%$ & $96.16 \%$ & $99.30 \%$ & $98.10 \%$ & $97.90 \%$ & $96.90 \%$ & $96.80 \%$ \\
\hline Households & 4,915 & 3,215 & 12,908 & 11,276 & 12,410 & 28,596 & 740,080 & $2,128,377$ & $114,761,359$ \\
\hline Labor Force & 5,079 & 2,739 & 15,794 & 13,636 & 17,385 & 36,996 & 799,883 & $3,072,246$ & $153,617,000$ \\
\hline Unemployment Rate & 11 & 10.7 & 7 & 7.4 & 7.5 & 8.5 & 8 & 7 & 8.9 \\
\hline Per Capita Personal Incom & 30162 & 28837 & 28197 & $\$ 31,733$ & $\$ 38,463$ & $\$ 32,855$ & $\$ 33,403$ & $\$ 50,656$ & $\$ 41,560$ \\
\hline Poverty Rate & 17.6 & 19.2 & 15.8 & 17.2 & 15.1 & 17.1 & 18.2 & 9.9 & 15.3 \\
\hline \multicolumn{10}{|l|}{ Industry Overview (2011) } \\
\hline Covered Employment & 3,799 & 2,401 & 6,870 & 7,835 & 11,323 & 29,242 & 701,905 & $2,478,505$ & $129,411,095$ \\
\hline Avg Wage Per Job & 39,323 & 25,267 & 34,830 & 35,959 & 30,850 & 34,285 & 39,092 & 53,008 & 48,043 \\
\hline Manufacturing & $6.80 \%$ & $10.50 \%$ & $7.00 \%$ & $23.00 \%$ & $9.30 \%$ & $8.60 \%$ & $7.00 \%$ & $4.60 \%$ & $9.10 \%$ \\
\hline Transportatio & $3.00 \%$ & $0.60 \%$ & $3.20 \%$ & $2.90 \%$ & $3.70 \%$ & $2.80 \%$ & $3.00 \%$ & $3.10 \%$ & $3.90 \%$ \\
\hline Health Care, Social Assist & $13.00 \%$ & $11.80 \%$ & $10.90 \%$ & N/A & N/A & $20.80 \%$ & $18.40 \%$ & $13.90 \%$ & $14.20 \%$ \\
\hline Finance and Insurance & $2.70 \%$ & $2.40 \%$ & $2.40 \%$ & $1.70 \%$ & N/A & $2.50 \%$ & $2.70 \%$ & $3.80 \%$ & $4.30 \%$ \\
\hline
\end{tabular}


Grant and Tucker Counties have seen the unemployment level spike to two of the highest in the state and higher than the national average. Garrett County and Allegany County did have a lower rate than the national average. However, they were still higher than the Maryland state average. Grant, Tucker, Preston, Mineral, Garrett and Allegany Counties' unemployment levels are high compared to other counties (Figure 22).
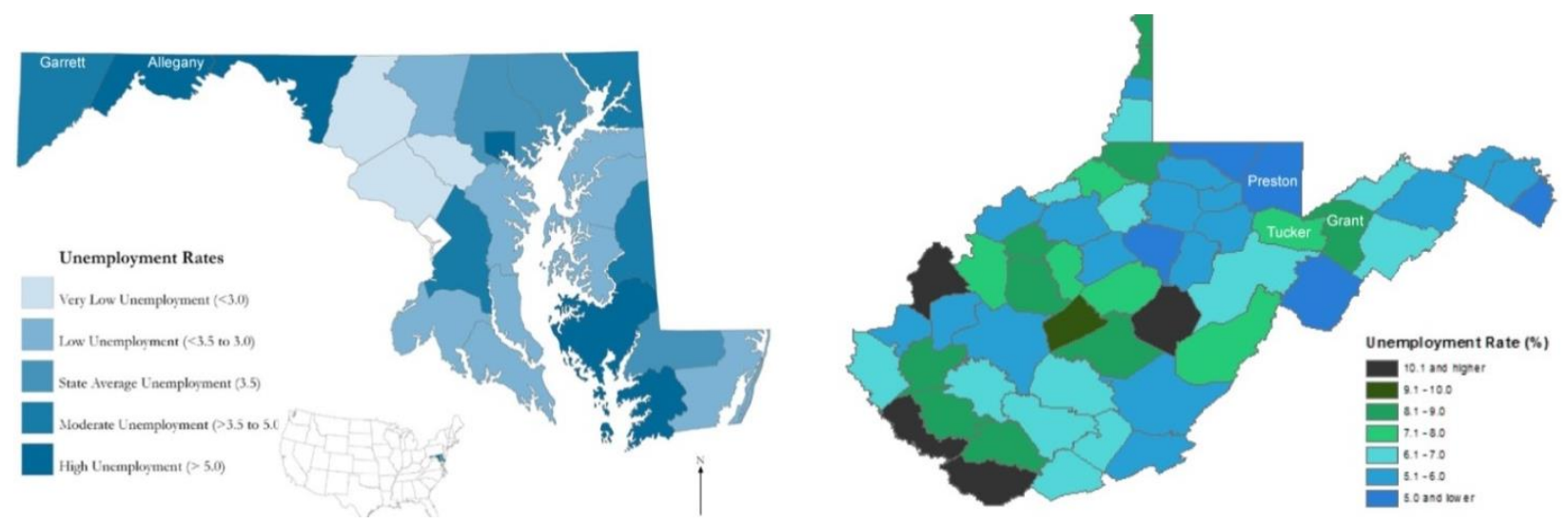

Figure 22. Unemployment Rate for Maryland \& West Virginia

\section{Economic Benefits}

- Make a substantial, positive impact on local and regional economies by generating wellpaying jobs in construction and operation of the plant, collection and transportation of biomass material.

- Support local industry and businesses and encourage new investment in the adjacent counties.

Biomass energy facilities can help stabilize the local timber and forestry industry by providing stable demand for biomass material, which allows loggers, harvesters, processors and transporters to make capital investments. Biomass facilities also increase the local tax base without requiring substantial services from the local community. With the biomass resource, Grant, Tucker, Preston, Mineral, Garrett and Allegany Counties has the potential to produce 0.65 billion $\mathrm{kWh}$ of electricity from biomass, which is enough to supply power to 66,000 average homes. Bioenergy could make a profit of 0.06 billion dollars (Table 2). 
Table 2. Bioenergy Economic Benefits from Grant, Tucker, Preston, Mineral, Garrett and Allegany Counties (Wang, Grushecky, \& McNeel, 2007)

\begin{tabular}{|c|c|c|c|c|c|c|}
\hline BIOMASS PRODUCTION & Grant County, WV & Tucker County, WV & Preston County, WV & Mineral County, WV & Garrett County, MD & Allegany County, MD \\
\hline Wood Residues & _- & _ & _ & _ & - & _ \\
\hline Logging Residue & $\begin{array}{l}\text { Annual Harvest } 3206 \text { - } 4670 \text { Acres } \\
\text { Production } 33.34 \text { - } 48.56 \mathrm{~K} \text { dry tons } \\
\text { Available } 7,875 \text { dry tons }\end{array}$ & $\begin{array}{l}\text { Annual Harvest } 1878-3206 \text { Acres } \\
\text { Production } 19.53-33.34 \mathrm{~K} \text { dry tons } \\
\text { Available } 11,618 \text { dry tons }\end{array}$ & $\begin{array}{l}\text { Annual Harvest } 7053-10598 \text { Acres } \\
\text { Production } 73.35-110.21 \mathrm{k} \text { dry tons } \\
\text { Available } 35,631 \text { dry tons }\end{array}$ & $\begin{array}{l}\text { Annual Harvest } 561-1878 \text { Acres } \\
\text { Production } 5.83-19.53 \mathrm{~K} \text { dry tons } \\
\text { Available 4,309 dry tons }\end{array}$ & 50-100 Thousand Dry Tons/Year & 25-50 Thousand Dry Tons/Year \\
\hline Mill Residue & Availabe 2,600 - 5,200 Tons/Year & Availabe $0-2,600$ Tons/Year & Availabe 0 - 2,600 Tons/Year & Availabe $0-2,600$ Tons/Year & _ & $>100$ Thousand Dry Tons/Year \\
\hline Urban Tree Residue & $<5$ Thousand Dry Tons/Year & $<5$ Thousand Dry Tons/Year & $<5$ Thousand Dry Tons/Year & $<5$ Thousand Dry Tons/Year & $<5$ Thousand Dry Tons/Year & 5-10 Thousand Dry Tons/Year \\
\hline Pallet Residue & No Wood Pallet Facility & 1 Wood Pallet Facility & No Wood Pallet Facility & 3 Wood Pallet Facilities & 3 Wood Pallet Facilities & 3 Wood Pallet Facilities \\
\hline Agriculture Residues & - & _- & $<20$ Thousand Dry Tons/Year & _- & $<20$ Thousand Dry Tons/Year & $<20$ Thousand Dry Tons/Year \\
\hline Grass Seed Straw & - & _- & - & - & - & - \\
\hline Corn & $<2,500$ Dry Tons/Year & $<2,500$ Dry Tons/Year & 3,910 Dry Tons/Year & $<2,500$ Dry Tons/Year & _ & _ \\
\hline Soybean Residue & $<2,700$ Dry Tons/Year & $<2,700$ Dry Tons/Year & $<2,700$ Dry Tons/Year & $<2,700$ Dry Tons/Year & _ & _ \\
\hline All Hay & 20,000 - 50,000 Dry Tons/Year & 5,000 - 20,000 Dry Tons/Year & 62,300 Dry Tons/Year & 20,000 - 50,000 Dry Tons/Year & _ & _ \\
\hline $\begin{array}{l}\text { Switchgrass } \\
\text { Perennial Crops }\end{array}$ & $\begin{array}{l}\text { \& Hay } 12,800-17,700 \text { Acres } \\
\text { Potential switchgrass yield } 8,000 \text { - } \\
10,000 \text { dry tons }\end{array}$ & $\begin{array}{l}\text { Hay } 4,200 \text { - } 8,700 \text { Acres } \\
\text { Potential switchgrass yield 2,000 - } \\
5,000 \text { dry tons }\end{array}$ & $\begin{array}{l}\text { Hay } 17,700 \text { - } 31,200 \text { Acres } \\
\text { Potential switchgrass yield } 10,000 \text { - } \\
19,438 \text { dry tons }\end{array}$ & $\begin{array}{l}\text { Hay } 12,800 \text { - } 17,700 \text { Acres } \\
\text { Potential switchgrass yield } 8,000 \text { - } \\
10,000 \text { dry tons }\end{array}$ & - & - \\
\hline Animal Manure & $<250$ Tons/Year & _ & $<250$ Tons/Year & $<250$ Tons/Year & $<250$ Tons/Year & $<250$ Tons/Year \\
\hline $\begin{array}{l}\text { Construction } \\
\text { Demolition Wastes }\end{array}$ & - & - & - & - & - & - \\
\hline Total & $<50$ Thousand Tons/Year & $<50$ Thousand Tons/Year & 100 - 150 Thousand Tons/Year & 50 - 100 Thousand Tons/Year & 50-100 Thousand Dry Tons/Year & 150-250 Thousand Dry Tons/Year \\
\hline Grand Total & \multicolumn{4}{|c|}{400 Thousand Tons/Year } & & \\
\hline $\begin{array}{l}\text { kWh of Electricity } \\
\text { from Biomass }\end{array}$ & \multicolumn{6}{|c|}{$\begin{array}{l}\text { Protential to produce } 0.65 \text { billion } \mathrm{kWh} \text { of electricity from biomass, which make a profit of } 0.06 \text { billion. } \\
\text { It is enough to supply power to } 66,000 \text { average homes. }\end{array}$} \\
\hline
\end{tabular}




\subsubsection{Wind Energy}

Wind power, as an alternative to fossil fuels, is renewable, clean, produces no greenhouse gas emissions during operation and uses little land. A wind turbine is a device that converts wind power into electricity with propeller-like blades mounted on a tower. Based on site conditions, different turbine designs can be used to meet different electricity needs. The smallest turbines are used for community-scale generation; while large grid-connected arrays of turbines are becoming an increasingly important source of wind power produced commercial electricity.

\section{$>$ Wind Resources at Mountain Top Industrial Park}

The wind resources in the Mountain Top Industrial Park are in the range of 6 to 8 meters/second $(\mathrm{m} / \mathrm{s})$ at an altitude of 80 meters on an average annual basis ("AWS Truepower," 2010) (Figure 23). The wind speed is a critical feature of wind resources, which can be used to generate electricity by different wind turbine sizes. The addition of Mountain Top Industrial Park to the Ned Power Mount Storm Wind Power Farm would provide energy to the country through wind energy.

The Mountain Top Industrial Park contains enough acreage to site two to four turbines. The modeled turbine layout is shown below in Figure 24, with each turbine 500 meters apart on a north-south line and 750 meters apart on an east-west line. This arrangement considers a maximum number of turbines that could be deployed.

However, the property has three significant physical constraints that may limit the number of turbines to two: a rail line comprising the northern border of the property, a state road comprising the southern and eastern border, and an east-west high-voltage transmission line traversing the center of the property. This analysis evaluates one potential project representing an 8 Megawatt (MW) wind facility owned by a wind developer or local/developer partnership. The array is comprised of four $2 \mathrm{MW}$ turbines. 


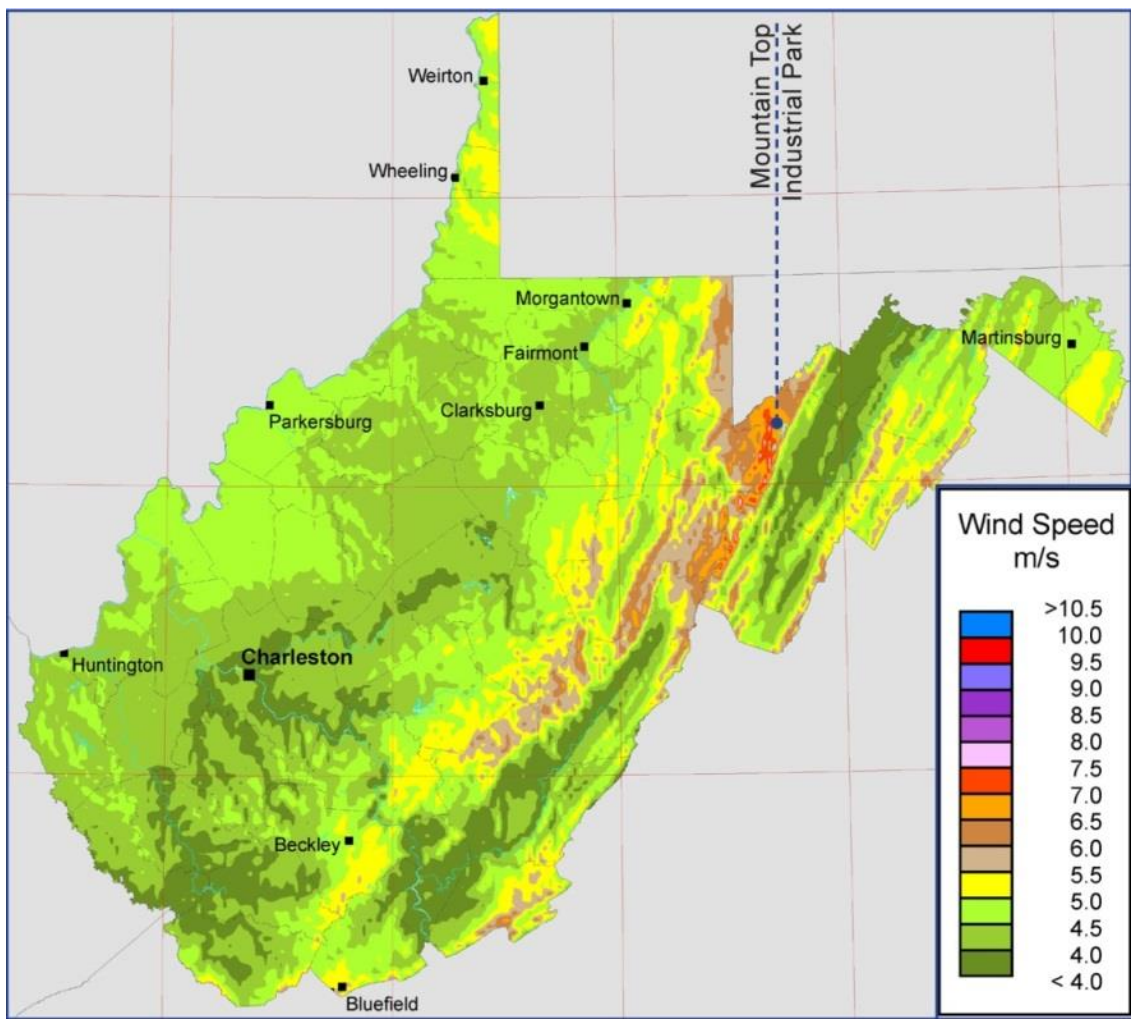

Figure 23. Wind Resources at Mountain Top Industrial Park

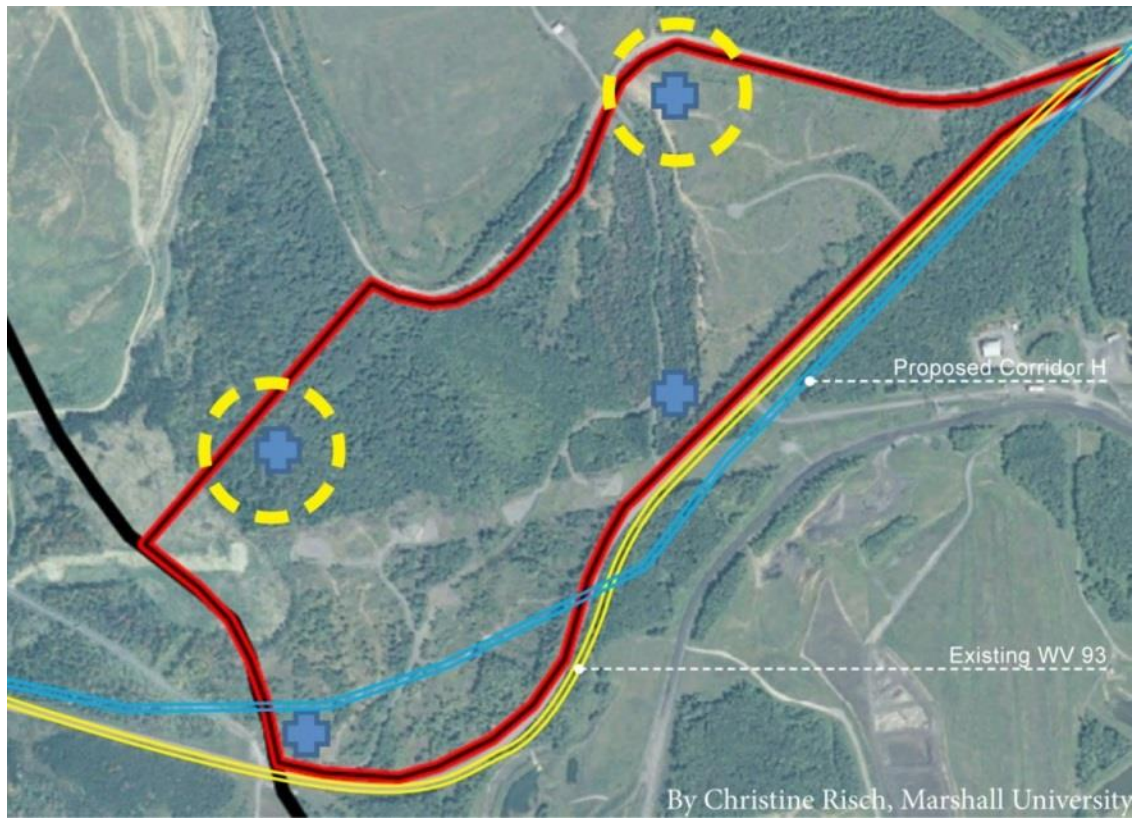

Figure 24. Wind Turbines Layout in Mountain Top Industrial Park 


\section{Economic Benefits}

The wind resource analysis was modeled by Prof. Christine Risch of the Center for Business and Economic Research at Marshall University (SBAC) at two potential average wind speeds: $7.3 \mathrm{~m} / \mathrm{s}$ and $7.7 \mathrm{~m} / \mathrm{s}$ - at an altitude of 100 meters, which represents the higher height of the newer towers. The expected output of the facility is shown in Figure 25. On an annual basis the capacity factor of the facility is expected to be around $29 \%$.

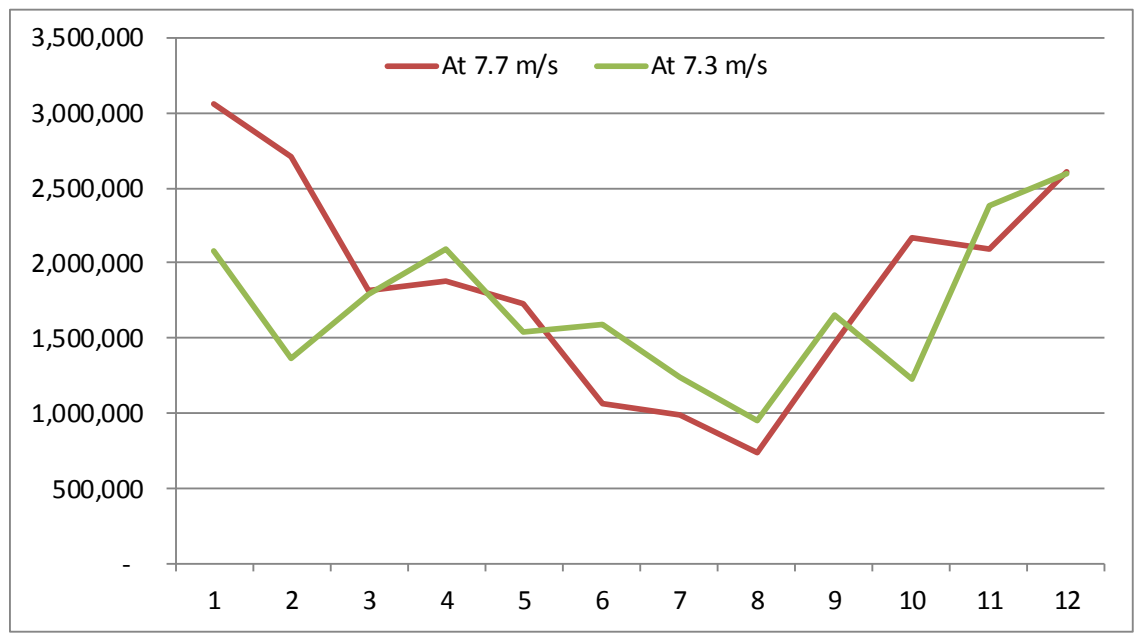

Figure 25. Monthly Estimated Energy Output at 7.7 and $7.3 \mathrm{~m} / \mathrm{s}$

The primary direct economic impacts associated with a wind facility would be seen during the construction phase. The majority of the construction impact would be from installation labor and support services as well as wholesale trade. During the operating phase the facilities would require only two full-time people, or less. These estimated impacts are described below and are based on the JEDI model ("National Renewable Energy Laboratory," 2011)

- Construction phase: 16 direct construction jobs +22 indirect support jobs +9 induced jobs for a total of 47 temporary jobs.

- Operating phase: 2 full-time jobs, including indirect effects

While the direct economic impacts of the facility to the region will be small following construction, there may be additional benefits at the community level. These include productive use of marginal land that would otherwise be unused and maintenance of that land for future uses. 
The community is already familiar with wind facilities, given the presence of two other utilityscale plants in the area (Risch, 2013).

\section{Solar Energy}

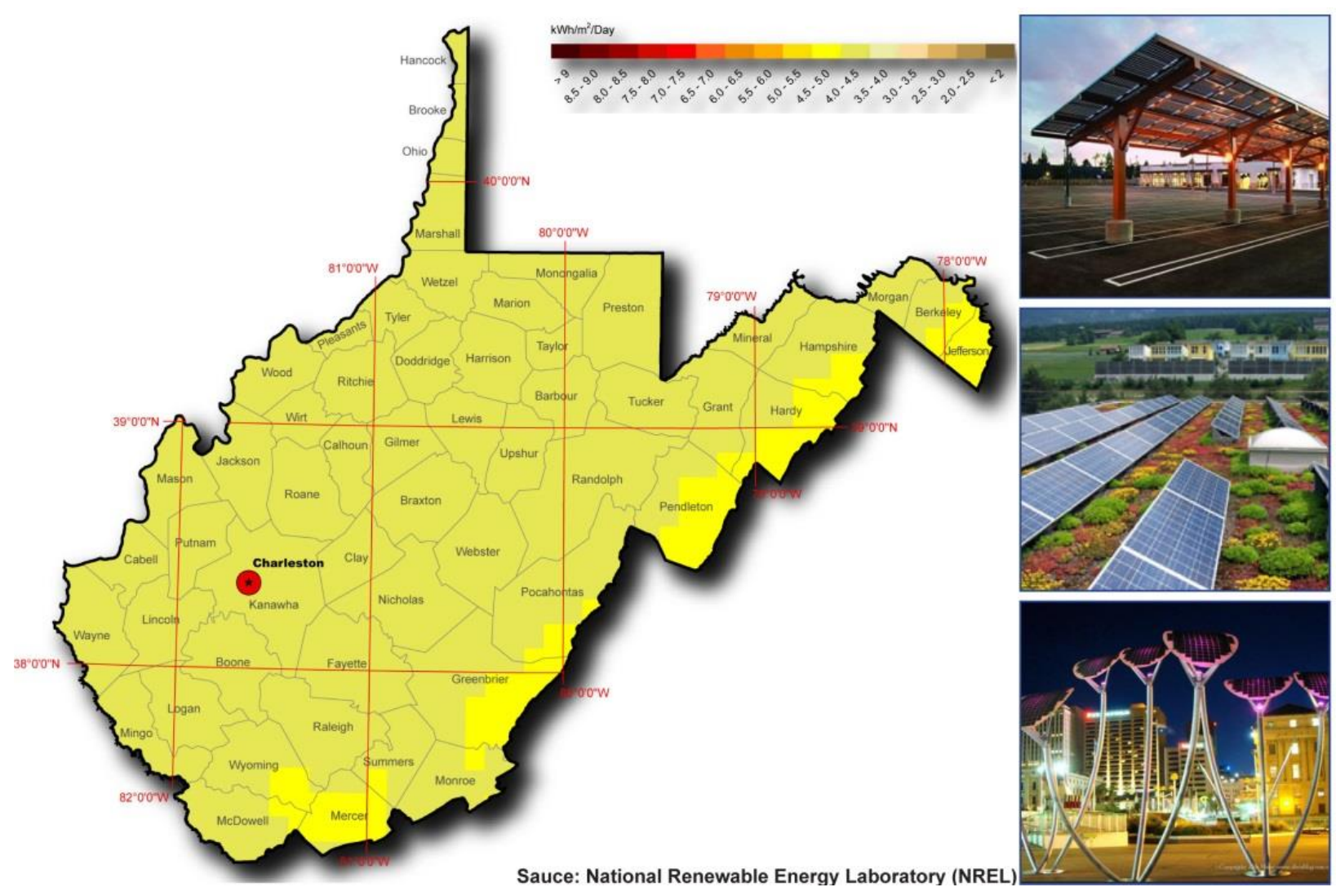

Figure 26. Solar Resources at Mountain Top Industrial Park

Available solar energy is comparable in West Virginia to neighboring states. Solar power on rooftops can provide $11 \%$ of all electricity used in West Virginia ("Solar power in West Virginia," 2013). A study concentrating on solar energy at National Renewable Energy Laboratory's Renewable Resource Data Center (Figure 26) found that around 4.0 - 4.5 kilowatt hours/square meter/day is available at Mountain Top Industrial Park. Solar energy, thermal and photovoltaic, can be used on industrial and commercial buildings in the Mountain Top Industrial Park. In order to capture the greatest amount of solar energy, panels need to be southerly facing. For thermal solar, passive solar can be used to complement heating systems and the concentrated rays of the sun can be used to heat a fluid to steam - generating high temperatures, and driving a steam turbine electric generator. Photovoltaic energy is different from thermal energy, which 
converts solar radiation into direct current electricity using solar panels composed of a number of solar cells.

Solar canopies within parking lots and solar tree lights may be installed in the property. This will turn parking lots into solar power plants and solar tree lights will create additional space for power generation where there might not have been adequate roof or ground space. In addition, because they are built vertically, over land already in use, they limit the environmental impact on the landscape. Positioning solar power systems in parking areas and on streets can address objections to the projects based on aesthetic or architectural grounds.

\subsection{Approach}

\subsubsection{Green Infrastructure}

Green Infrastructure is an approach to restore and sustain ecological values and functions. Green infrastructure generally refers to systems and practices that use or mimic natural processes through a collecting system of open space, parks, wetlands, healthy streams and infiltration. These initiatives have the potential to filter air and water pollutants, provide flood control, reduce solar heat gain, enhance and stabilize soil and provide wildlife habitat, building biodiversity while improving human health and strengthening people's connection to nature and sense of place. Green Infrastructure is effective, economical, and enhances community safety and quality of life.

\section{$>$ Green Roofs}

Green roofs replace conventional roofing materials with a living, breathing vegetated roof system. A green roof consists of a layer of vegetation over a growing medium on top of a waterproof membrane. Green roofs significantly decrease stormwater runoff by detaining and evaporating stormwater on site. Green roofs have the ability to reduce total runoff by $60 \%$ and can detain $85 \%$ of the peak flow depending on the depth of the growing medium. In addition, green roofs save energy, filter pollutants, provide food and habitat for wildlife, create green spaces, improve aesthetics, and provide educational opportunities.

There are two types of green roofs according to their depth and maintenance requirement: intensive and extensive. Intensive roofs are designed to provide outdoor places for recreation and 
generally more expensive due to engineering requirement, a deeper soil medium, and the need for accessibility("Green Roof -- System Types," 2003). Intensive roofs can be used to create park space and agricultural areas. Extensive roofs are typically inaccessible and are less expensive to construct and maintain. Therefore they will be a likely choice for most of the building development in Mountain Top Industrial Park. With only 6" of soil, lower plant diversity, these low growing species can be easily installed using modular pre-vegetated mats or trays. A green roof cross-section is shown in Figure 27.

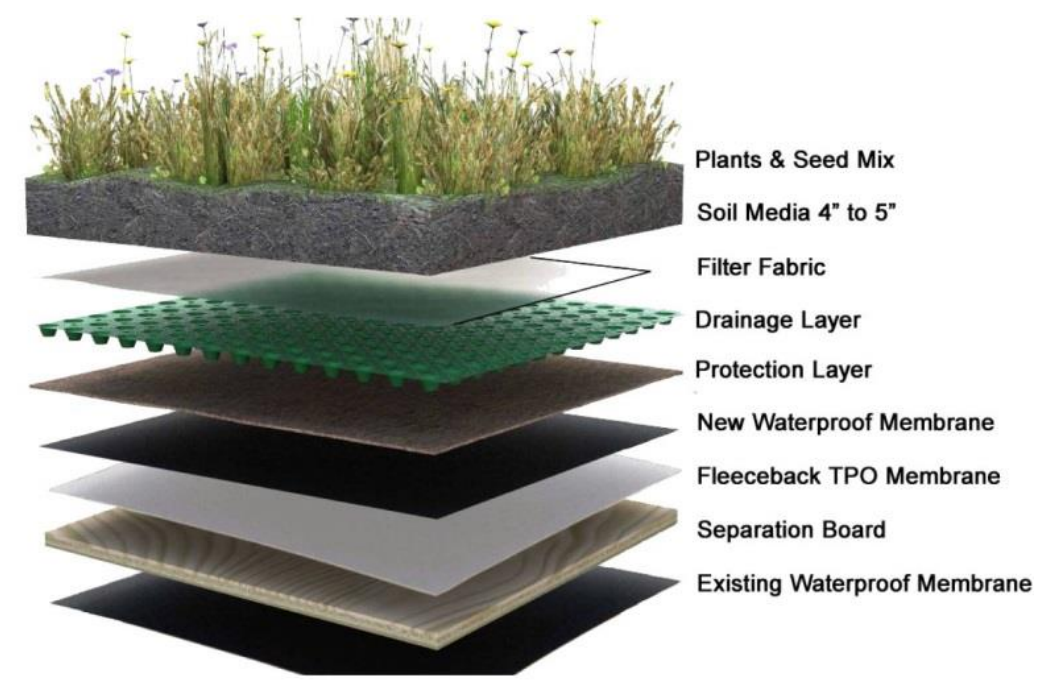

Figure 27. Typical Extensive Green Roof Cross - Section

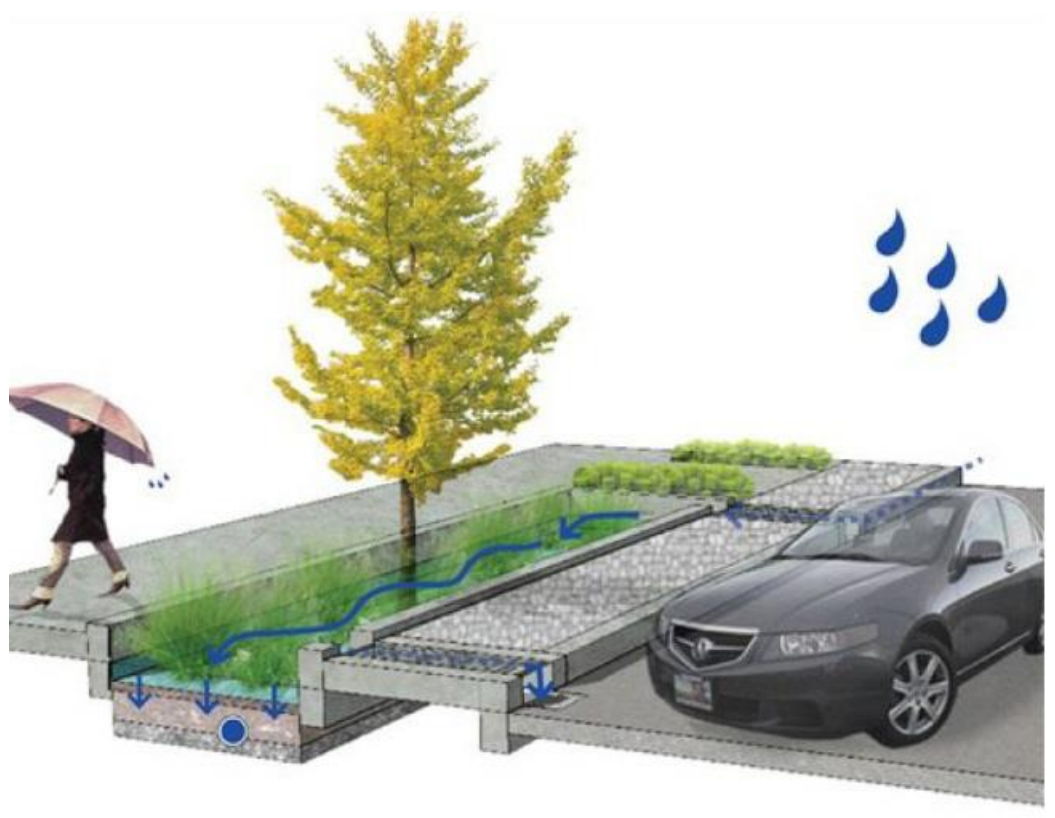

Figure 28. Bioretention System on Street 


\section{$>$ Green Streets}

Green streets are vegetated curb extensions, streetside planters, or infiltration basins (rain gardens) that collect stormwater runoff from streets. Green streets reduce stormwater flow to sewers, reduce pollutants and limit erosion in urban streams, provide wildlife habitat and neighborhood green spaces, and refresh groundwater supplies.

Bioretention is designed in Mountain Top Industrial Park to slow down and collect water to reduce runoff (Figure 28). Green streets have the ability to reduce total runoff by $93 \%$ of the peak flow. Water from the driveways will be channeled to Bioretention while permeable paved sidewalks and driveways will allow for more water infiltration into the ground than traditionally paved surfaces, thus capturing water more naturally and relieving the burden of runoff on local streams that often can result in flooding.

\section{$>$ Trees}

Trees protect watershed health by absorbing rain (which restores hydrology) and preventing erosion (which protects water quality and habitat). In this way, trees are a vital, longterm, and low-cost component of green infrastructure for managing stormwater. Trees also clean the air, create restorative spaces, provide cooling shade and wildlife habitat. Street trees can improve property values and slow traffic, making streets safer for pedestrians, bike riders, and motorists.

\subsubsection{Summary of Benefits}

This section provides a summary of the benefits estimated through the expert panel process and follow - up construction.

Table 3 summarizes the benefits relating to health, energy and community livability, which based on currently available data and research ("Portland's Green Infrastructure: Quantifying the Health, Energy, and Community Livability Benefits," 2010). The data are both qualitative and quantitative; some benefits such as energy savings were more easily quantified that other benefits, such as those related to community cohesion or health. 
Table 3. Benefits of Green Infrastructures

\begin{tabular}{|c|c|c|c|c|c|c|c|c|c|}
\hline & \multicolumn{3}{|c|}{ Health } & \multicolumn{2}{|r|}{ Energy } & \multicolumn{4}{|c|}{ Community Livability } \\
\hline & $\begin{array}{l}\text { Air Quality } \\
\text { Improvement }\end{array}$ & $\begin{array}{l}\text { Increased } \\
\text { Greenness }\end{array}$ & $\begin{array}{c}\text { Slow } \\
\text { Stormwater }\end{array}$ & $\begin{array}{l}\text { Energy } \\
\text { Savings }\end{array}$ & $\begin{array}{l}\text { Greenhouse Gas } \\
\text { Reduction }\end{array}$ & $\begin{array}{l}\text { Aesthetics } \\
\text { Improvement }\end{array}$ & $\begin{array}{l}\text { Community } \\
\text { Cohesion }\end{array}$ & $\begin{array}{c}\text { Environmental } \\
\text { Equity }\end{array}$ & $\begin{array}{l}\text { Access to } \\
\text { Nature }\end{array}$ \\
\hline Green Roofs & $\begin{array}{l}7.7 \mathrm{lbs} / \\
\text { acre /year }\end{array}$ & $\begin{array}{l}\text { Associated with } \\
\text { improved physical } \\
\text { and mental health }\end{array}$ & $\begin{array}{l}60 \% \text { peak flow } \\
\text { reduction }\end{array}$ & $\begin{array}{l}8,270+ \\
\text { kWh/Acre }\end{array}$ & $\begin{array}{l}7.1 \text { metric tonnes } \\
\text { / acre /year }\end{array}$ & $\begin{array}{l}\text { Possible positive } \\
\text { effect }\end{array}$ & $\begin{array}{l}\text { Possible positive } \\
\text { social capital effect, } \\
\text { no known effect } \\
\text { on crime }\end{array}$ & $\begin{array}{l}\text { Possible positive } \\
\text { effect }\end{array}$ & $\begin{array}{l}\text { Magnitude is } \\
\text { dependent on } \\
\text { the number of } \\
\text { people with views } \\
\text { of or access to } \\
\text { the green roofs. }\end{array}$ \\
\hline Green Streets & $\begin{array}{l}0.04 \text { lbs / } \\
\text { facility /year }\end{array}$ & $\begin{array}{l}\text { Associated with } \\
\text { improved physical } \\
\text { and mental health }\end{array}$ & $\begin{array}{l}93 \% \text { peak } \\
\text { flow reduction }\end{array}$ & $\begin{array}{l}155+ \\
\text { kWh/facility }\end{array}$ & $\begin{array}{l}0.3 \text { metric tonnes } \\
\text { / facility /year }\end{array}$ & $\begin{array}{l}\text { Positive, 3\% to } 5 \% \\
\text { increase in home } \\
\text { values }\end{array}$ & $\begin{array}{l}\text { Increase social } \\
\text { capital, decrease } \\
\text { crime }\end{array}$ & $\begin{array}{l}\text { Possible positive } \\
\text { effect }\end{array}$ & $\begin{array}{l}2,000 \text { pedestrians } \\
\text { /day walkable } \\
\text { areas, and } 600 \\
\text { pedestrians in } \\
\text { less walkable } \\
\text { areas }\end{array}$ \\
\hline Trees & $\begin{array}{l}0.2 \mathrm{lbs} / \\
\text { tree /year }\end{array}$ & $\begin{array}{l}\text { Associated with } \\
\text { improved physical } \\
\text { and mental health }\end{array}$ & $\begin{array}{l}10 \% \text { reduction } \\
\text { in flow rates }\end{array}$ & $\begin{array}{l}11+ \\
\mathrm{kWh} / \text { tree }\end{array}$ & $\begin{array}{l}0.1 \text { metric tonnes } \\
\text { / tree /year }\end{array}$ & $\begin{array}{l}\text { Likely positive } \\
\text { effect }\end{array}$ & $\begin{array}{l}\text { Possible positive } \\
\text { social capital effect, } \\
\text { no known effect on } \\
\text { crime }\end{array}$ & $\begin{array}{l}\text { Possible positive } \\
\text { effect }\end{array}$ & $\begin{array}{l}\text { 2,000 pedestrians } \\
\text { /day walkable } \\
\text { areas, and } 600 \\
\text { pedestrians in } \\
\text { less walkable } \\
\text { areas }\end{array}$ \\
\hline
\end{tabular}




\subsubsection{Wetlands Types}

Stewart and Kantrud (1971) developed a classification of wetland based on the vegetation found in the deepest zone of wetland basins (Galatowitsch \& Valk, 1994). There are five different vegetation types in freshwater wetlands: wet prairie, sedge meadow, shallow marsh, deep marsh, and permanent open water (Figure 29).

- Type 1: ephemeral ponds with a central wet prairie zone

- Type 2: temporary ponds with a central sedge meadow zone

- Type 3: seasonal ponds and lakes with a central shallow marsh zone dominated by bulrushes and other emergent marsh plants

- Type 4: semi-permanent ponds and lakes with a central deep marsh zone

- Type 5: permanent ponds and lakes with a central permanent open water zone

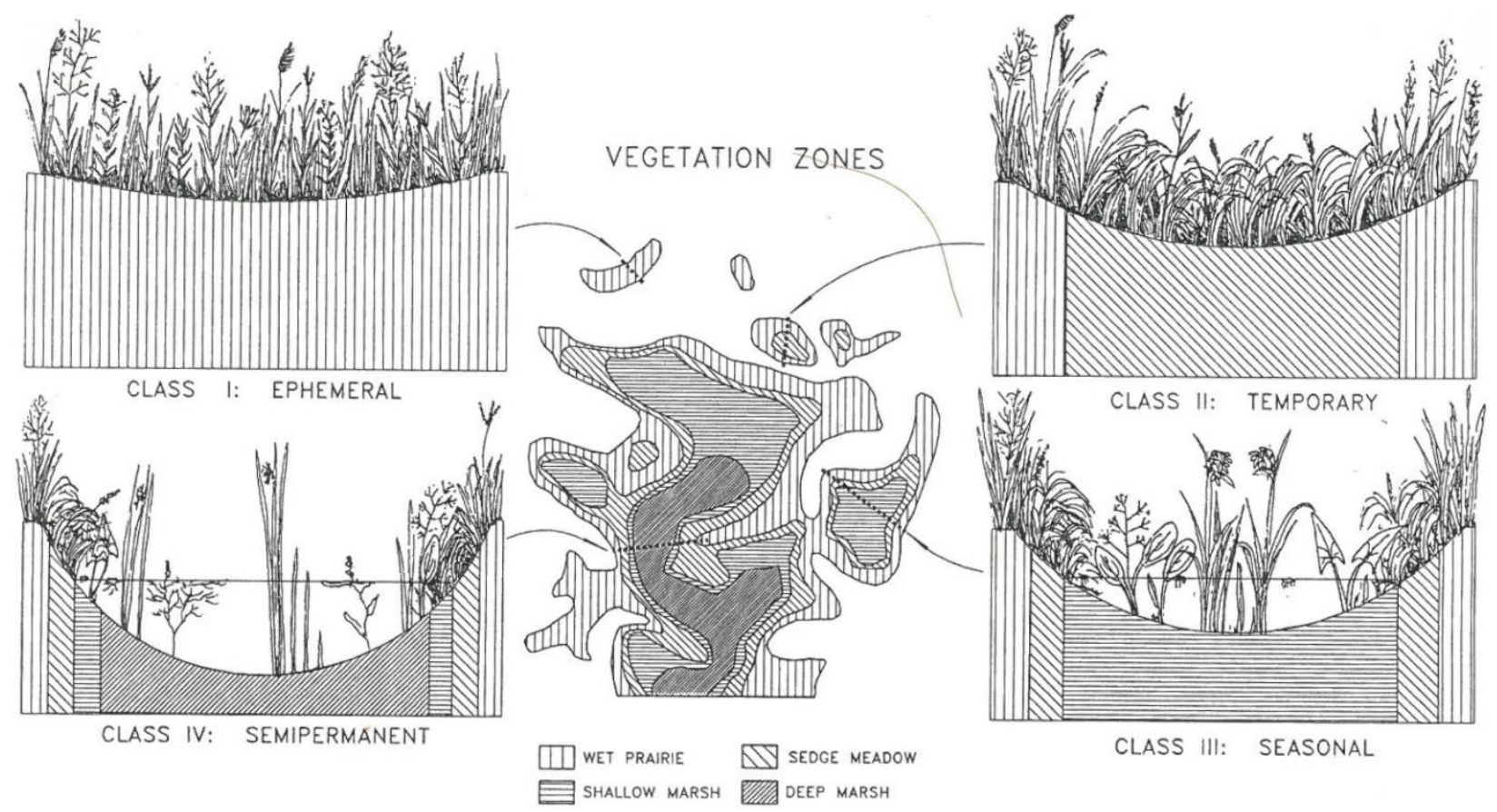

Figure 29. Wetland Types and Their Associated Wetland Zones

Sedge meadows (Type 2) will be applied in Mountain Top Industrial Park, which have a periphery of wet prairie and a central area generally dominated by several of many possible types of sedge such as woolly sedge, green bulrush along with grasses such as bluejoint and prairie 
cord grass. The wetland not only collects stormwater, filters air and water pollutants, but also provides wildlife habitat, and build biodiversity.

\subsubsection{Mixed-use Development}

In addition to green infrastructure, mixed-use development will encourage more compact, walkable development in Mountain Top Industrial park. Mixed use developments contain a complementary mix of uses such as residential, retail, commercial, employment, civic and entertainment uses in close proximity - sometimes in the same building. Benefits of mixed-use development include:

- Allows for greater housing variety and density

- Reduces distances between housing, workplaces, retail businesses, and other destinations

- Encourages more compact development

- Promotes pedestrian and bicycle friendly environments

The location and topography of Mountain Top Industrial Park makes the area suitable for mixed-use development. Proposed Corridor H connecting to Washington DC will bring more visitors to this region. Therefore, the property will be the gateway to many recreational destinations. A welcome center and education programs would match new development to current trends in education-based tourism. More commercial and retail will be needed to serve growing numbers of visitors. In addition to commercial and recreational opportunities, a Biomass Processing Center on site would meet the requirements of Grant County Economic Development Council project for bringing more businesses to the area.

\section{Recreation Gateway}

- Welcome center offers valuable information and services for travelers to Davis, Thomas and Mount Storm Lake, as well as the region.

- Museums will focus on "Energy" storytelling. The unique indoor \& outdoor museums offer educational opportunities for the community to learn about traditional energy (surface mining) and sustainable energy.

- A walking tour of an adjacent surface mine will provide opportunities to learn about surface mine history and the equipment used in the process will be displayed on site. The 
instructor would be a real coal miner who will share some mining tales and answer any questions.

- Beaver Creek Trail will give visitors the opportunity to hike or bike from Mountain Top Industrial Park to Davis, WV, and nearby conservation lands full of beautiful forests and abundant wildlife.

\section{Commercial \& Retail}

The mix of retail and commercial will bring economic development from outside the community, which will meet the goals of Grant County Economic Development Council.

- A sports store will provide diving, swimming, fishing, shooting and camping supplies, which will also bring a full line of training, instruction, education, equipment and services.

- A convenience store and gas station, will provide long shopping hours. It will stock a range of everyday items such as groceries, toiletries, alcoholic and soft drinks, tobacco products, and newspapers to meet the needs of visitors.

- Small retail businesses and restaurants will be located in Mountain Top Industrial Park. Some shops and restaurant chains, including Chinese food, Indian food, KFC, Café Latte, Pizza Hot and other options will serve growing numbers of visitors to the region.

\section{Biomass Processing Center}

Wood waste, sawdust and crop waste will be collected from Grant, Tucker, Preston, Mineral, Garrett and Allegany counties by railroad and stored in Mountain Top Industrial Park. Then they will be burned in Mount Storm Power Plant, which creates electricity and distributes it to transmission lines.

\subsection{Summary from Inventory \& Analysis}

\subsubsection{Weaknesses}

- Depopulation and lost economic drivers caused by the declination of coal industry. 
- Core environmental problem- at the center of Mount Storm Power Plant and former surface mines

- Strongly acidic soil limits the selection of plants.

\subsubsection{Threats}

- TrAIL $(500 \mathrm{KV})$ is traversing the center of the property. Safety will be a concern in site redevelopment.

\subsubsection{Strengths}

- Significant transportation - Railroad CSX and WV 93 in the border of the property; proposed expressway Corridor $\mathrm{H}$ will provide visitors with easy access to the region.

- Many recreational destinations and abundant biomass resources nearby.

\subsubsection{Opportunities}

- Develop clean energy - biomass, wind, solar energy, which will generate new jobs and revenue in clean energy generation, transmission and collection.

- Mixed-use development along Corridor H.

- Tourism gateway to the region.

- Green infrastructure encouraging more compact, walkable park space.

The location of the existing industrial park, in close proximity to the CSX railroad, a future expressway Corridor H, Mount Storm Power Plant and natural resources, lends itself to be envisioned as an eco-industrial park and may function as a gateway to the region. The site is at the center of an 'energy' complex: Mount Storm Power Plant and former surface mines. Extractive industries and energy production will be a theme within the design project. The site development will also serve as an educational resource to local schools, universities and business groups. 


\section{Chapter 3. Concept Design}

\subsection{Case Studies}

Sites that inspired or contained similar elements for the eco-industrial parks were studied in order to gain a general understanding of the design process, implementation and success of development methods. The following sites served as case studies: Qunli Stormwater Park, TaigalNova Eco-Industrial Park and Renewable Energy Education Park.

\subsubsection{Qunli Stormwater Park - Haerbin City, China}

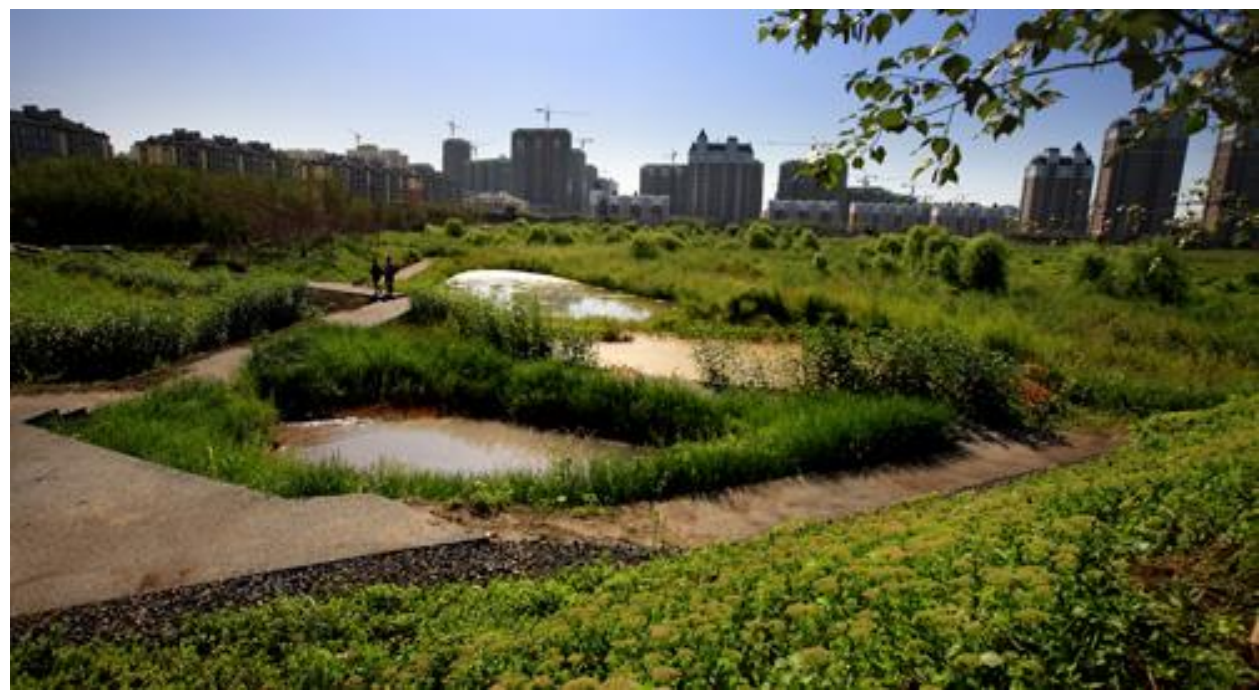

Figure 30. Central Part of the Wetland

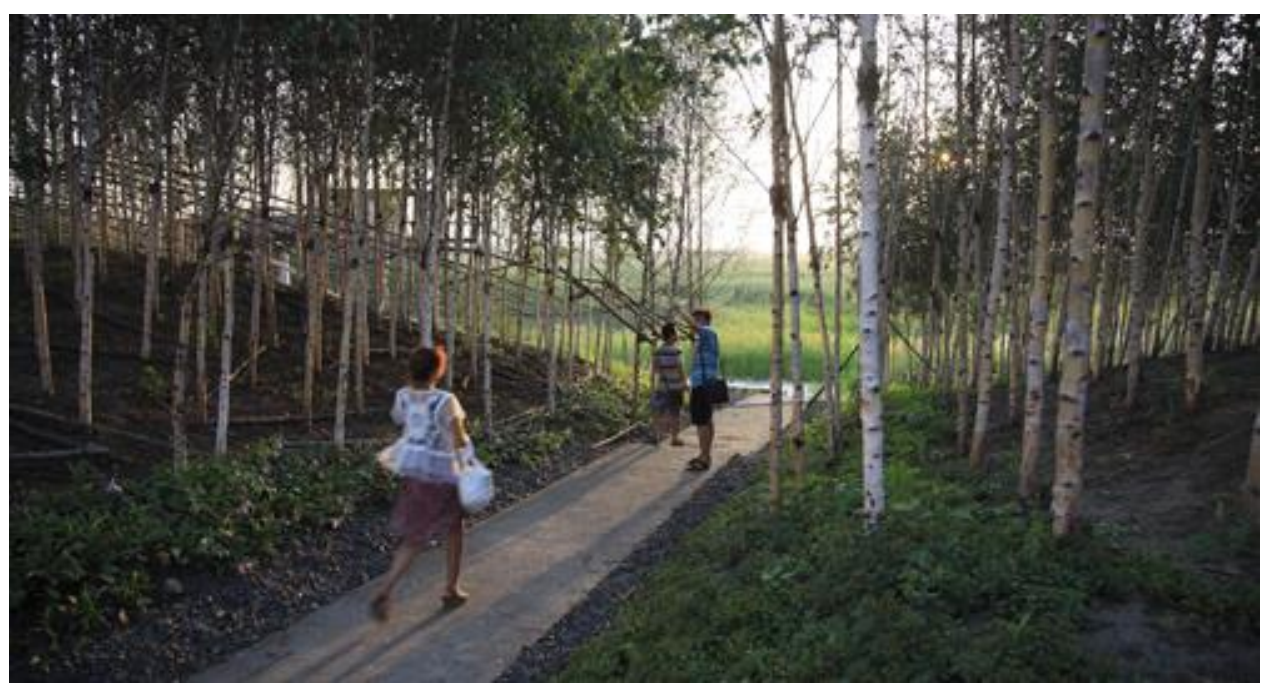

Figure 31. Aggressive - Growing Trees \& Network of Paths 
Qunli Stormwater Park serves as a green sponge, cleansing and storing urban stormwater, which provide multiple ecosystems services for the new community. The stormwater park collects, filtrates, stores stormwater and infiltrates to the aquifer, while providing new recreational and aesthetic experiences for the city. The design allowed the central part of the wetland to succeed naturally, while the exterior sections were graded and additional site features were added (Figure 30). Native silver birch trees (Betula) were grown on the mounds that create a dense forest setting, while native grasses and sedges were used to populate the wetland spaces and provide erosion control. The site can be experienced along multiple levels. A network of paths is built into the ponds allowing visitors to have a walk - through - forest experience. (Figure 31). Platforms and seats enable people to have close contact with nature. ("A Green Sponge for a Water-Resilient City: Qunli Stormwater ParkHaerbin City, Heilongjiang Province, China," 2012).

The stormwater parks proposed for the Mountain Top Industrial Park, will not only serve a vital role for stormwater management and habitat development, but also create places for people to engage with their natural surroundings.

\subsubsection{TaigaNova Eco-Industrial Park- Fort McMurray, Canada}

The TaigaNova Eco-Industrial Park (EIP) is located 7 km north of Fort McMurray's town center on the east side of Highway 63 (Figure 32). It is the first fully built-out, profitable, greenfield eco-industrial park (EIP) in North America ("Build where Industry Thrives," 2011). The site development includes energy efficient buildings and infrastructure (solar powered lighting), and encourages businesses to function as a community. The site is home to the first LEED Gold-rated industrial building in Alberta.

TaigaNova has been recognized internationally as a leading edge development in terms of sustainability. The park uses green infrastructure and innovative sustainable design approaches resulting in a higher quality industrial development. Pedestrian connectivity allows people to easily walk or bicycle between businesses and to amenity areas, while alternative stormwater management including a storm pond is designed as both an amenity and habitat. A new hybrid road cross section allows for alternative stormwater management. The landscape design is 
consistent with community placemaking, ensuring that the industrial park is an attractive gateway (Figure 33).

The businesses and green infrastructure approaches proposed for the Mountain Top Industrial Park will be able to provide local jobs, create revenue for the adjacent communities and create places incorporating natural features.

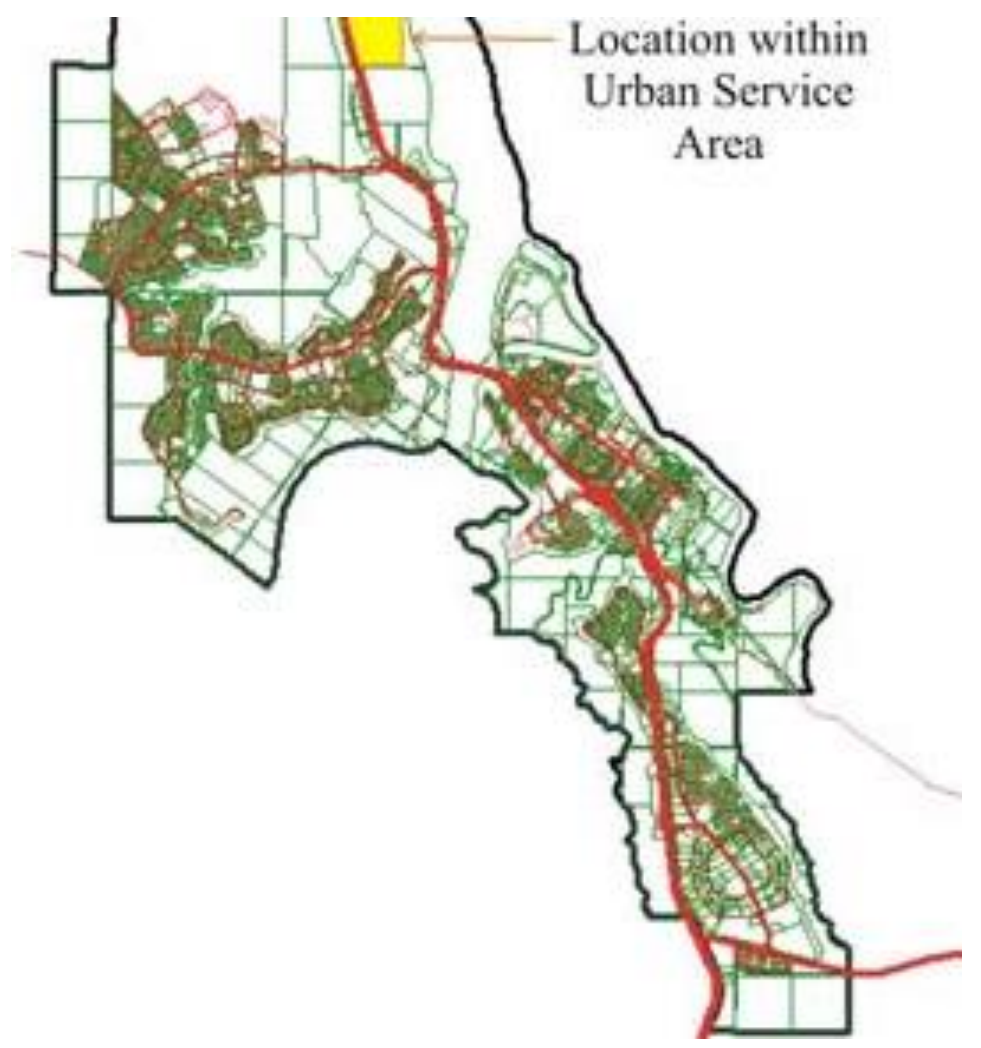

Figure 32. Relation to Fort McMurray town center \& Hwy 63N

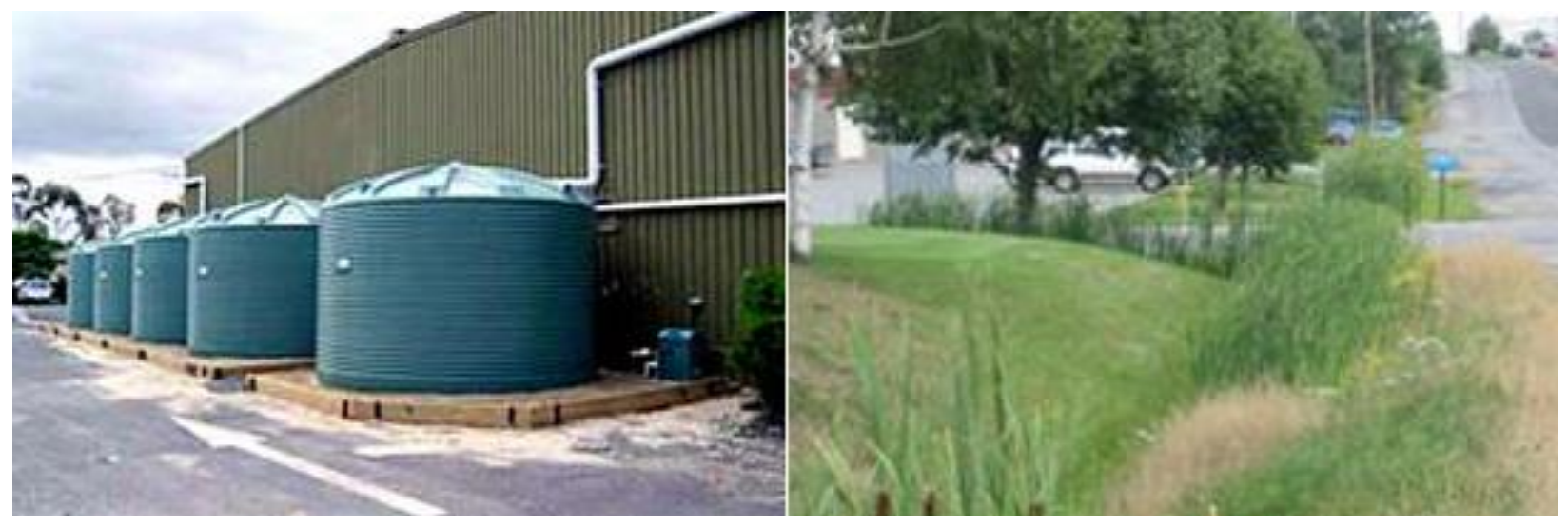

Figure 33. Energy efficient buildings \& infrastructure 


\subsubsection{Renewable Energy Education Park- Pushpa Gujral Science City, India}

Renewable Energy Education Park (REEP) is set up to create awareness of renewable energy sources, and educate students and the public regarding applications of various renewable energy sources and energy conservation measures. Solar Center and Hydel Power Center is an area installed in the park, where various turbine models are displayed to explain their structure and working principles (Figure 34). Some unique civil engineering and landscape design scenarios are integrated with a solar power plant and wind mill in the park area to educate students and the public. The center is comprised of indoor exhibits and outdoor attractions related to renewable energy, which are interactive and educational, such as a solar restaurant, a power generating drum, a battery operated bicycle and a solar car. A solar water heating system is installed to generate hot water in the restaurant. Different models of solar cookers are installed as working models and solar cooked food is served in the restaurant ("Welcome to Pushpa Gujral Science City," 2012).
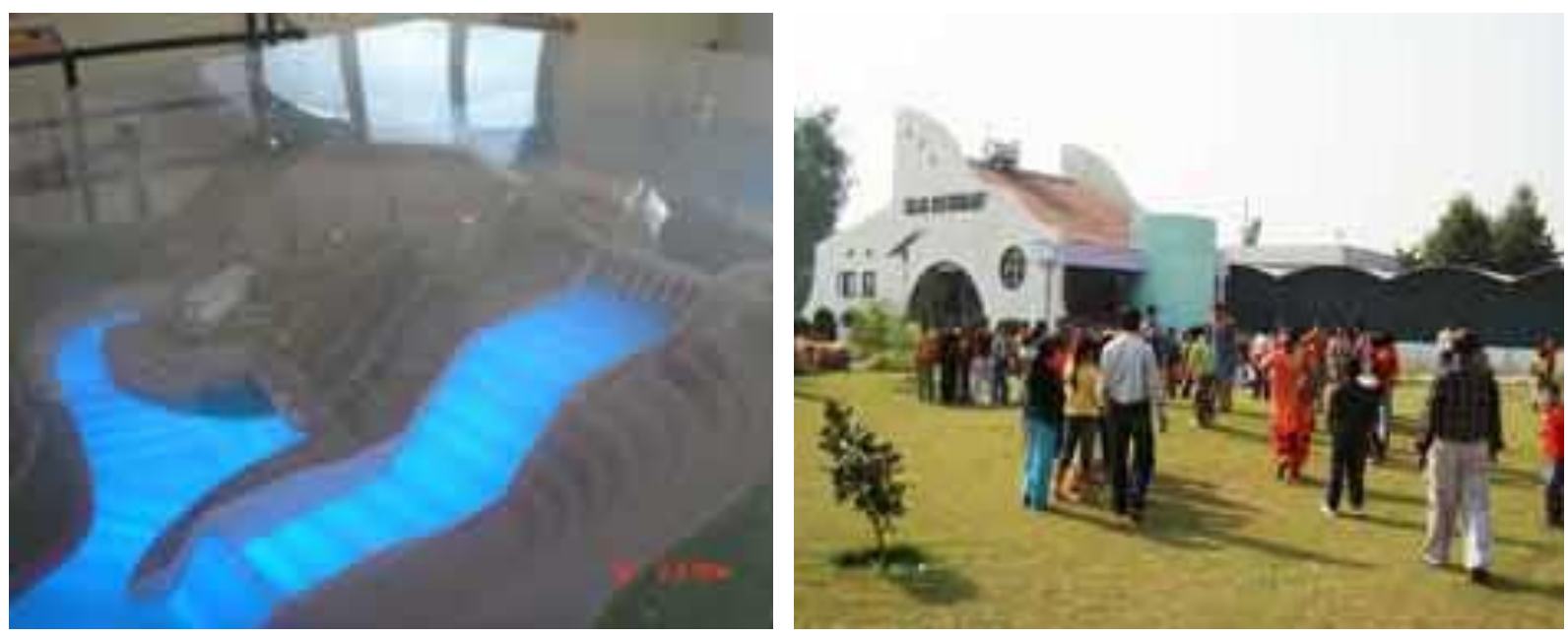

Figure 34. Hydel Power Center \& Solar Restaurant

The Renewable Energy Education Park proposed for the Mountain Top Industrial Park will not only provide a source of reliable, locally-produced clean energy, but it may also contribute to eco-tourism and serve as an educational resource to local schools, universities and business groups. 


\subsection{Functional Diagrams}

Beginning the conceptual design process (Figure 35) involved four steps including analysis, land use, circulation $\&$ access, and outdoor space detailed design to achieve goal.

Step 1 shows the summary from the inventory and analysis. The yellow circle is the development area for Mountain Top Industrial Park, which is around 50 acres in the eastern portion of property. The western portion of the property consists of slopes ranging from $8 \%$ to $20 \%$, which is not suitable for redevelopment. It will be managed in its existing condition, as a forest. The blue color shows the biomass area. Biomass can be planted on the former surface coal mine (Laurel) and under transmission lines for site redevelopment.

Step 2 focuses on the development area. The industrial area is designed adjacent to the CSX railroad, while the commercial area is closer to Corridor $\mathrm{H}$ to take advantage of existing and future transportation. The natural-based education program is designed close to forest, which works as a stormwater collection area because of good soil permeability.

Step 3 depicts general circulation and access patterns. Two types of entrances and circulation are designed for different types of visitors. The primary entrance and circulation systems serve for commercial area and nature-based education programs area. The secondary entrance and circulation systems serve the industrial area. The rail spur in the industrial area is designed to collect biomass from the CSX railroad for the biomass processing center.

Step 4 follows the design principles of symmetry, emphasis, and axial design. The new energy museum, café and conference hall are located at the center of the site development; and the surface mine museum is located adjacent to the former surface coal mine, which is also the beginning of the walking tour of the surface mine. All the elements are connected by pedestrian circulation systems and the four axes within the form of the linear museums. The four linear museums exhibit different themes of new energy. The axes lead to lodging, the welcome center, and the wind and solar energy exhibit. The axes leading to the forest and industrial area exhibit biomass energy production. 


\section{Step 1:}

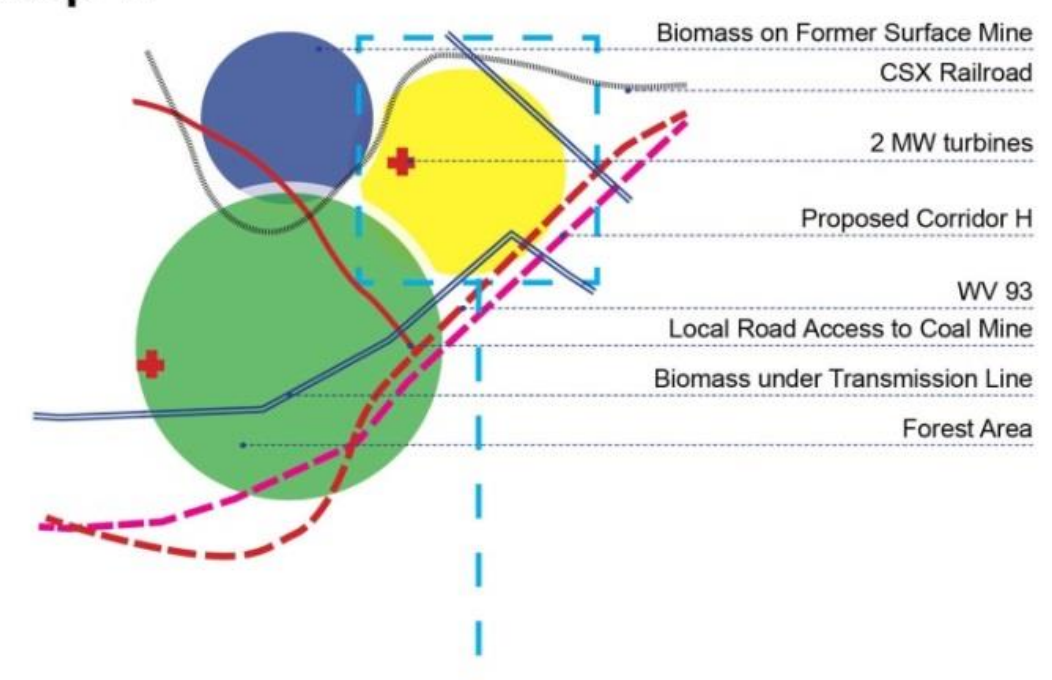

\section{Step 2:}

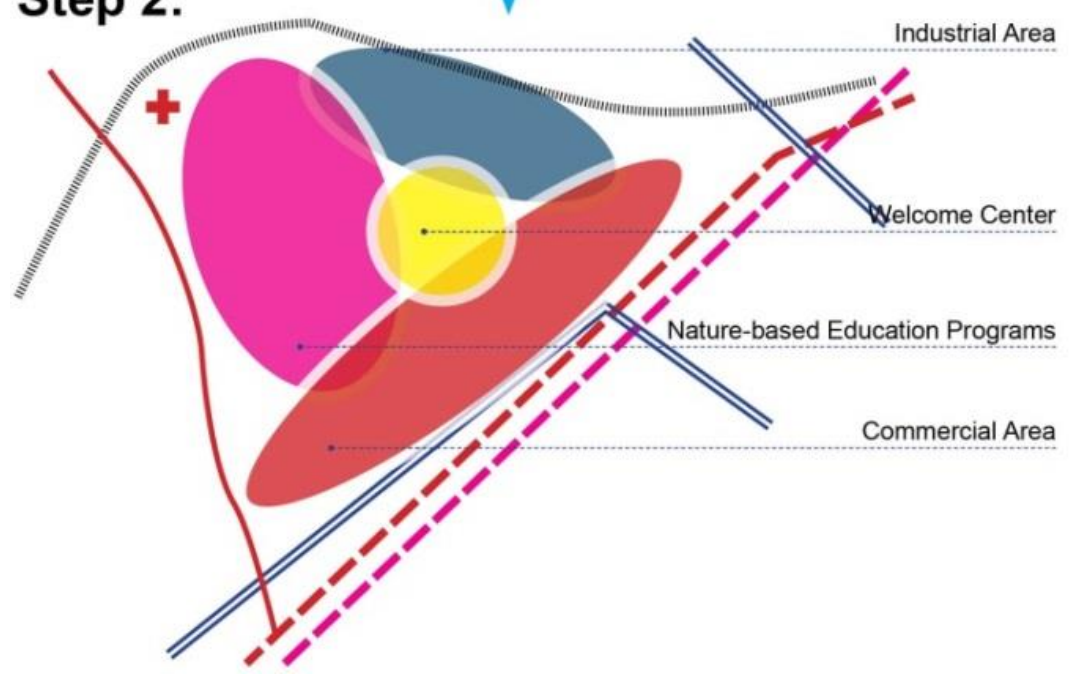

Step 3:

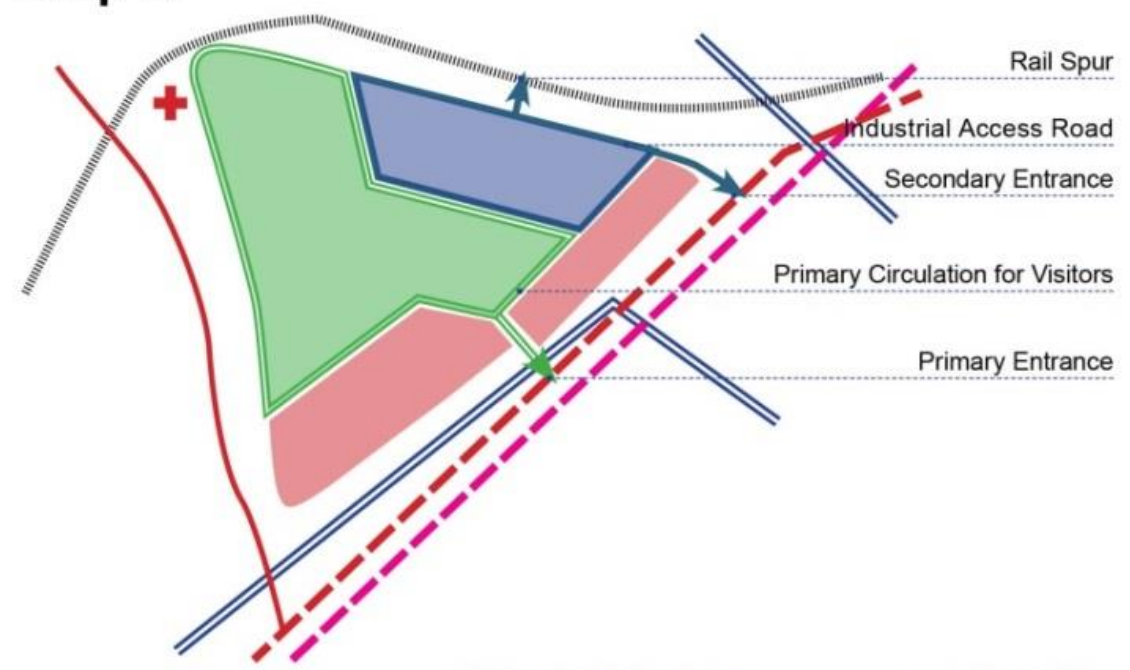

\section{Step 4:}

SYMMETRICALLY
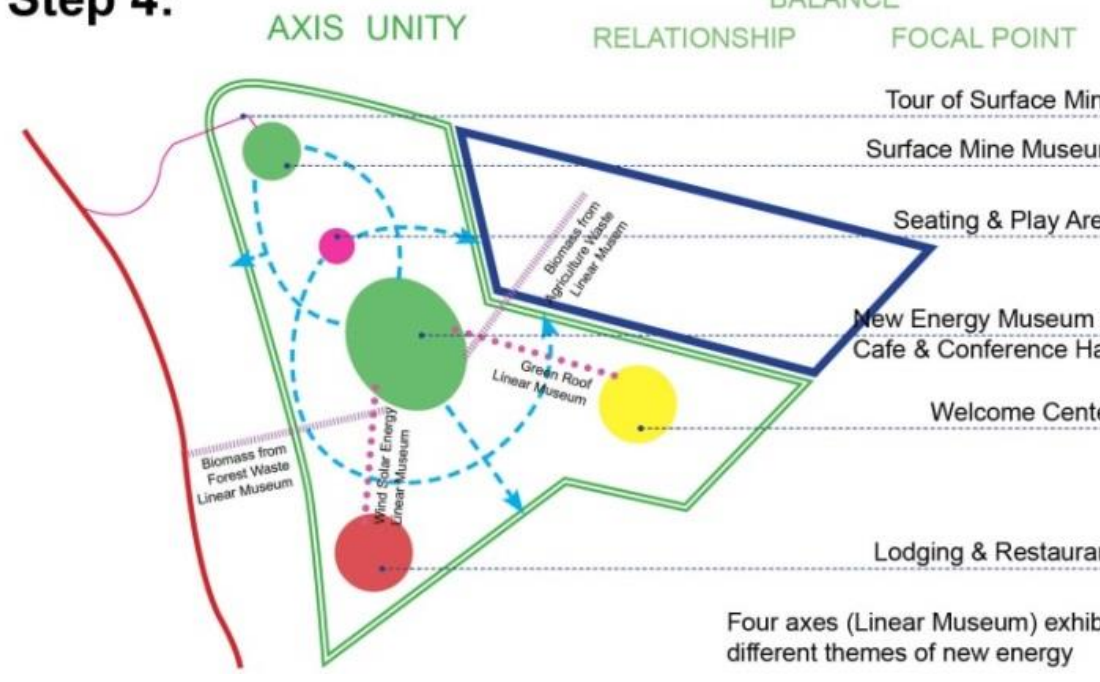

Tour of Surface Mine Surface Mine Museum

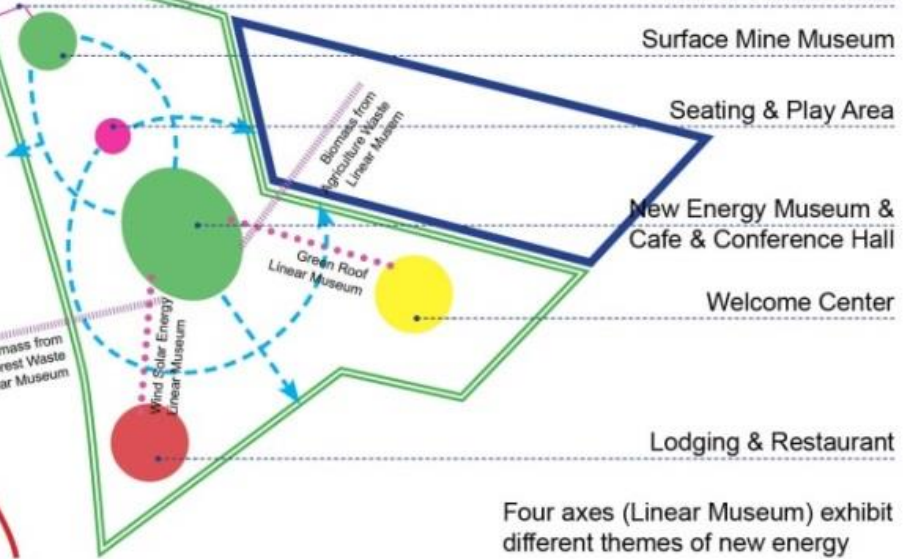
different themes of new energy

Figure 35. Design Process 


\subsection{Concept}

The form of the design responds to the orderly frames of development, interrupted by the chaos of biological patterns, which is recognized through natural processes such as stormwater collection organically weaving through the site. The open space applied the concept of minimalism in the landscape (Levy, 1997), which suggests a conceptual order and the reality of changing natural systems with geometry, narrative, rhythm, gesture, and other devices that can imbue space with a sense of unique place that lives in memory. Rather than focusing on design and functional issues as mutually exclusive, minimalism leads to examination of the abstract and the essential, qualities of both classicist and modernist design (Levy, 1997). Stormwater collection and open space are linked through pedestrian greenways creating connections that bond people to place. The nature-based education programs area connect the welcome center, commercial area and industrial area and serve as spaces for education purposes and reflection of local landscape patterns. The development is focused on formal and decorative issues on the one hand and sociological and functional issues on the other (Figure 36).

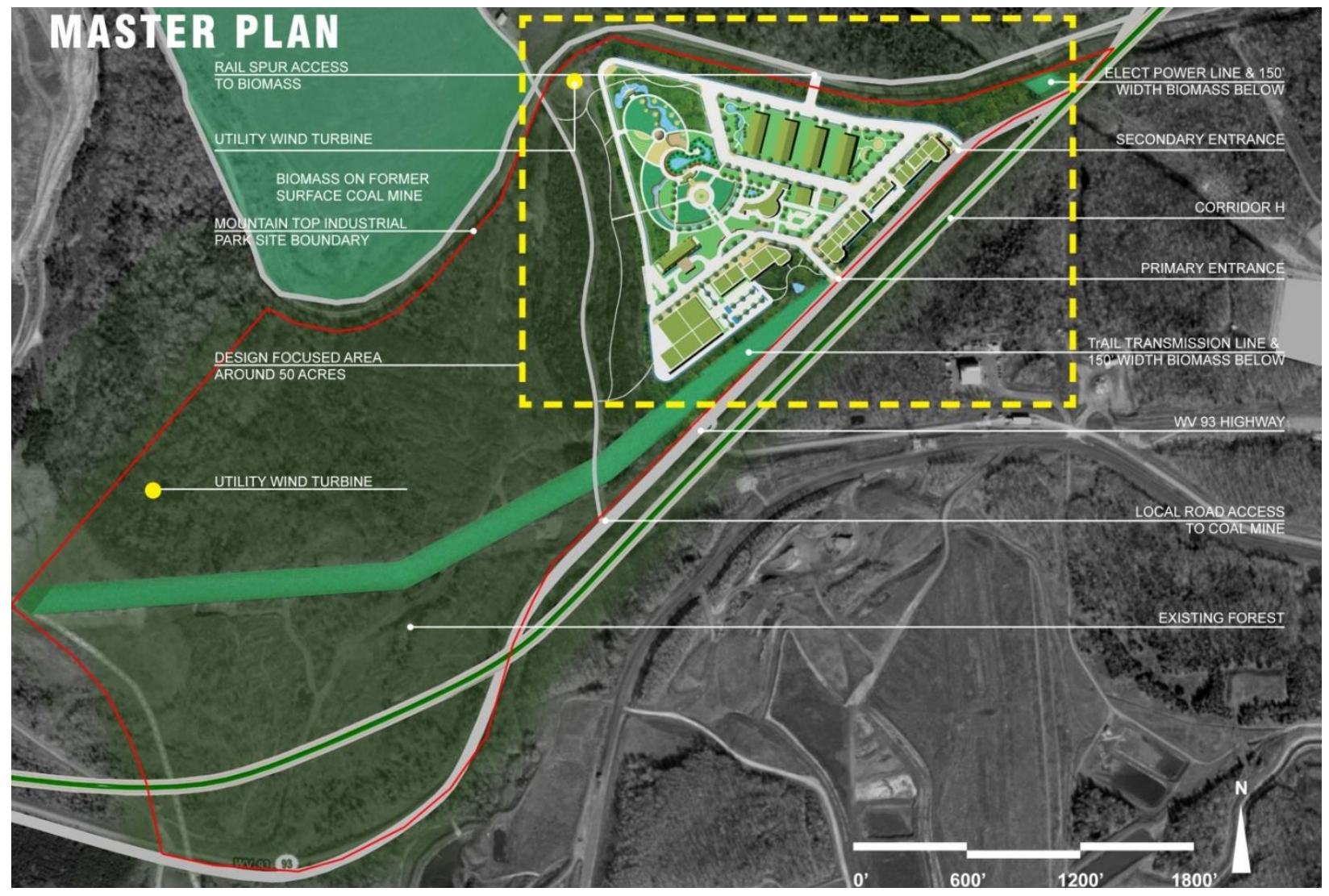

Figure 36. Mountain Top Industrial Park Master Plan 


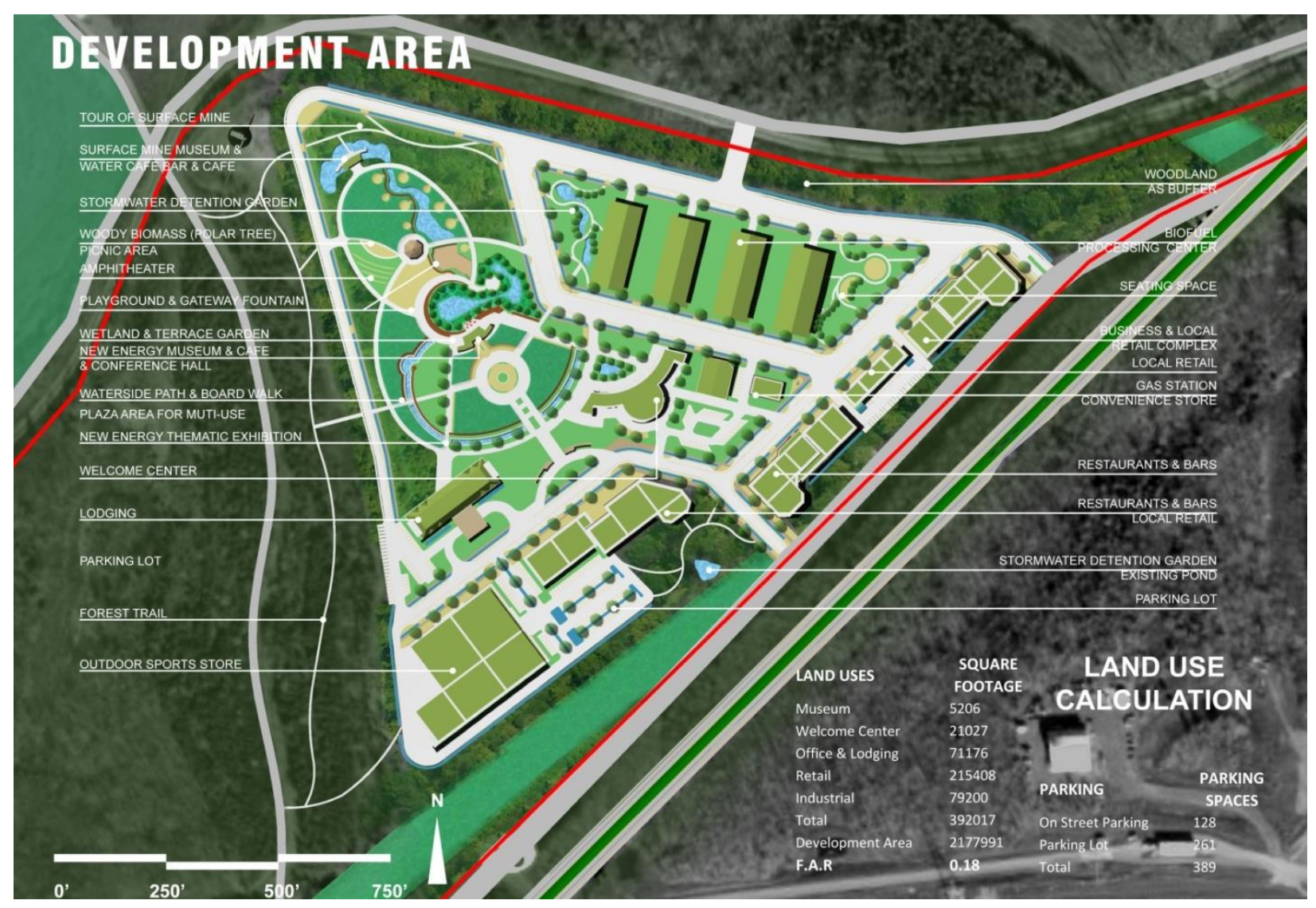

Figure 38. Mountain Top Industrial Park Master Plan Development Area
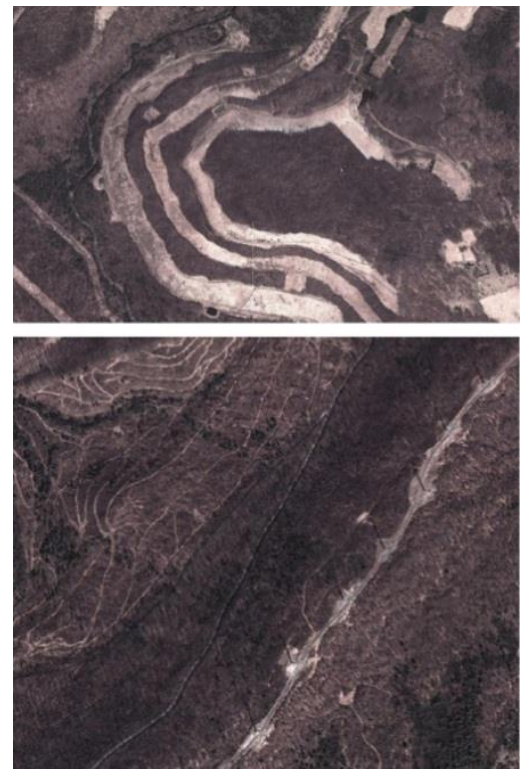

Figure 37. Local Landscape Patterns
This area of the site is developed as mixed-use along proposed Corridor $\mathrm{H}$, which contains the commercial, industrial, recreational and educational areas (Figure 38). Stormwater weaves through the site with several stormwater collection areas.

The site generally took the form of classical land form axes, staircases, and local landscape patterns - terraces and series of open space to imbue space with a sense of unique place (Figure 37). The picnic areas in series make use of Ned Power Wind farm's landscape pattern. The Garden terrace in front of the new energy museum makes use of surface coal mine patterns. 


\subsection{Perspective}

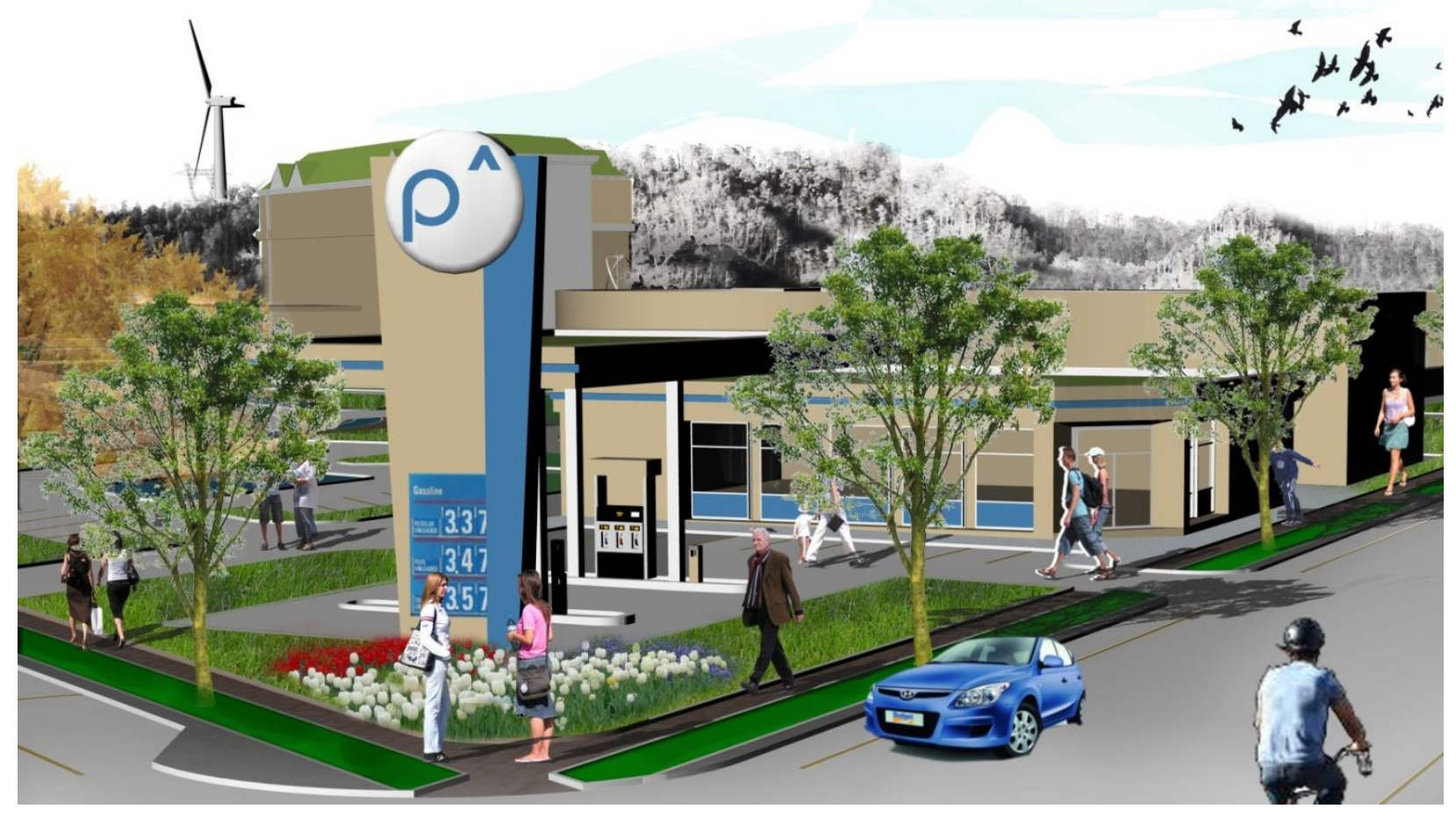

Figure 39. Gas Station Serves for Industrial \& Commercial Areas

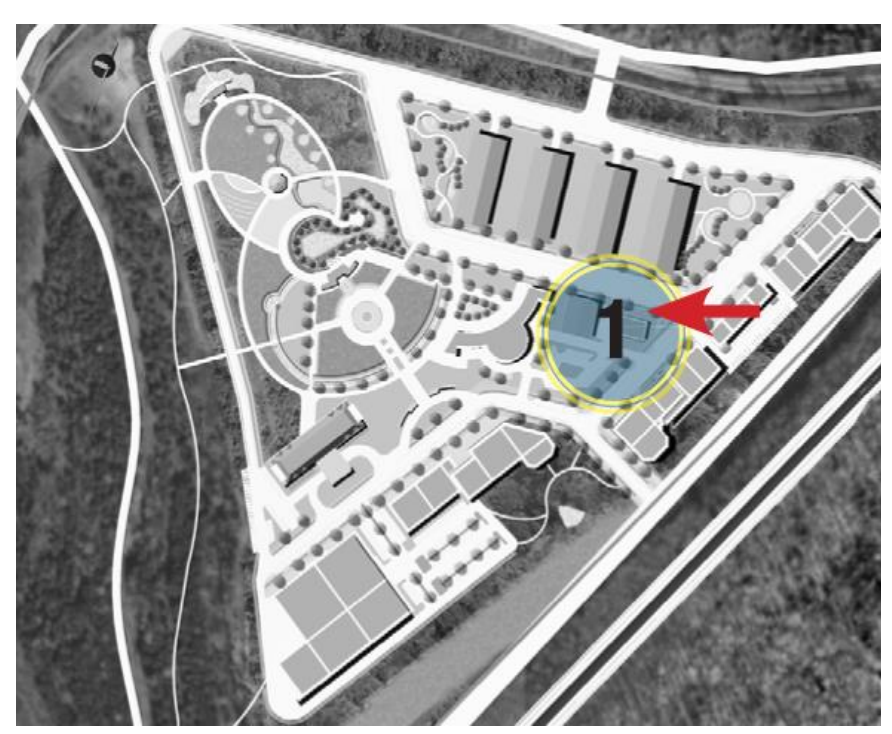

Figure 40. Gas Station Location Map
The gas station in the corner of site will separate potential traffic conflicts between the industrial and recreational areas (Figure 39). Bioretention planters are designed to collect and absorb stormwater runoff from nearby paved surfaces like streets and sidewalks. Pedestrian connectivity allows people to easily walk or bicycle in the park. The convenience store and gas station have long shopping hours to meet the needs of visitors. 


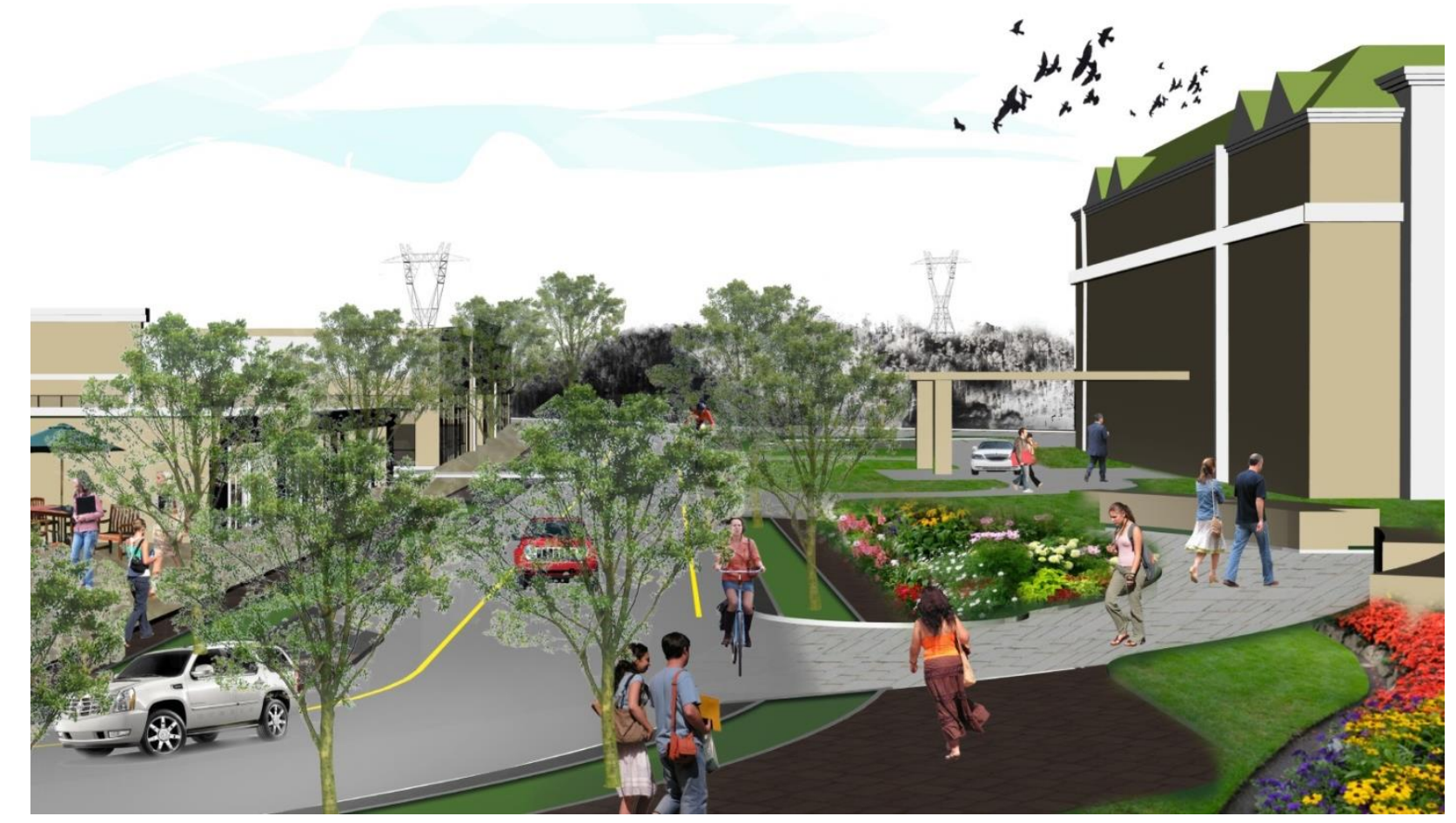

Figure 41. Local Retail \& Lodging

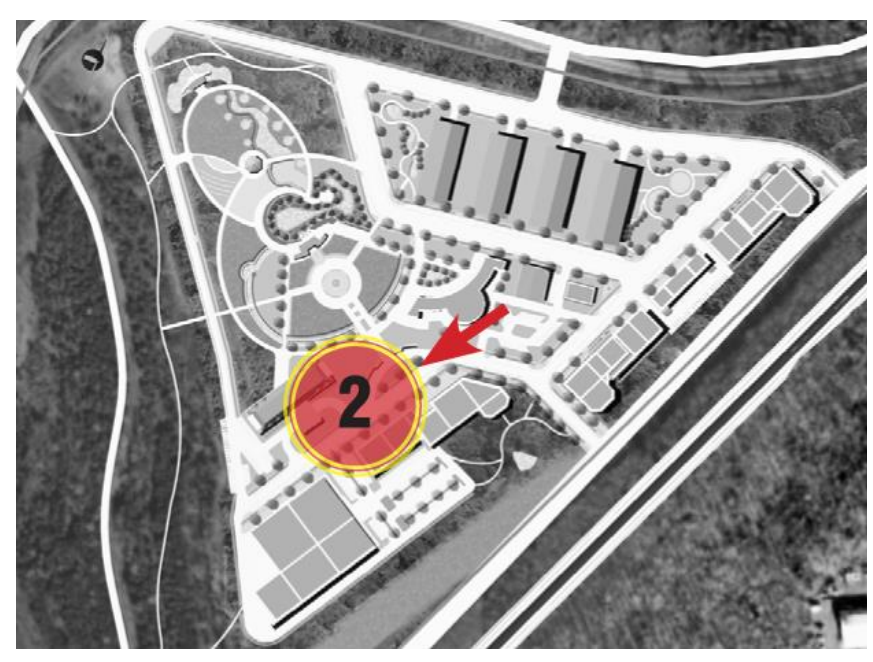

Figure 42. Local Retail \& Lodging Location Map
In order to bring more business to this region, commercial, retail and lodging facilities are proposed along Corridor $\mathrm{H}$. Pedestrian connectivity allows people to easily walk or bicycle between businesses and other areas. This area includes on street parking serving the commercial, retail and business uses, and recreation area. Bioretention planters are designed along the street and achieve a functional transition from road to outdoor dining space (Figure 41). 


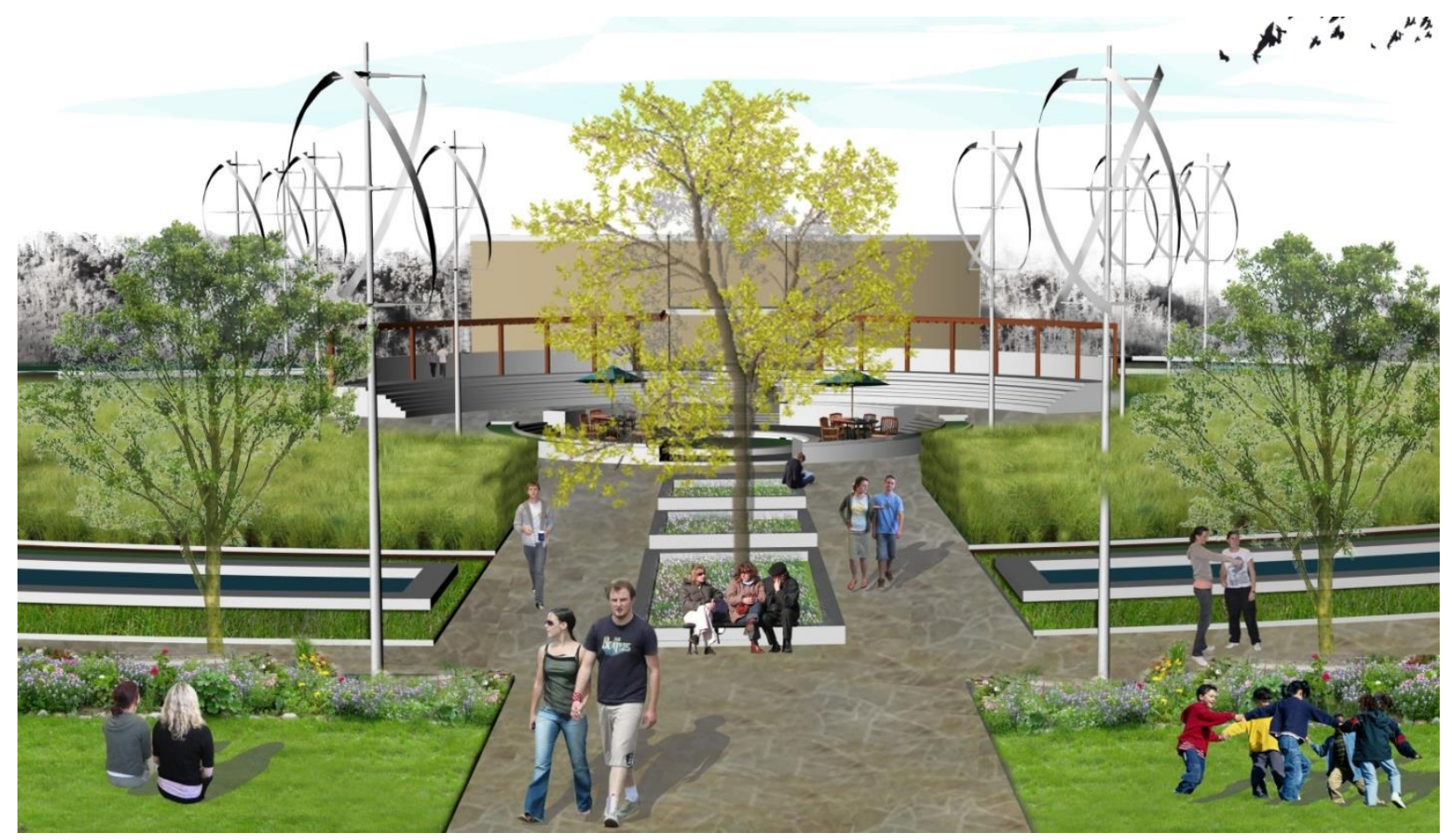

Figure 43. New Energy Museum

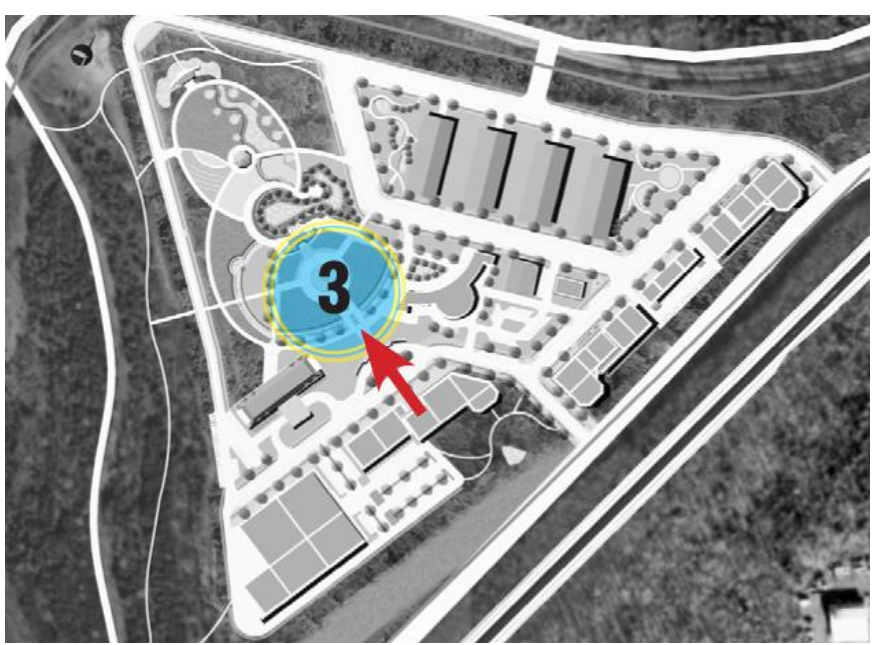

Figure 44. New Energy Museum Location Map

The green spaces not only serve as a stormwater movement and filtration areas, but will become a greenway for pedestrian movement and gathering. It is an important element in providing healthy spaces for visitors, while also providing a space to connect fragmented ecology.

Perennial biomass plantings and community scale wind turbines are designed in front of the energy museum to reinforce the project theme of energy production. The garden terrace in front of the new energy museum makes use of surface coal mine patterns to reflect the local environment. The Wood Corridors in front of building are outdoor linear museums, which also function as seating and relaxation areas (Figure 43). 


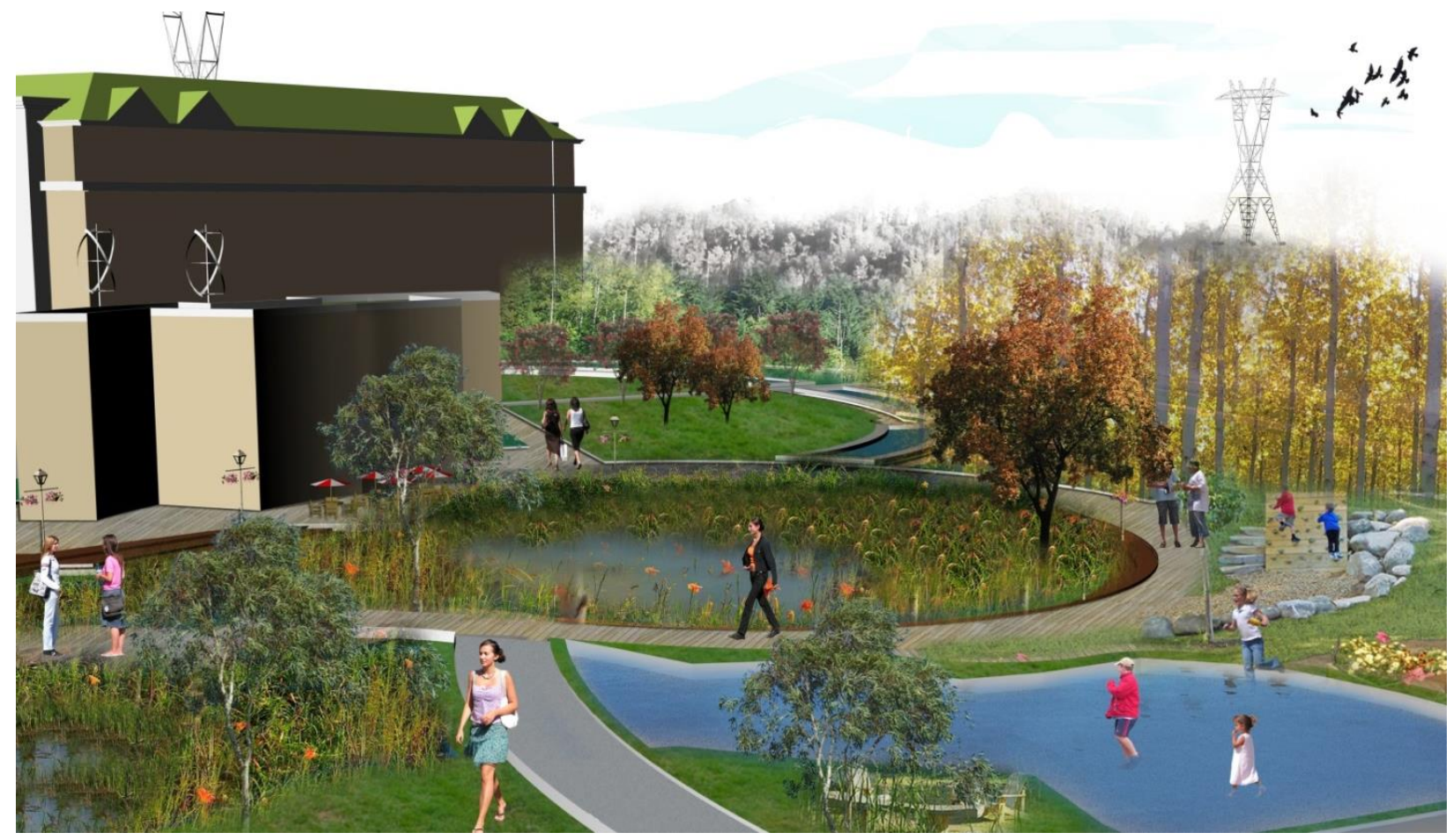

Figure 45. Wetland \& Natural Playground

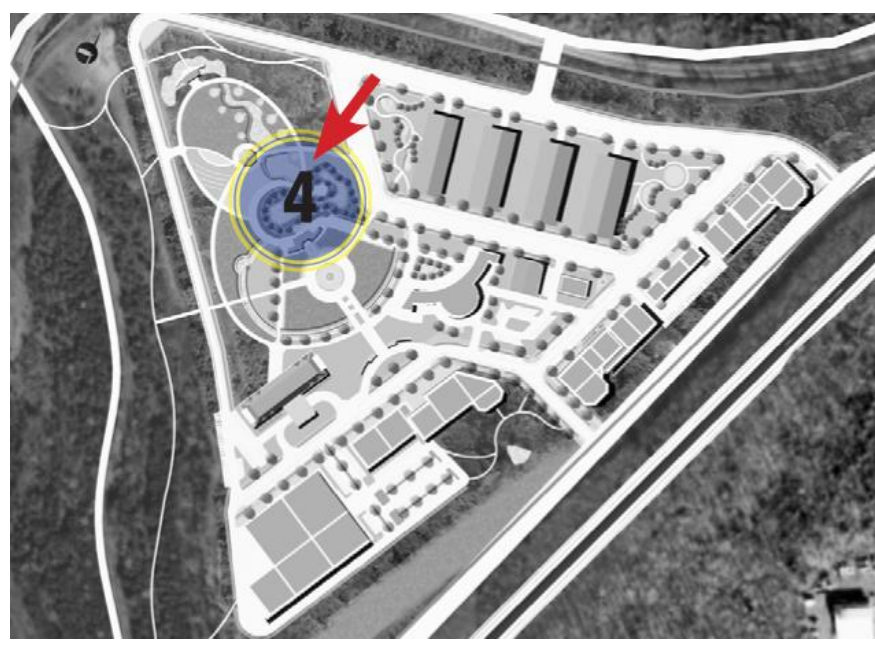

Figure 46. Wetland \& Natural Playground Location Map
A natural playground, gateway fountain, outdoor café and wetland are designed to enhance the new development of nature-based tourism (Figure 45). The wetland will build ecological function into the landscape, while manage the site's stormwater and provide passive recreational and social space. The wetland consists of temporary ponds (Galatowitsch \& Valk, 1994), which have a periphery of wet prairie and a central area dominated by a diverse planting of sedges. These spaces are important because they provide a mutually supportive habitat, consider people, wildlife and plant communities. 


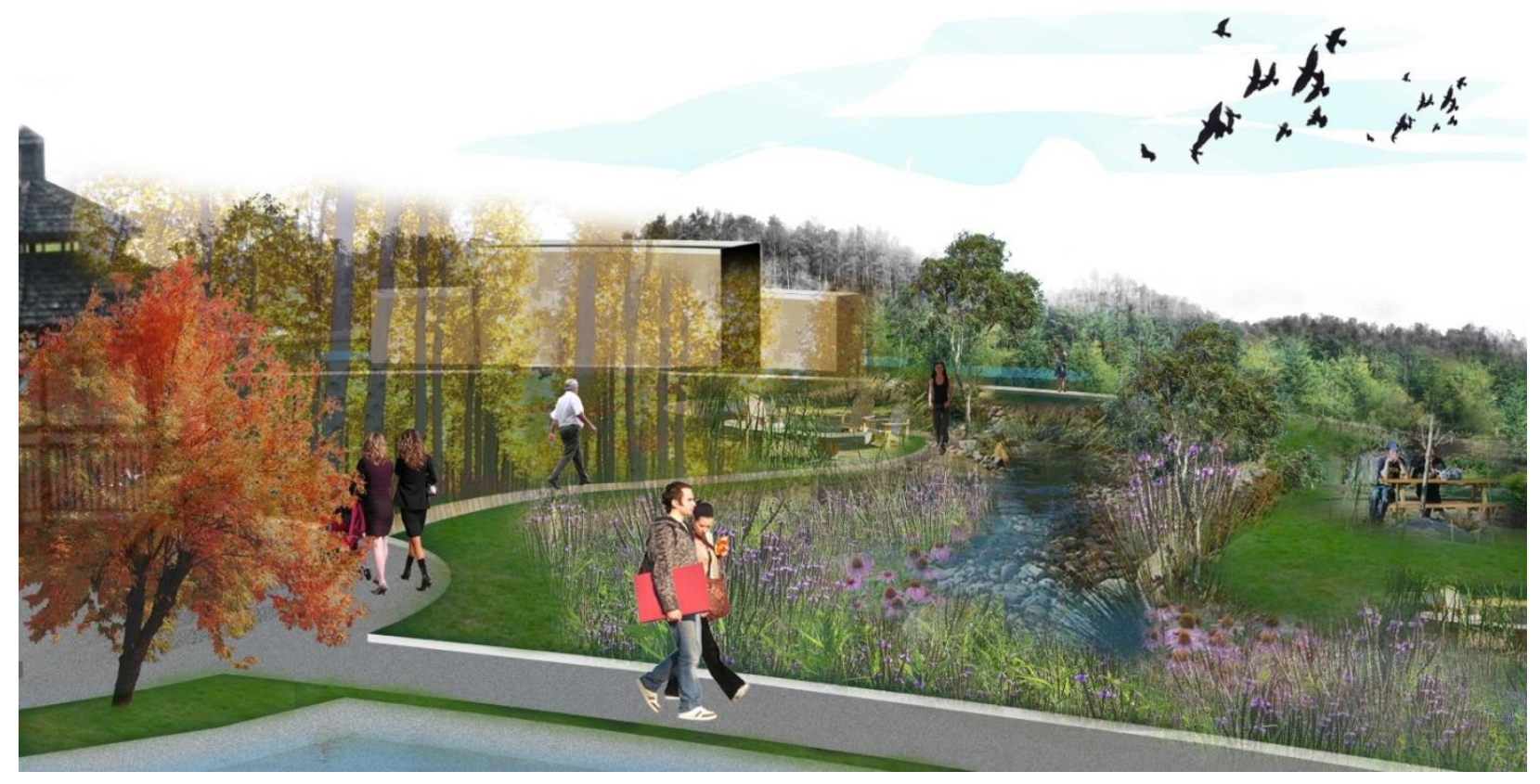

Figure 47. Bioretention \& Surface Mine Museum

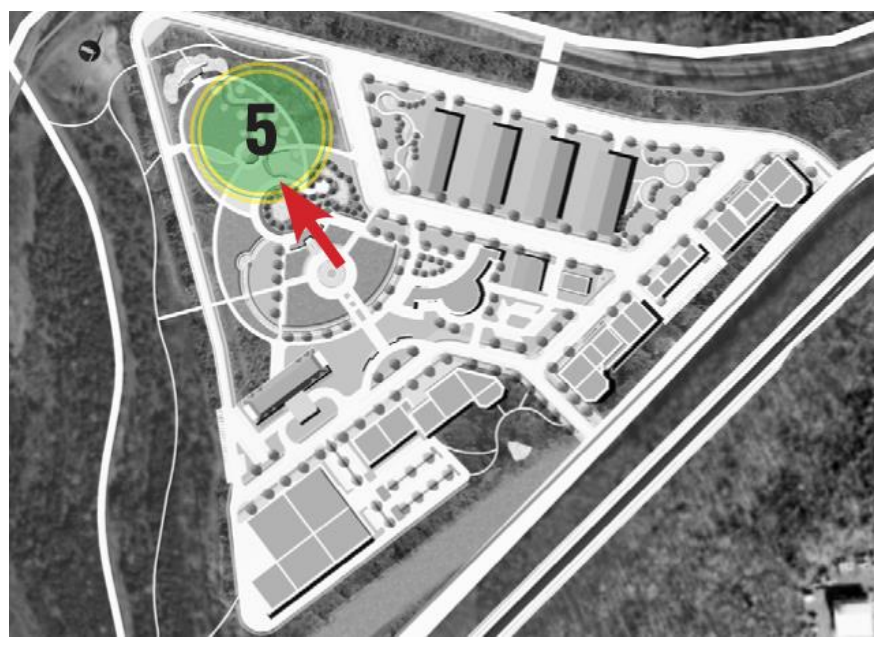

Figure 48. Bioretention \& Surface Mine Museum Location Map

The pavilion, woody biomass, surface mine museum, and bioretention picnic areas are linked through pedestrian greenways creating connections that bond people to place (Figure 47). The bioretention system weaves through the site with native plantings to cleanse and infiltrate stormwater. The boardwalk starts from the new energy museum and leads to the surface mine museum following the bioretention system, which inspires people to experience nature while improving their biofuels literacy. The series of picnic areas create spaces to engage people in nature and social interaction with other visitors, which makes use of Ned Power Wind farm's landscape pattern. 


\section{Chapter 4. Stormwater Management}

\subsection{Chesapeake Stormwater Design Criteria}

From inventory and analysis, stormwater management will be a concern in the development area because of the relatively flat topography. In order to enhance hydrologic function in the landscape, bioretention systems will be employed. The primary component of a bioretention practice is the filter bed, which has a mixture of sand, soil, and organic material as the filtering media with a surface mulch layer. During storms, runoff temporarily ponds 6 to 12 inches above the mulch layer and then rapidly filters through the bed. These systems infiltrate, evapo-transpire or reuse stormwater runoff, while improving water quality. The systems also improve and stabilize the soil and create wildlife habitat by improving biodiversity. The overall stormwater functions of the bioretention system are summarized in Table 4 ("Virginia DCR Stormwater Design Speification No. 9 Bioretention," 2011).

Table 4. Summary of Stormwater Functions Provided by Bioretention Basins

\begin{tabular}{|c|c|c|}
\hline Stormwater Function & Level 1 Design & Level 2 Design \\
\hline Annual Runoff Volume Reduction (RR) & $40 \%$ & $80 \%$ \\
\hline $\begin{array}{l}\text { Total Phosphorus (TP) EMC Reduction1 } \\
\text { by BMP Treatment Process }\end{array}$ & $25 \%$ & $50 \%$ \\
\hline $\begin{array}{l}\text { Total Phosphorus (TP) Mass Load } \\
\text { Removal }\end{array}$ & $55 \%$ & $90 \%$ \\
\hline $\begin{array}{l}\text { Total Nitrogen (TN) EMC Reduction1 by } \\
\text { BMP Treatment Process }\end{array}$ & $40 \%$ & $60 \%$ \\
\hline $\begin{array}{l}\text { Total Nitrogen (TN) Mass Load } \\
\text { Removal }\end{array}$ & $64 \%$ & $90 \%$ \\
\hline
\end{tabular}

Level 1 Design is a baseline design. Level 2 Design can achieve a greater degree of stormwater runoff pollutant reduction. For the design at Mountain Top Industrial Park the Level 2 Design is applied. The design criteria for Level 2 Design include:

- Individual bioretention areas less than 2 acres in size

- Water storage depth: 6"

- Filter media depth (sand, soil \& organic): 36"

- Underdrain 6" schedule 40 pvc 


\subsection{Sizing of Bioretention}

Sizing of the surface area (SA) for bioretention practices is based on the computed Treatment Volume ( $\mathrm{Tv}$ ) of the contributing drainage area and the storage provided in the facility. The required surface area is computed as the Treatment Volume divided by the equivalent storage depth. The equivalent storage depth is computed as the depth of media, gravel, or surface ponding multiplied by the accepted void ratio ("Virginia DCR Stormwater Design Speification No. 9 Bioretention," 2011).

The accepted Void Ratios (Vr) are (see Figure 49 below):

- Bioretention Soil Media $\mathrm{Vr}=0.25$

- Gravel $\mathrm{Vr}=0.40$

- Surface Storage $\mathrm{Vr}=1.0$

The equivalent storage depth for Level 2 with a 6-inch surface ponding depth and a 12inch gravel layer is computed as Equation 1.

$$
(3 \mathrm{ft} . \times 0.25)+(1 \mathrm{ft} . \times 0.40)+(0.5 \times 1.0)=1.65 \mathrm{ft}
$$

Therefore, the Level 2 Bioretention Surface Area is computed as Equation 2.

$$
\mathrm{SA}=[(1.25 \mathrm{U} \mathrm{Tv})-\text { the volume reduced by an upstream BMP] / } 1.65 \mathrm{ft} . \quad \text { (Equation 2) }
$$

where:

$$
\begin{aligned}
& S A=\text { Minimum surface area of bioretention filter }(\text { sq. } \mathrm{ft} .) \\
& T v=\text { Treatment Volume }(\mathrm{cu} . \mathrm{ft} .)=[(1.0 \mathrm{in} .)(\mathrm{Rv})(\mathrm{A}) / 12] \\
& \mathrm{Rv}=\text { the composite runoff coefficient from the RR Method }(\text { Table 5) }
\end{aligned}
$$


Table 5. Stormwater Runoff Coefficient Standard

\begin{tabular}{|c|c|c|c|}
\hline \multicolumn{4}{|c|}{ RUNOFF COEFFICIENTS } \\
\hline Land Use & \multicolumn{3}{|c|}{ "C" Values } \\
\hline \multicolumn{4}{|l|}{ Urban Surfaces } \\
\hline Roofs & \multicolumn{3}{|c|}{$0.80-0.95$} \\
\hline Asphalt \& Concrete Pavement & \multicolumn{3}{|c|}{$0.75-0.95$} \\
\hline Gravel & \multicolumn{3}{|c|}{$0.35-0.70$} \\
\hline Rural Subdivisions & Sandy & Silt / Loam & Clay \\
\hline \multicolumn{4}{|l|}{ Woodland } \\
\hline Flat (0 - 5\% slope) & 0.10 & 0.30 & 0.40 \\
\hline Rolling (5 - 10\% slope) & 0.25 & 0.35 & 0.50 \\
\hline Hilly (10 - 30\% slope) & 0.30 & 0.50 & 0.60 \\
\hline \multicolumn{4}{|l|}{ Pasture and Lawns } \\
\hline Flat (0 - 5\% slope) & 0.10 & 0.30 & 0.40 \\
\hline Rolling (5 - 10\% slope) & 0.16 & 0.36 & 0.55 \\
\hline Hilly (10 - 30\% slope) & 0.22 & 0.42 & 0.60 \\
\hline
\end{tabular}

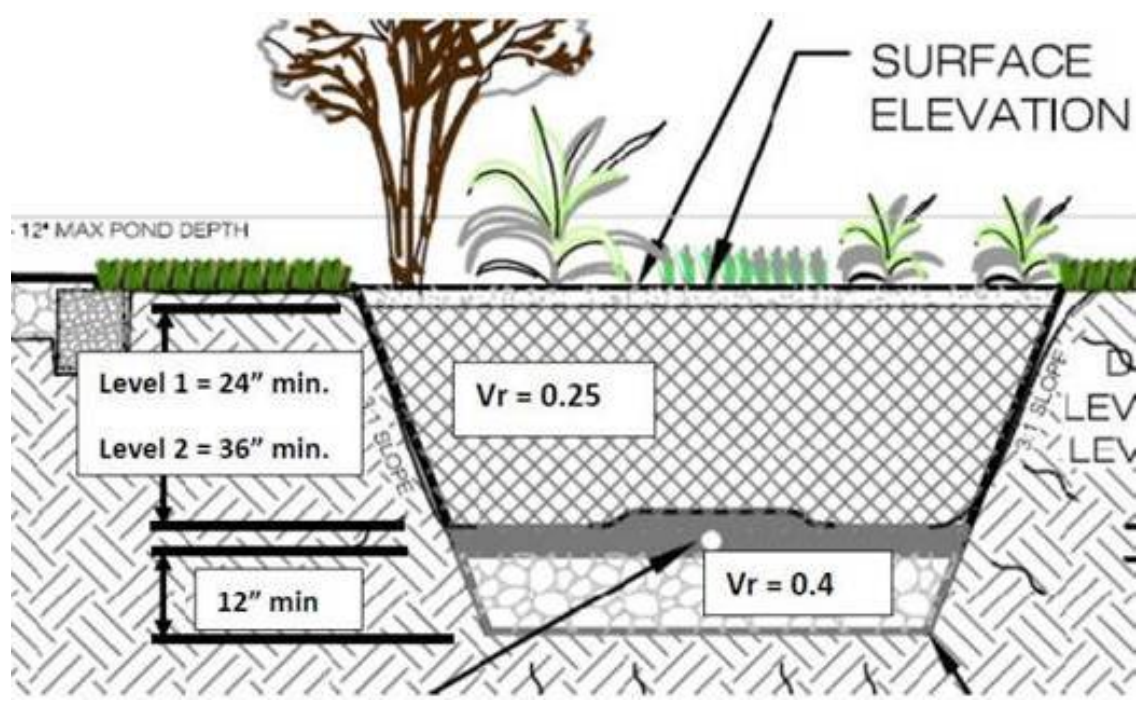

Figure 49. Typical Bioretention Section with Void Ratios for Volume Computations 


\subsubsection{Bioretention Surface Area in Mountain Top Industrial Park}

Bioretention is best applied in Mountain Top Industrial Park because the grade of contributing slopes is greater than $1 \%$ and less than $8 \%$. Soil conditions do not constrain the use of bioretention. However, they will impact the size of bioretention elements. The site is divided into thirty-one drainage sections, because bioretention drainage areas should less than two acres (Figure 50). From equations above, the minimum size of bioretention elements for each section are summarized in Table 6.

Through analysis of topography and soil type, bioretention surface areas are designed as an integral component of the overall conceptual design (Table 6). Bioretention planters are located along the street and at parking lots to collect and absorb stormwater runoff from nearby paved surfaces like streets and sidewalks. The irregular outlines of bioretention elements not only collect and absorb stormwater and also blend naturally into the environment (Figure 50).

Table 6. Minimum Sizing of Bioretention \& Design Bioretention Surface Area

\begin{tabular}{|c|c|c|c|c|c|}
\hline Section & $\begin{array}{c}\text { Sizing of the } \\
\text { Surface Area (Sq. Ft) }\end{array}$ & $\begin{array}{l}\text { Design Bioretention } \\
\text { Surface Area (Sq. Ft) }\end{array}$ & Section & $\begin{array}{c}\text { Sizing of the } \\
\text { Surface Area (Sq. Ft) }\end{array}$ & $\begin{array}{l}\text { Design Bioretention } \\
\text { Surface Area (Sq. Ft) }\end{array}$ \\
\hline 1 & 507 & 1263 & 16 & 829 & 865 \\
\hline 2 & 1702 & 2376 & 17 & 2976 & 6394 \\
\hline 3 & 1719 & 1841 & 18 & 2441 & 2503 \\
\hline 4 & 1905 & 4037 & 19 & 2618 & 4138 \\
\hline 5 & 1252 & 2433 & 20 & 1650 & 1898 \\
\hline 6 & 2525 & 2399 & 21 & 2762 & 2775 \\
\hline 7 & 2864 & 3081 & 22 & 2455 & 3669 \\
\hline 8 & 2425 & 3548 & 23 & 1846 & 4159 \\
\hline 9 & 2378 & 3726 & 24 & 1504 & 1675 \\
\hline 10 & 1898 & 2371 & 25 & 1230 & 2521 \\
\hline 11 & 1023 & 4095 & 26 & 2040 & 2320 \\
\hline 12 & 2140 & 4030 & 27 & 2325 & 22000 (Wetland) \\
\hline 13 & 1778 & 3094 & 28 & 2544 & 4777 \\
\hline 14 & 2686 & 3000 & 29 & 2725 & 5580 \\
\hline \multirow[t]{2}{*}{15} & 1583 & 2206 & 30 & 1629 & 2951 \\
\hline & & & 31 & 1732 & 7300 \\
\hline
\end{tabular}



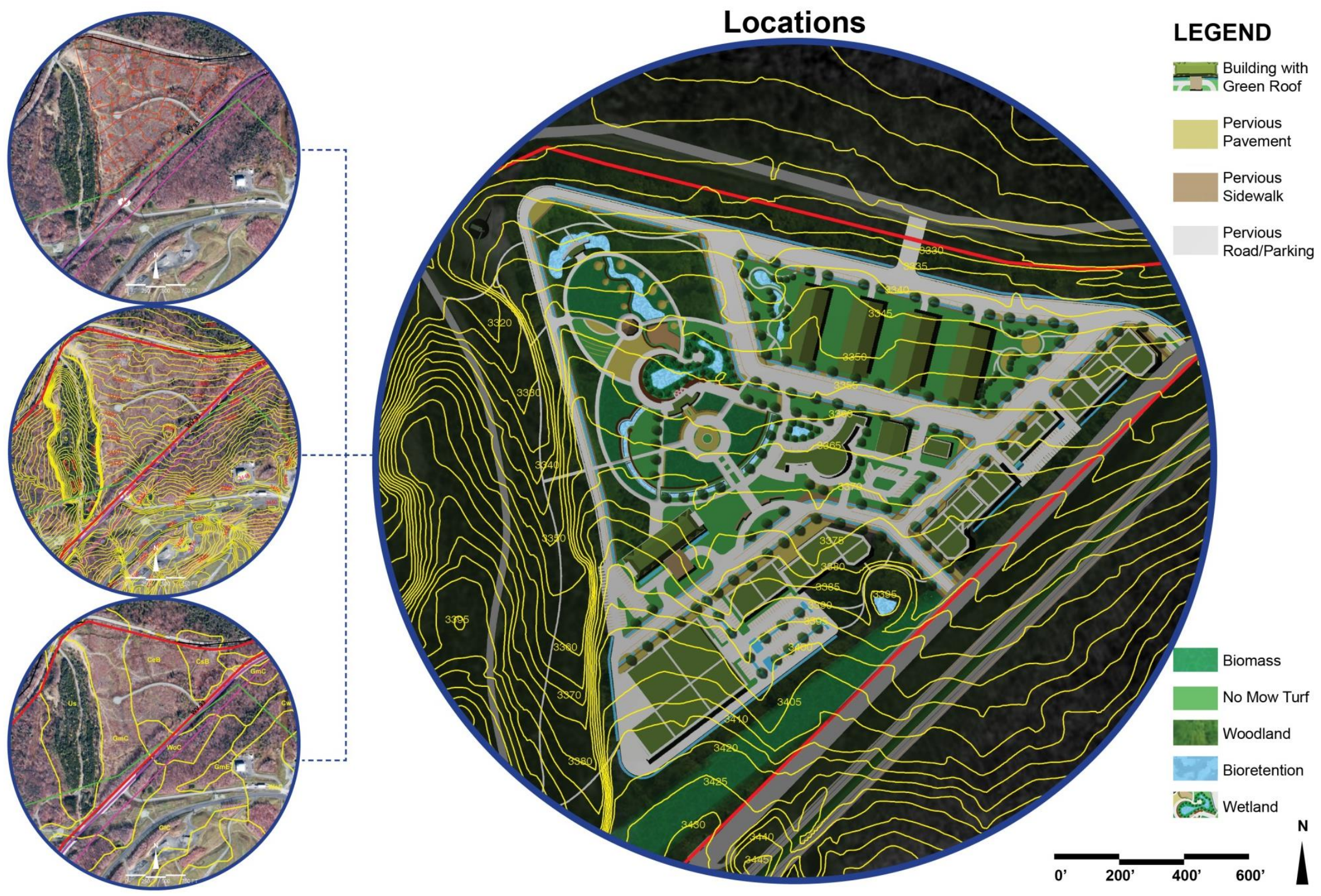

Figure 50. Stormwater Strategies \& Locations in Mountain Top Industrial Park 


\section{Chapter 5. Detailed Design}

\subsection{Plant Selection Principle}

Seven planting design principles are proposed for application in Mountain Top Industrial Park. To provide an integrated approach to the industrial park development, planting design will help to protect and sustain the local environment by decreasing waste, reducing pollutant runoff and soil erosion, improving air and water quality, and protecting wildlife habitat ("River - Friendly Landscping," 2011).

Landscape Locally - Take into Account the Existing Site Characteristics

Consider climate, sun exposure, and soil type and avoid using invasive species

\section{Landscape for Less to the Landfill}

Use on-site plant debris as mulch and compost on-site plant debris

$>$ Nurture the Soil - Promote Beneficial Soil Organisms

Amend the soil with compost before planting and mulch regularly

\section{Conserve Water}

Minimize lawn and grow native plants

\section{$>$ Conserve Energy}

Plant trees to shade homes, paved areas, and air conditioners

\section{$>$ Protect Water \& Air Quality}

Choose pest-resistant plant varieties, create bioretentions and support beneficial insects

\section{$>$ Create \& Protect Wildlife Habitat}

Create diversity by choosing native plants first

A variety of tree, shrub, wildflower, sedge, grass and forb species are chosen to create diversity to create wildlife habitat for the Mountain Top Industrial Park. All of these plants are native and prefer acidic soil, considering climate, sun exposure. They are planted to conserve water and energy by shading buildings, paved areas and air conditioners, and create wildlife habitat by creating diversity (Figure 51). 


\subsection{Biomass Species Plant Palettes}

Fast growing plants such as poplar trees and perennial grasses including switchgrass, miscanthus and big bluestem are planted as a specialty biomass feedstock in Mountain Top Industrial Park.

The yield of poplar trees can be as high as 12 oven dry tons every year ("Populus," 2010). As biomass perennial grasses for ethanol, the yield of switchgrass can be $4-6$ tonnes per acre ("Panicum virgatum," 2010), the annual yield of miscanthus and blue stem can reach 10 tonnes per acre ("Miscanthus," 2010). These plants are versatile and adaptable plants, which also can be used for soil conservation.

\subsection{Bioretention \& Wetland Plant Palettes}

Many bioretentions and wetlands capture, transport and infiltrate stormwater runoff on the site. They are located along greenways, near parking spaces and in several low points in areas outside of the greenways. Vegetation within the bioretention and wetland systems should be planted to enhance the stormwater areas. They will create strongly recognized and productive wildlife corridors, helping to connect the fragmented landscape.

Dogwood, Nannyberry, Buttonbush, Willow, and Poplar trees would be excellent food and habitat sources for wildlife, effective biofiltrators and various fall colors provide aesthetic value to the site. Permanent sedges and grass species will help build the soil profile to allow for additional colorful forbs that attract pollinators necessary to ecosystem health. Forbs such as milkweed, aster species, and goldenrod species, have established on the site. Their presence should be extended throughout the stormwater system (Figure 53 \& Figure 54). A wide variety of species will promote the most biodiversity of insects, birds and other species visiting the site. A bioretention cross - section are shown in Figure 55.

Vegetation within wetland areas should be similar to what is proposed in the bioretention systems. Since the wetland type on site is temporary ponds with a central sedge meadow zone, many different upland and wet meadow species are chosen to thrive in particular soil moisture content and sun / shade regime because of their sensitivity to hydroperiod, hydrodynamics, nutrient availability and other environmental conditions. A wetland cross - section are shown in Figure 55. 


\begin{tabular}{|c|c|c|c|}
\hline \multicolumn{4}{|c|}{ TREES \& SHRUBS PLANT PALETTES } \\
\hline Common & Botanical & $\begin{array}{l}\text { Good Fall } \\
\text { Color }\end{array}$ & Comment \\
\hline \multicolumn{4}{|l|}{ Trees } \\
\hline Pine & Pinus species & & \multirow{3}{*}{$\begin{array}{l}\text { Prefers a dry, sandy soil with a low pH; } \\
\text { full sun }\end{array}$} \\
\hline White & P. strobus & & \\
\hline Red & P. resinosa & & \\
\hline Eastern Hemlock & Tsuga canadensis & & $\begin{array}{l}\text { Prefers cool, moist, well-drained soils; } \\
\text { full sun to partial shade }\end{array}$ \\
\hline Oak & Quercus species & & large trees; shade trees; full sun; \\
\hline Red & Q. rubra & $\bullet$ & prefers moist, well-drained, acidic soil; \\
\hline Chestnut & Q. prinus & $\bullet$ & wildlife food source; slow growing \\
\hline Maple & Acer species & & Good fall foliage color; full sun and partial \\
\hline Red & A. rubra & $\bullet$ & shade; prefers moist, acidic soil \\
\hline Sugar & A. saccharum & $\bullet$ & good lawn trees \\
\hline Birch & Betula species & & \\
\hline Yellow & B. alleghaniensis & $\bullet$ & Full sun; prefers moist, acidic soils \\
\hline River & B. nigra & & \\
\hline American Beech & Fagus grandifolia & $\bullet$ & $\begin{array}{l}\text { Full sun; prefers moist, well-drained, acidic } \\
\text { soil; shallow, wide root system }\end{array}$ \\
\hline Black Cherry & Prunus serotina & $\bullet$ & $\begin{array}{l}\text { Along highways; Full sun to part shade; } \\
\text { prefers deep, moist soil }\end{array}$ \\
\hline \multicolumn{4}{|l|}{ Shrubs } \\
\hline Rhododendron & Rhododendron species & & \multirow{4}{*}{$\begin{array}{l}\text { Full sun to light shade; } \\
\text { moist, cool acidic, well-drained soils }\end{array}$} \\
\hline Flame Azalea & R. calendulaceum & & \\
\hline rosebay & R. maximum & & \\
\hline PJM & R. PJM Hybrids & & \\
\hline \multicolumn{2}{|c|}{ American Winterberry Ilex verticillata } & $\bullet$ & Prefers wet acidic soils \\
\hline Dogwood & Cornus species & & \\
\hline Gray & C. racemosa & $\bullet$ & prefers a cool, moist, acidic soil; \\
\hline Flowering & C. florida & $\bullet$ & Full sun to partial shade \\
\hline Pagoda & C. alternifolia & & \\
\hline
\end{tabular}

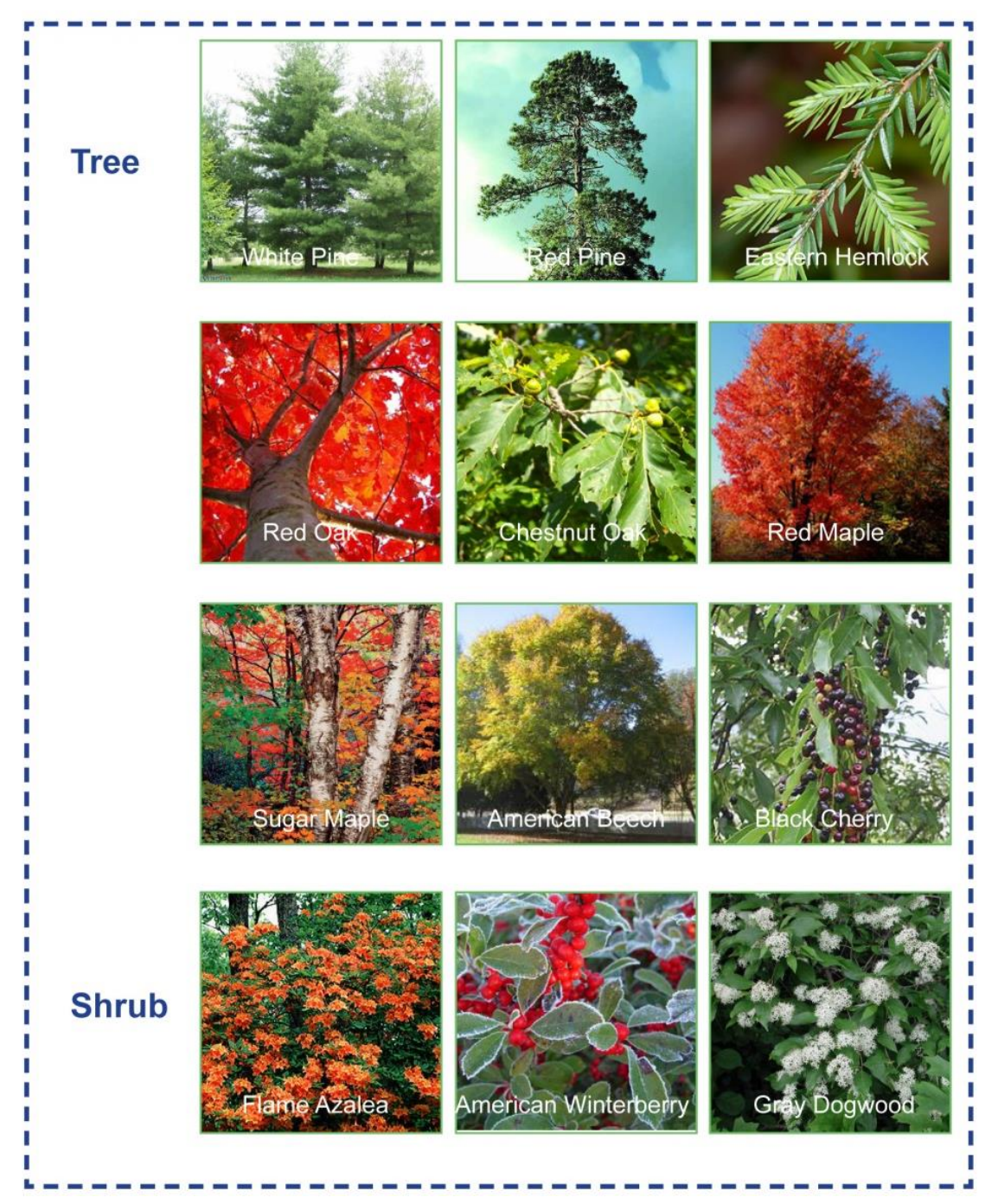

Figure 51. Trees \& Shrubs Plant Palettes 


\section{BIOMASS SPECIES PLANT PALETTES}

\begin{tabular}{|c|c|c|c|c|c|c|c|}
\hline & Name & Tree & Perennial & Height & Hardiness & Flower and Time & Comment \\
\hline Common & Botanical & Iree & Feremat & neigmt & Zone & & comitemt \\
\hline Switchgrass & Panicum virgatum & & $\bullet$ & $3-6^{\prime}$ & 4 to 9 & Golden fall color & Clump forming; four season interest; $4-6$ tons/acre \\
\hline Miscanthus & Miscanthus sinensis & & $\bullet$ & $6-10^{\prime}$ & 4 to 9 & Wind swept appearance & $\begin{array}{l}\text { Clump forming habit; tolerant of many soil conditions; } \\
\text { four season interest; } 5-15 \text { tons/acre }\end{array}$ \\
\hline & & & - & & & & $\begin{array}{l}\text { Tolerant of a wide range of soil conditions and moisture } \\
\text { levels; PH } 6.0 \text { - } 7.5 \text {; Used for erosion control in sand } \\
\text { and gravel pits, mine spoils, and roadsides; contributes }\end{array}$ \\
\hline Big bluestem & Andropogon gerardii & & & $5-7^{\prime}$ & 3 to 10 & Yellow seed heads & to diversified biomass production; \\
\hline Poplar trees & Populus & & & $50-165^{\prime}$ & 3 to 9 & $\begin{array}{l}\text { Pretty yellow blossoms } \\
\text { grow in clusters }\end{array}$ & $\begin{array}{l}\text { Fast growing; clean contaminated ground water; an } \\
\text { energy crop for biomass }\end{array}$ \\
\hline
\end{tabular}

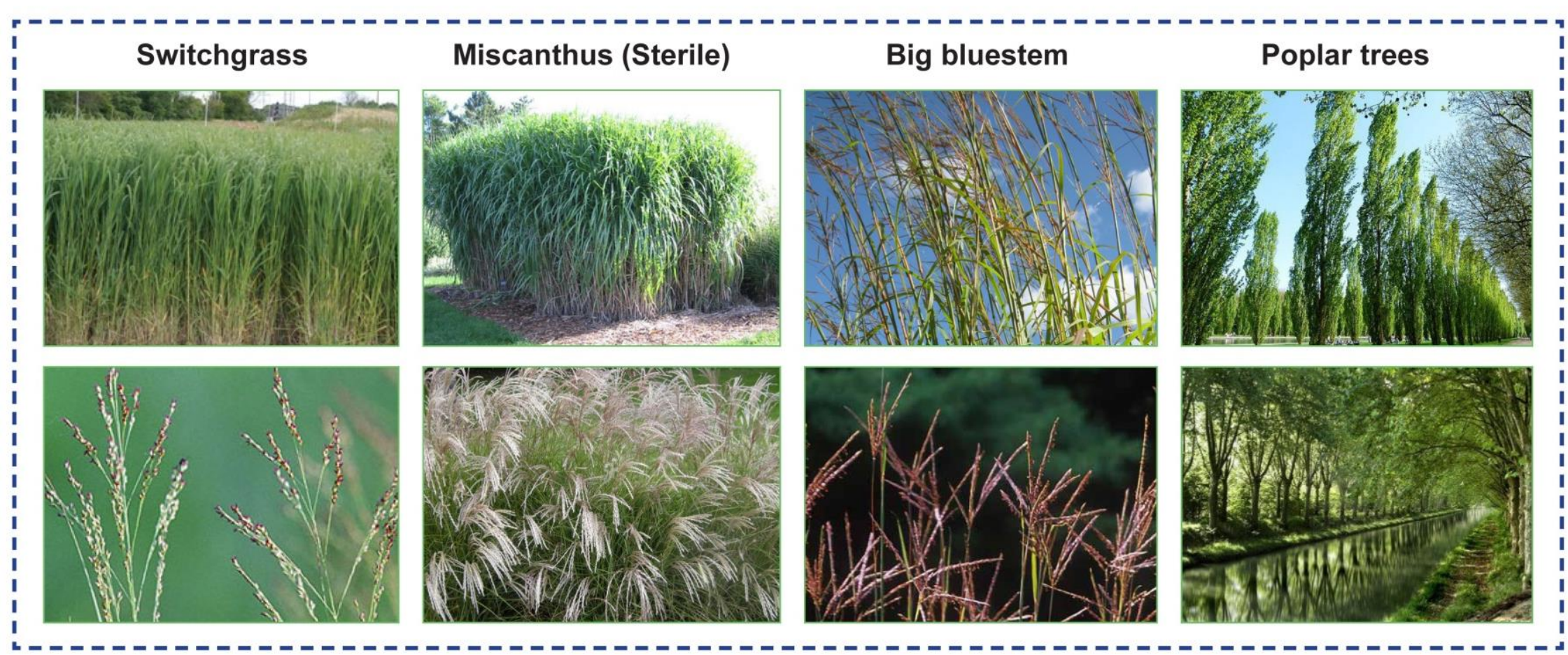

Figure 52. Biomass Species Plant Palettes 


\begin{tabular}{ll}
\hline & \\
BIORETENTION PLANT PALETTES \\
\hline Common Name & Botanical Name \\
\hline Stabilizing Shrubs & \\
Red-osier Dogwood & Cornus sericea \\
Nannyberry & Viburnum lentago \\
Buttonbush & Cephalanthus occidentalis \\
Sandbar Willow & Salix exigua \\
\hline & \\
Permanent Grasses/ Sedges & \\
Switch Grass & Panicum virgatum \\
Big Bluestem & Andropogon gerardii \\
Bristly Sedge & Carex comosa \\
Crested Oval Sedge & Carex cristatella \\
Bottlebrush sedge & Carex comosa \\
Brown Fox Sedge & Carex vulpinoidea \\
Virginia Wild Rye & Elymus virginicus \\
Fowl Manna Grass & Glyceria striata \\
Dark Green Rush & Scirpus atrovirens \\
Wool Grass & Scirpus cyperinus \\
\hline & \\
Forbs & \\
Water Plantain & Alisma spp. \\
Swamp Milkweed & Asclepias incarnata \\
New England aster & Aster novae-angliae \\
Tall Coreopsis & Coreopsis tripteris \\
Spotted Joe-Pye Weed & Eupatorium maculatum \\
Blue Flag & Iris virginica \\
Marsh Blazing Star & Liatris spicata \\
Cardinal Flower & Lobelia cardinalis \\
Great Blue lobelia & Lobelia siphilitica \\
Common Water Horehound & Lycopus americanus \\
Common arrowhead & Sagittaria latifolia \\
Blue Vervain & Verbena hastata \\
Golden Alexanders & \\
\hline
\end{tabular}

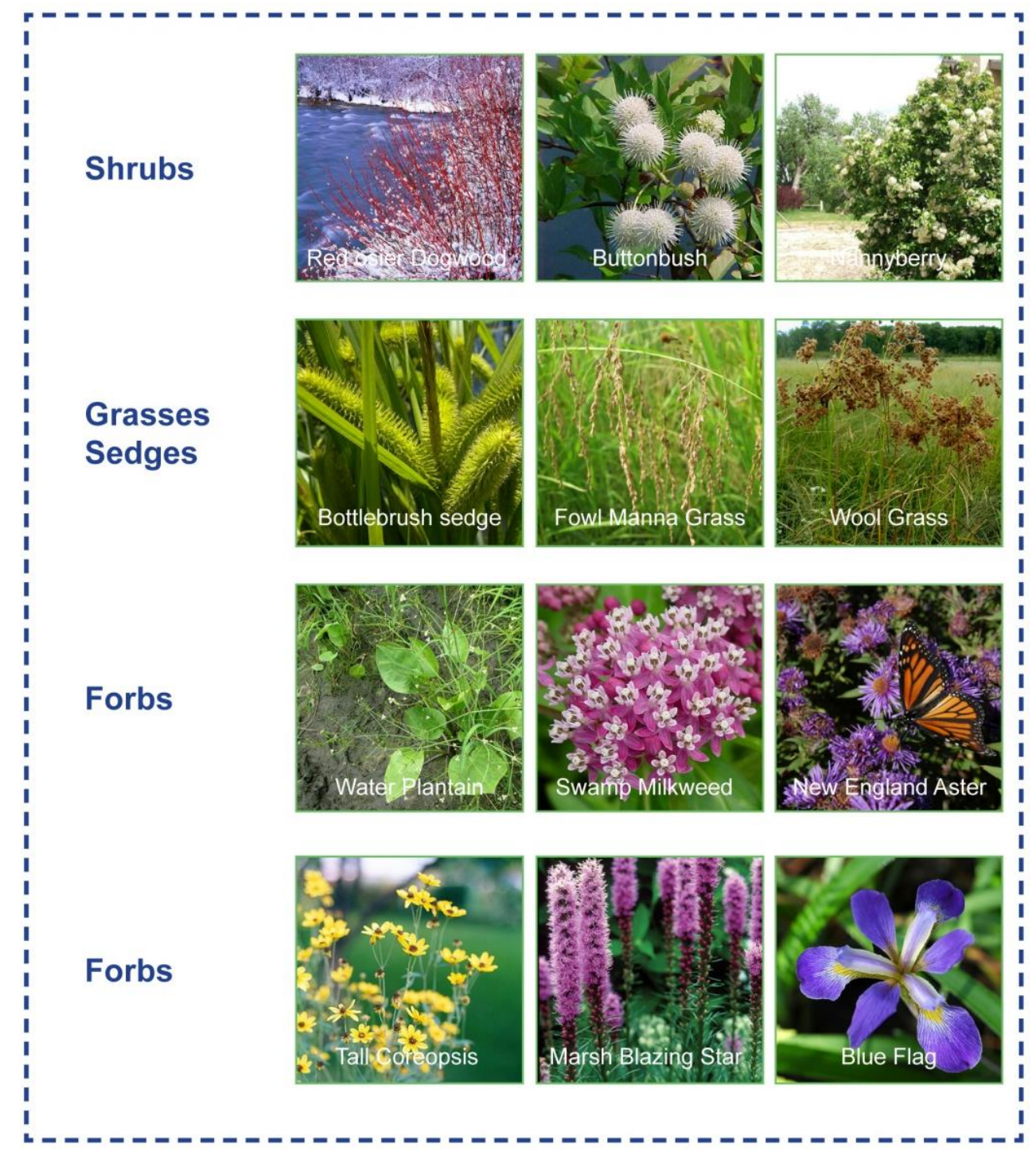

Figure 53. Bioretention Plant Palettes 


\section{WETL
Common Name \\ Wet Meadow}

Boneset

New England Aster

Marsh Blazing Star

\section{Upland and Prairie}

False Sunflower

False Blue Indigo

Switchgrass

Big Bluestem

Purple Coneflower

\section{Stabilizing Shrub}

Red-osier Dogwood

Nannyberry

Buttonbush

Sandbar Willow

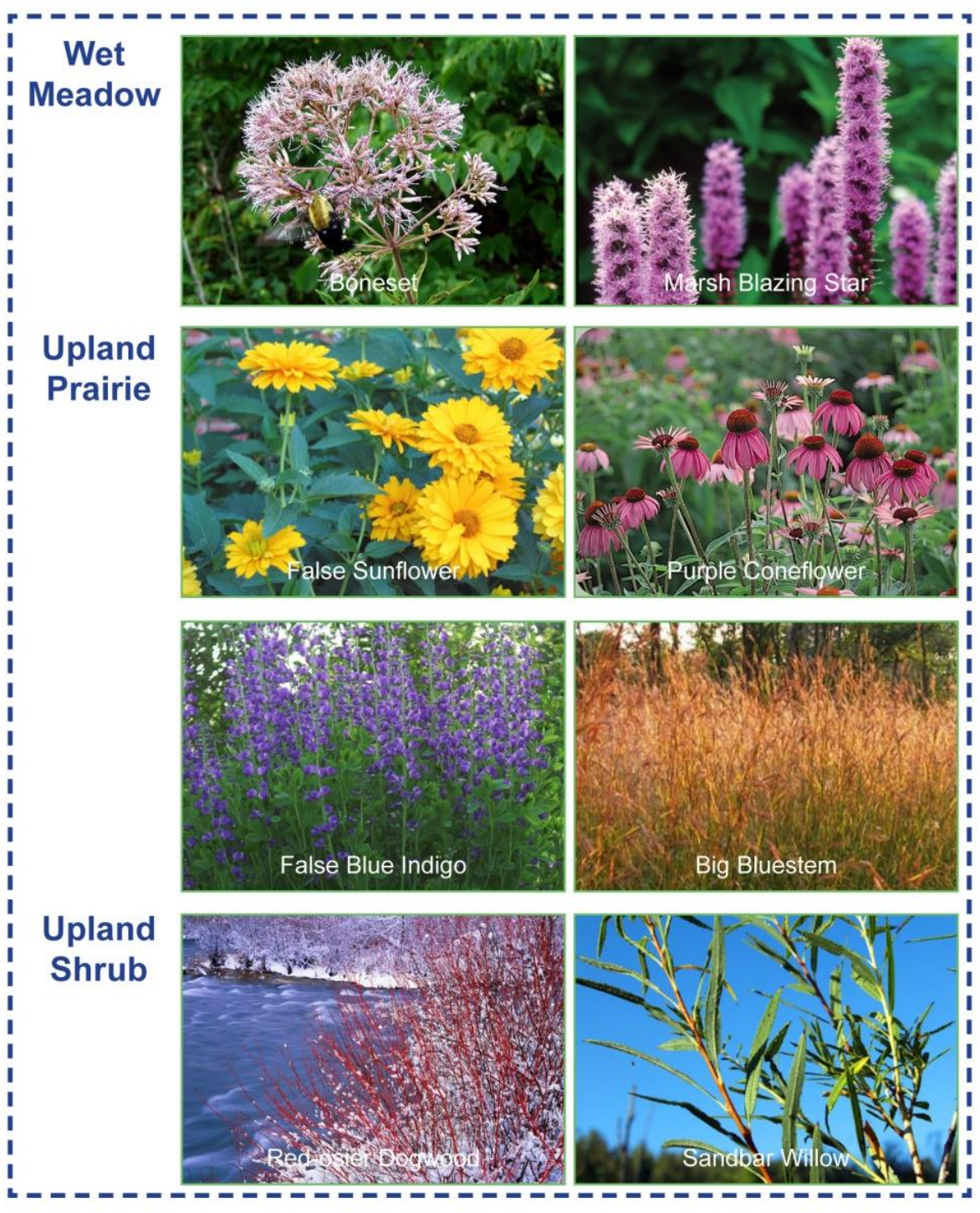

Figure 54. Wetland Plant Palettes

-

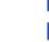

I

i

-

-

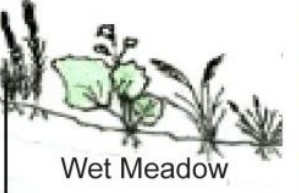

Cephalanthus Occidentalis

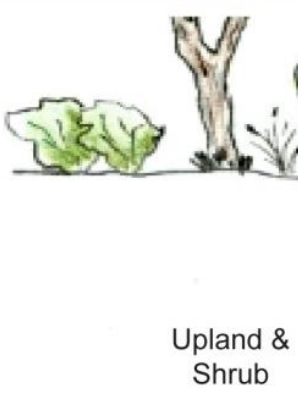

Heliopsis Helianthoides

Baptisia australis

Panicum virgatum

Andropogon gerardii

False blue indigo

\section{Cornus Sericea}

Viburnum Lentago Salix Exigua

Eupatorium perfoliatum

Aster novae-angliae

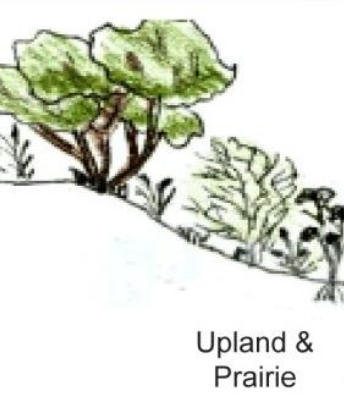




\section{Bioretention AA' Section}
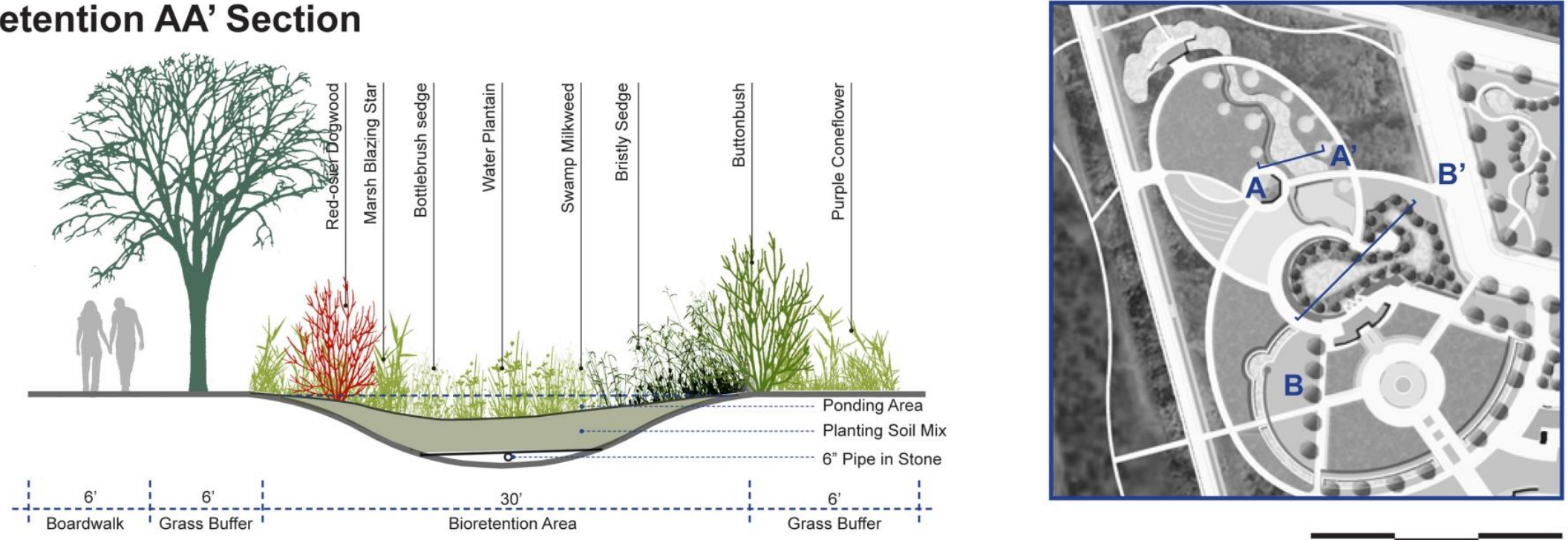

Wetland BB'Section

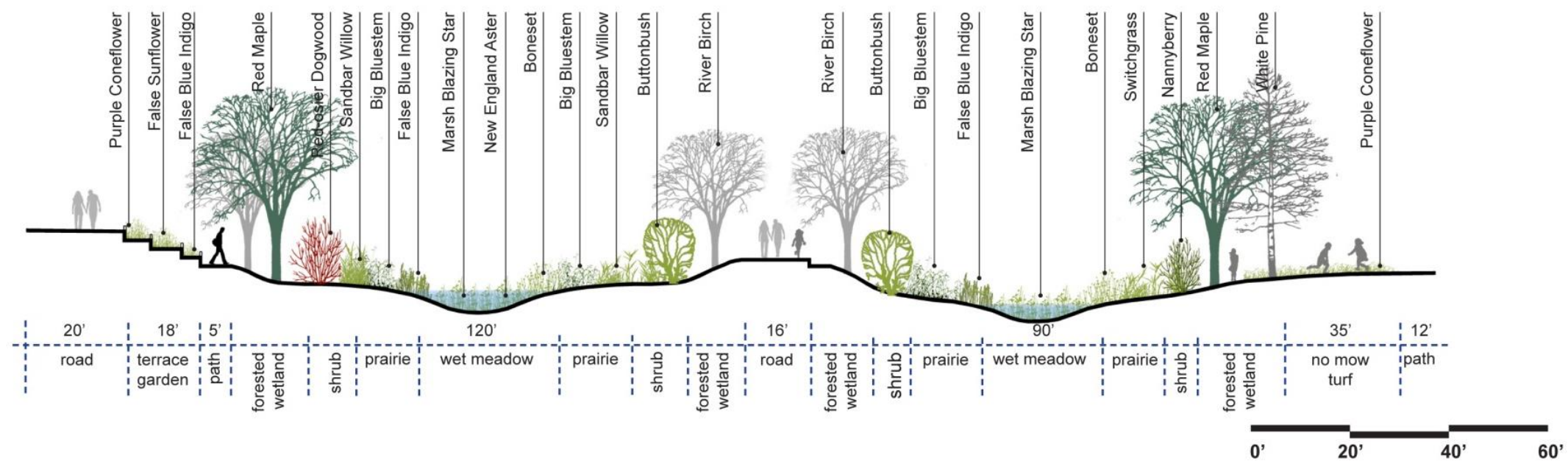

Figure 55. Bioretention Section \& Wetland Section 


\section{References}

. AWS Truepower. (2010) West Virginia Wind Data.

. Beaver Creek - Headwaters along Rte. 93 to Blackwater River. (1999) Retrieved November, 2013, from http://www.americanwhitewater.org/content/River/detail/id/4313/

. Blackwater Wildlife Management Area. (2004) Retrieved November, 2013, from http://www.wvexp.com/index.php/Blackwater Wildlife Management Area

. Build where Industry Thrives. (2011) Retrieved November, 2013, from http://www.taiganova.com/

. Canaan Valley National Wildlife Refuge. (2013) Retrieved November, 2013, from http://en.wikipedia.org/wiki/Canaan Valley National Wildlife Refuge

Ciolkosz, D. (2010). Renewable and Alternative Energy Fact Sheet. College of Agricultural Sciences \& Agricultural Research and Cooperative Extension: Pennsylvania State University.

. Clean Energy: The Basics - Montgomery County MD. (2012) Retrieved November, 2013, from http://www6.montgomerycountymd.gov/dectmpl.asp?url=/Content/dep/energy/CleanEnergyBasics.asp

Galatowitsch, S. M., \& Valk, A. (1994). Restoring prairie wetlands: an ecological approach: lowa State University Press.

. Grant County, West Virginia. (2013) Retrieved November, 2013, from http://en.wikipedia.org/wiki/Grant County, West Virginia

. Green Roof -- System Types. (2003) Retrieved January, 2014, from https://www.albemarle.org/department.asp?department=water\&relpage=4092

. A Green Sponge for a Water-Resilient City: Qunli Stormwater ParkHaerbin City, Heilongjiang Province, China.

(2012) Retrieved November, 2013, from http://www.asla.org/2012awards/026.html

Levy, L. (1997). Peter Walker: minimalist gardens: Spacemaker Press.

. Miscanthus. (2010) Retrieved January, 2014, from http://en.wikipedia.org/wiki/Miscanthus

. Monongahela National Forest. (2013) Retrieved November, 2013, from http://en.wikipedia.org/wiki/Monongahela National Forest

. Mount Storm Lake. (2013) Retrieved November, 2013, from http://en.wikipedia.org/wiki/Mount Storm Lake

. Mount Storm Power Station. (2013) Retrieved November, 2013, from https://www.dom.com/about/stations/fossil/mount-storm-power-station.jsp

. Mount Storm, WV. (2012) Retrieved November, 2013, from http://en.wikipedia.org/wiki/Mount Storm, WV

. Mountaintop removal mining. (2013) Retrieved November, 2013, from http://en.wikipedia.org/wiki/Mountaintop removal mining

. National Renewable Energy Laboratory. (2011) 2010 Wind Technologies Market Report.

. The official Site of Blackwater Falls State Park. (2009) Retrieved November, 2013, from http://www.blackwaterfalls.com/

. Panicum virgatum. (2010) Retrieved January, 2014, from http://en.wikipedia.org/wiki/Switchgrass

. Populus. (2010) Retrieved January, 2014, from http://en.wikipedia.org/wiki/Poplar

. Portland's Green Infrastructure: Quantifying the Health, Energy, and Community Livability Benefits. (2010).

Risch, C. (2013). Sustainable Energy Parks on Mine-Scarred Lands in Appalachia.

. River - Friendly Landscping. (2011) Retrieved November, 2013, from http://www.msa.saccounty.net/sactostormwater/RFL/about.asp

. Solar power in West Virginia. (2013) Retrieved November, 2013, from http://en.wikipedia.org/wiki/Solar power in West Virginia

. STATS America. Retrieved November, 2013, from http://www.easybib.com/cite/form

. Surface mining. (2013) Retrieved November, 2013, from http://en.wikipedia.org/wiki/Surface mining

. Upper Potomac Coalfield. Retrieved November, 2013, from

http://www.coalcampusa.com/nowv/potomac/potomac.htm 
. Virginia DCR Stormwater Design Speification No. 9 Bioretention. (2011).

Wang, J., Grushecky, S., \& McNeel, J. (2007). Biomass Resources, Uses, and Opportunities in West Virginia.

. Welcome to Pushpa Gujral Science City. (2012) Retrieved November, 2013, from http://www.pgsciencecity.org/energypark.htm

. West Virginia Corridor H. (2003) Retrieved November, 2013, from http://www.wvcorridorh.com/

Yacobucci, B. D., \& Schnepf, R. (2007). Ethanol and Biofuels: Agriculture, Infrastructure, and Market Constraints Related to Expanded Production. 